\title{
5.2
}

\section{Continental Atlantic Rivers: the Seine Basin}

Josette Garnier ${ }^{1}$, Michel Meybeck ${ }^{1}$, Sophie Ayrault ${ }^{2}$, Gilles Billen ${ }^{1}$, Hélène Blanchoud ${ }^{1}$, Catherine Carré ${ }^{3}$, Nicolas Flipo ${ }^{4}$, Johnny Gasperi ${ }^{5}$, Laurence Lestel ${ }^{1}$, Ghislain de Marsily ${ }^{1}$, Jean-Marie Mouchel ${ }^{1}$, Pierre Servais ${ }^{6}$, Evelyne Tales ${ }^{7}$

${ }^{1}$ SU CNRS EPHE UMR 7619 Metis, Paris, France; ${ }^{2}$ CEA CNRS UVSQ UMR 8212 LSCE/IPSL, Gif-sur-Yvette, Cedex, France; ${ }^{3}$ University Paris I Pantheon-Sorbonne, UMR 7533 LADYSS, Paris, France; ${ }^{4}$ Centre de Géosciences, Mines ParisTech, PSL Research University, Fontainebleau, France; ${ }^{5}$ University Paris-Est, LEESU, Créteil, Cedex, France;

${ }^{6}$ University Libre de Bruxelles, ESA, Bruxelles, Belgium; ${ }^{7}$ Inrae, UR HYCAR, Antony, France

\section{O U T L I N E}

\subsubsection{Introduction}

5.2.2 Historical perspective

5.2.3 Geological and hydrological context

5.2.4 Modeling tools for the Seine River basin

5.2.4.1 Modeling surface water quality

5.2.4.2 Groundwater modeling and its coupling with surface waters

292

295

295

295

296

298

5.2.5 Water chemistry and chemical contamination 298

5.2.5.1 Maximum pollution stage established on natural backgrounds of ions and heavy metals

5.2.5.2 Urban pollution: water quality variables and modeling in the lower Seine

5.2.5.3 Regulated organic pollutants: river water, particles, and fish contamination

5.2.5.4 Sediment archives

5.2.5.4.1 Inorganic pollutants

5.2.5.4.2 Particulate organic pollutants

5.2.5.5 Emerging pollution

5.2.5.5.1 Alkylphenol polyethoxylates and bisphenol A: differences in their origins

5.2.5.5.2 Pharmaceuticals: variable persistence in the river
5.2.5.5.3 Perfluorinated alkylated substances: a point source origin

5.2.5.5.4 Plastic debris: first analyses 306 5.2.5.5.5 Antimony, silver, and thallium 307

5.2.5.6 Pesticide contamination: the barrel of the Danaids

5.2.6 Biodiversity, biological compartments

5.2.6.1 Microbiological contamination: a pronounced decline in the last 2 decades 308

5.2.6.1.1 Diffuse and point sources of microbiological contamination 309

5.2.6.1.2 Microbiological water quality in the Seine River over one century

5.2.6.1.3 Pathogenic microorganisms

5.2.6.1.4 Modeling microbiological contamination in the Seine River drainage network

5.2.6.2 Heterotrophic and autotrophic bacteria, and oxygen patterns in the lower Seine

5.2.6.2.1 Heterotrophic bacteria and organic matter degradation

5.2.6.3 Aquatic vegetation

5.6.3.1 Phytoplankton

5.2.6.3.2 Macrophytes 


\begin{tabular}{|c|c|c|c|c|c|c|c|}
\hline & & 5.2.6.3.3 Periphyton & 312 & & & 5.2.7.4.2 Preventive measures & 317 \\
\hline & 5.2 .6 .4 & Microfauna & 312 & & & & \\
\hline & 5.2 .6 .5 & $\begin{array}{l}\text { Fish and their historical evolution: } \\
\text { controlling factors }\end{array}$ & 313 & 5.2 .8 & $\begin{array}{l}\text { Human } \\
\text { manager }\end{array}$ & $\begin{array}{l}\text { impact, conservation, and } \\
\text { ment }\end{array}$ & 318 \\
\hline & & $\begin{array}{l}\text { 5.2.6.5.1 General historical evolution } \\
\text { 5.2.6.5.2 Temporal and spatial fish }\end{array}$ & 313 & & 5.2 .8 .1 & $\begin{array}{l}\text { The } 1964 \text { Water Law: a turning point in } \\
\text { river management }\end{array}$ & 318 \\
\hline & & $\begin{array}{l}\text { assemblage changes } \\
\text { 5.2.6.5.3 Fish dynamics in the upper }\end{array}$ & 314 & & 5.2 .8 .2 & $\begin{array}{l}\text { Flood control and river regime } \\
\text { modification }\end{array}$ & 319 \\
\hline & & Seine River floodplain (Bassée) & 314 & & 5.2 .8 .3 & Water quality management and the & \\
\hline 5.2 .7 & Biogeoc & hemistry: nutrients and & & & & wastewater treatment & 319 \\
\hline & $\begin{array}{l}\text { eutroph } \\
5.2 .7 .1\end{array}$ & $\begin{array}{l}\text { ication } \\
\text { Eutrophication in the Seine basin: }\end{array}$ & 314 & & 5.2 .8 .4 & $\begin{array}{l}\text { Assessing, reporting and declaring river } \\
\text { water quality: a social construction }\end{array}$ & 320 \\
\hline & & $\begin{array}{l}\text { successful P reduction from urban } \\
\text { sources }\end{array}$ & 314 & & 5.2 .8 .5 & $\begin{array}{l}\text { Trajectories of river quality issues in the } \\
\text { Seine River basin }\end{array}$ & 321 \\
\hline & 5.2 .7 .2 & Climate change impacts & 315 & & 5.2.8.6 & Conservation and restoration measures & \\
\hline & 5.2 .7 .3 & Nitrogen contamination & 315 & & & in aquatic ecosystems & 322 \\
\hline & & 5.2.7.3.1 Contamination in the basin & 315 & & & 5.2.8.6.1 Protection of aquatic habitats & 322 \\
\hline & & $\begin{array}{l}\text { 5.2.7.3.2 Nitrate input to coastal zones } \\
\text { and its consequences for marine }\end{array}$ & & & & $\begin{array}{l}\text { 5.2.8.6.2 Restoration of habitats and } \\
\text { ecological continuity }\end{array}$ & 322 \\
\hline & 5.2.7.4 & $\begin{array}{l}\text { eutrophication } \\
\text { Scenarios to improve nutrient-related }\end{array}$ & 316 & & & 5.2.8.6.3 Migratory fish & 322 \\
\hline & & $\begin{array}{l}\text { water quality in the river and its coastal } \\
\text { zone }\end{array}$ & 317 & 5.2 .9 & Conclus & sions and lessons learnt & 323 \\
\hline & & 5.2.7.4.1 Curative measures & 317 & Refere & ences & & 324 \\
\hline
\end{tabular}

\subsubsection{Introduction}

The emergence of the river continuum concept (Vannote et al., 1980) allowed a stepwise enlargement of river ecology, where the drainage network and stream order organization were considered as a whole, with predictable longitudinal patterns of geomorphological-hydrological conditions and responses of biological communities along the gradient from headwaters to estuaries. Vertical and lateral interactions of rivers with aquifers, riparian wetlands (Haycock et al., 1993; Vought et al., 1994), and connected stagnant annexes, such as dead zones and reservoirs (Ward and Stanford, 1983; Reynolds et al., 1994), later were recognized as important factors in the ecological and biogeochemical functioning of hydrosystems.

The hydrosystem is closely linked to the functioning of waterscapes and terrestrial systems forming the watershed, which control the amount of water flowing through it as well as its chemical composition; it has been gradually shaped and exploited over historical periods, that is, centuries to millennia for Western European rivers such as the Seine. Similarly, the future trajectory of river systems will be dictated by the complex political/social processes by which society modifies, intentionally or unintentionally, its environment, taking into account the past heritage of these modifications.

The link between watershed management and the response of hydrosystems is far from straightforward, especially because of the long-term inertia of some system compartments. This is demonstrated in the Seine River basin for arable soils, which can accumulate considerable stocks of phosphorus and carbon due to past agricultural practices (Martin et al., 2011; Le Noë et al., 2018a), as well as for large aquifers with longterm hydrological residence, whose composition still reflects constraints dating back at least $30-50$ years (Ledoux et al., 2007). This complexity is also true for large urban infrastructures, such as those established for Paris' wastewater collection and treatment, which can hinder the development of more sustainable solutions, as well as for institutions, whose division of skills can sometimes inhibit innovative rethinking of the system (Bouleau and Fernandez, 2012).

With the coexistence of the large Paris conurbation with highly productive agriculture, the Seine watershed offers an outstanding example of complex interactions between societal and biophysical processes. 

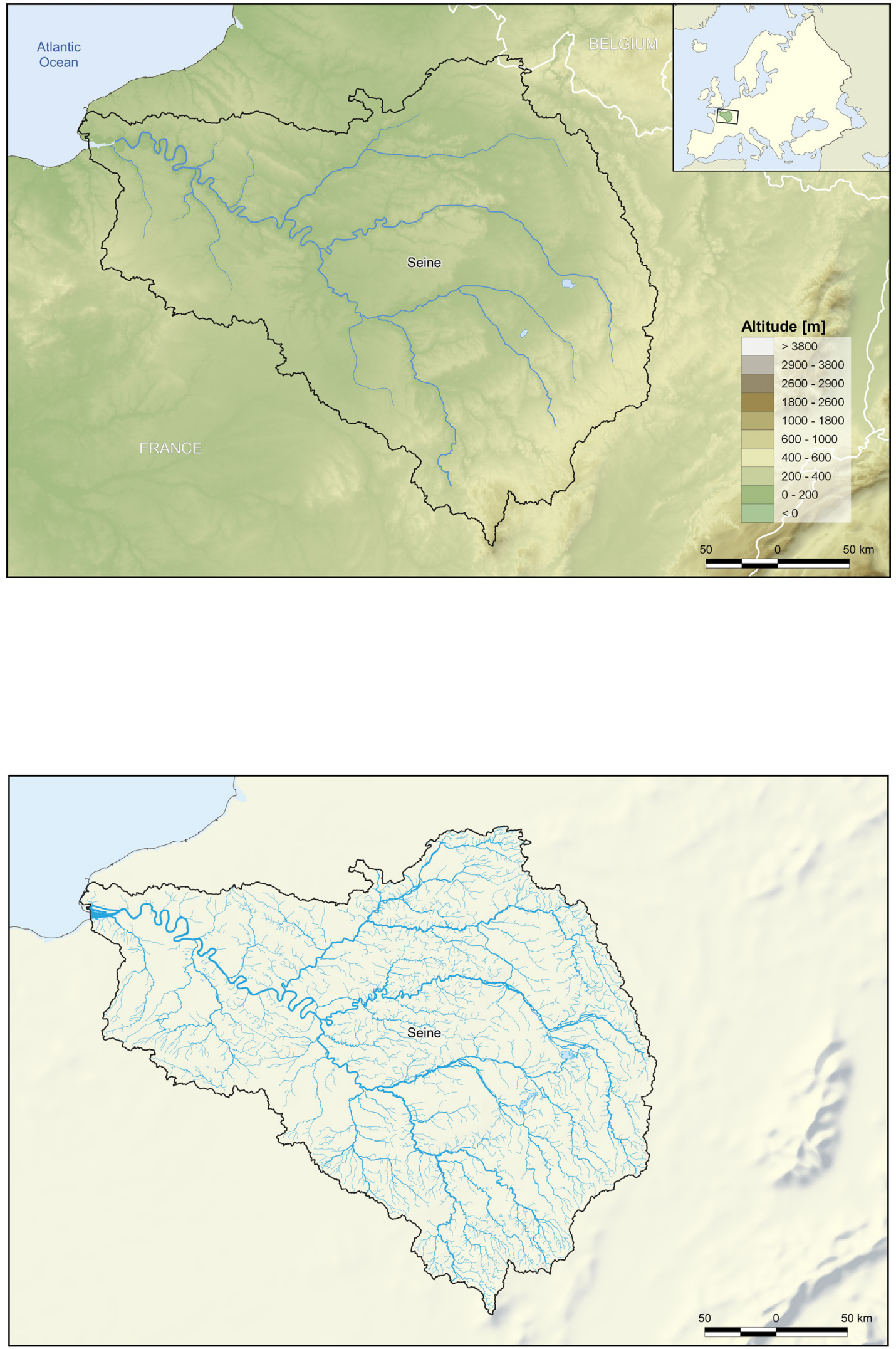

Digital elevation model (upper panel) and drainage network (lower panel) of the Seine River basin. 


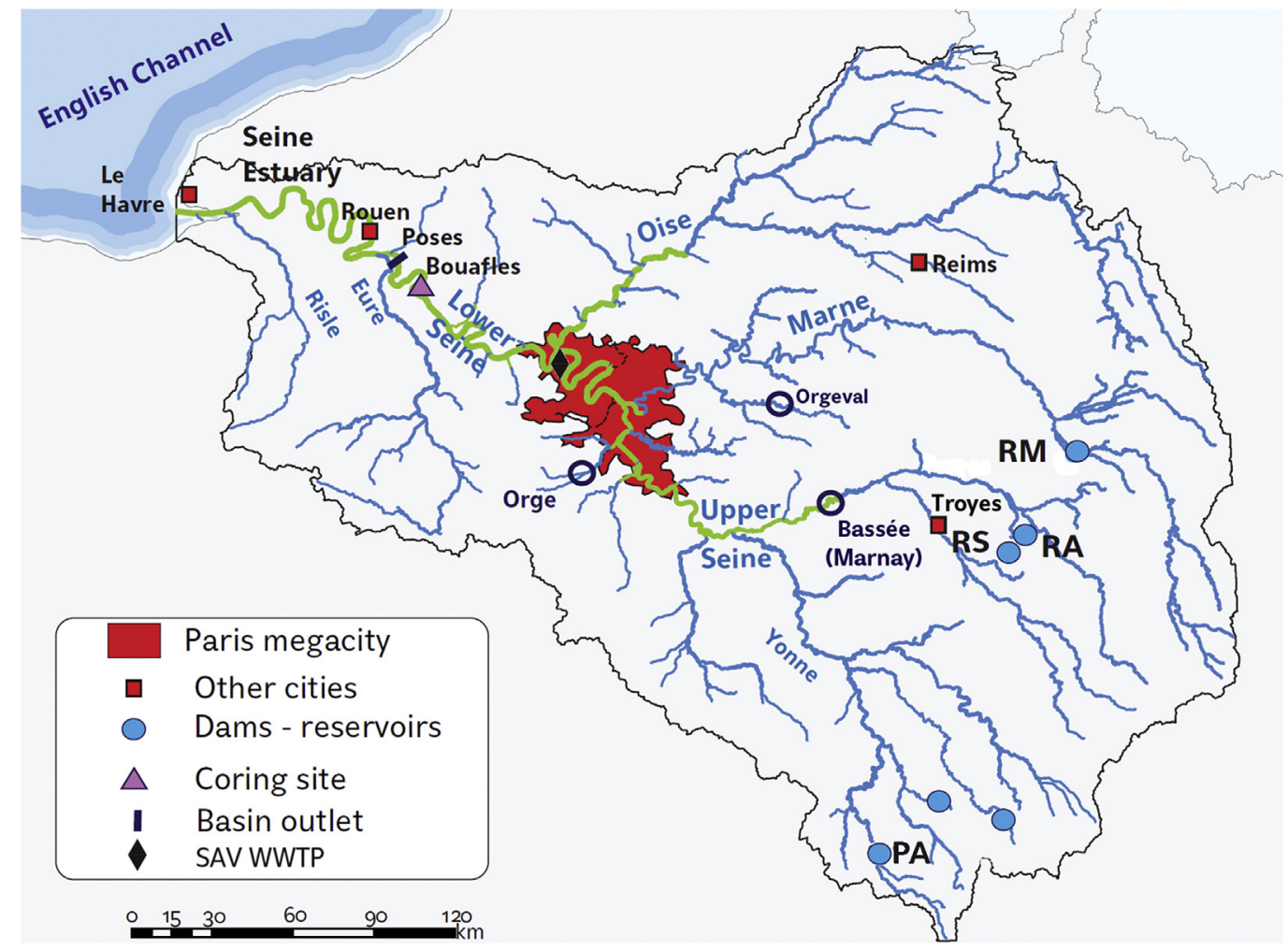

FIGURE 5.2.1 The Seine River basin and its main tributaries. PA, Pannecières reservoir in Morvan; RA, Reservoir-Aube; RM, Reservoir-Marne; $R S$, Reservoir-Seine. Other main study sites: Bassée: main alluvial wetland on the upper Seine, Marnay being a reference river station in the area. Poses: estuarine limit. Bouafles: main coring site for basin outlet. Orge: urban river. Orgeval: crop-dominated subbasin.

One of the largest megacities in Europe (ca. $12 \mathrm{M}$ inhabitants), Paris has developed near the confluence of three major tributaries (see map and Fig. 5.2.1), the Marne, upper Seine (i.e., from the Marne-Seine confluence to the Seine-Yonne confluence), and Oise River; a situation that was once a favorable factor for longdistance transport of food, timber, and construction material. However, the Seine River discharge with its yearly average of $\sim 500 \mathrm{~m}^{3} / \mathrm{s}$ at the last gauging station before the estuary, where it meets the Eure tributary, is rather limited. Compared to wastewater inputs $\left(30 \mathrm{~m}^{3} / \mathrm{s}\right)$, low flows in Paris at natural conditions are only $50 \mathrm{~m}^{3} / \mathrm{s}$. The current population is mostly concentrated in the central part of the basin within the Paris conurbation and downstream along the Lower Seine, linking the city to the estuary and its major harbor infrastructures at Rouen and Le Havre (Fig. 5.2.1). The urbanized part of the basin is constantly growing. Paris conurbation contains 12.4 million inhabitants out of the 16.7 million inhabitants within the basin. Along urban tributaries in the Paris region, the population density ranges between 1000 and 5000 inhabitants per $\mathrm{km}^{2}$ (inhab $/ \mathrm{km}^{2}$ ) while in the headwaters it is much lower ( $<20$ inhab/ $\mathrm{km}^{2}$ ) and concentrated along the main rivers.
Paris is surrounded by one of the most productive and specialized agricultural areas in the world, oriented toward the mass production of cereal and industrial crops. A large part of this production is exported every year by river transport. Only the peripheral eastern and western areas of the basin have kept significant livestock farming activities, after major land-use changes that mostly occurred in the second half of the 20th century (Mignolet et al., 2007; Le Noë et al., 2018b), a major socio-ecological transition of the Seine system.

The PIREN-Seine (https://www.piren-seine.fr/), a large interdisciplinary research program in which chemists, hydrologists, biologists, and agronomists dialogue with sociologists, geographers, and historians on the Seine River system, was created and jointly funded in 1989 by the French CNRS and Water Authorities of the Seine basin. Its aims are to improve the understanding of the dynamics of the river system, to provide tools for better management and to explore possible future scenarios. This chapter summarizes the main results obtained by the participants of this 30 -year-old scientific project, which is still active today. 


\subsubsection{Historical perspective}

The morphology and hydrology of the river network have been deeply affected by the urban growth of Paris and land-use changes over the last 150 years. Tile drainage, the removal of wetlands, and recalibration of small streams (orders 1-2; Strahler, 1957) peaked in the 1960s and deeply affected the hydrology and biogeochemistry of headwaters (Billen and Garnier, 2000; Sebilo et al., 2003). As well, thousands of small ponds were filled and converted to cropland (Passy et al., 2013), affecting mid-size streams (orders 2-4). The largest river reaches (orders 5-8) were gradually modified by navigation infrastructure such as dams and locks from the late 19th century into the 1970s that maintained a constant water level throughout the year (Mouchel et al., 1998). Between 1974 and 1991, the construction of three large reservoirs (totalling $750 \mathrm{Mm}^{3}$ ) aimed to regulate floods and sustain low waters (Garnier et al., 1999, 2000) and raised the total storage capacity of reservoirs in the Seine to $880 \mathrm{Mm}^{3}$ (Fig. 5.2.1). After 1950, the estuary underwent consequential management practices, dredging, and channel maintenance that strongly modified its morphology and jeopardized its biogeochemical role as a filter for nutrients delivered to the coast (Garnier et al., 2010).

Urban pollution generated by the city of Paris, then by the Parisian conurbation, impacted the lower Seine and estuary and has been a major concern of authorities for over a century (Barles and Guillerme, 2014; Lestel and Carré, 2017). Water quality was substantially degraded in terms of oxygen levels, ammonia, nitrite, and fecal bacteria over a river reach of $100-250 \mathrm{~km}$ downstream of Paris (see below). The first method for wastewater treatment was spreading sewage over farm fields, an innovation arriving in the 1880s. Some of these sites were eventually converted into wastewater treatment plants (WWTPs). However, the agricultural fields were never sufficient for the volume of sewage generated by Paris (see management section). The lag between sewage collection and adequate treatment was only bridged in the 1990s (Meybeck et al., 2018) when sufficient WWTPs were installed, corresponding to a sewage collection and treatment efficiency approaching $98 \%$.

\subsubsection{Geological and hydrological context}

The Seine basin, including the estuary, extends over $76,238 \mathrm{~km}^{2}\left(48^{\circ} 53^{\prime} \mathrm{N}, 2^{\circ} 13^{\prime} \mathrm{E}\right)$. Ninety-seven percent of its area lies within the sedimentary Paris basin, a major French geological region (Triassic to Tertiary). Basin lithology is a composite of carbonate (69.6\%), sandy formations (13.6\%), interbedded by poorly permeable clay and marl units $(9 \%)$ covered by alluvial deposits $(5.4 \%)$, the rest being crystalline bedrock (Guillocheau et al., 2000). The alternating limestone, clay, and sandstone units are covered by carbonated loess in western and central parts (Guerrini et al., 1998). Except for the eastern ridge of the basin that lies on Morvan crystalline bedrock over $2000 \mathrm{~km}^{2}$, the relief is gentle with a median elevation of $150 \mathrm{~m}$ asl. The Seine is a typical lowland river with low erosion and turbidity.

The hydrological regime of the Seine is pluvial/ oceanic. Mean rainfall in the basin is $800 \mathrm{~mm} / \mathrm{yr}$ with some spatial variability; for example, a maximum around $1200 \mathrm{~mm} / \mathrm{yr}$ along the coast and only $650 \mathrm{~mm} / \mathrm{yr}$ in the central Morvan region (Quintana-Seguí et al., 2008; Vidal et al., 2010). Rainfall exhibits little seasonality so that the flow seasonal variation derives from evapotranspiration resulting in winter high flows and summer low flows naturally sustained by many sedimentary aquifers and by large reservoirs for the upper and middle Seine and Marne rivers. For instance, Seine discharge at the last gauging station before the estuary, Poses (see Fig. 5.2.1), has on average $485 \mathrm{~m}^{3} / \mathrm{s}$ but reaches $2280 \mathrm{~m}^{3} / \mathrm{s}$ in winter and $80 \mathrm{~m}^{3} / \mathrm{s}$ in summer over the last 50 years. In addition, a 17-year cycle associated with the North Atlantic Oscillations causes long-term temporal variability inflow (Massei et al., 2010) as well as groundwater levels (Flipo et al., 2012). Therefore variability in hydroclimatic signals requires calculations averaged over a long period of time, $>17$ years. The total length of the river network is $22,051 \mathrm{~km}$, mostly composed of first- and second-order streams $(10,688$ and $4488 \mathrm{~km}$, respectively) (Tables 5.2.1 and 5.2.2).

Connectivity of the river network with the underlying aquifer system is defined by stratigraphic relationships related to gravel deposits comprising the hydraulic corridor of the river, which were established during the Weichselian Stage (120,000-10,000 years BP). Four subsystems are defined: incised (in some headwaters), stable (plateau headwaters), aggraded (large alluvial plains), and encased (large alluvial plains that contain highly variable geomorphologic and grain-size facies with medium to gentle longitudinal slopes) (Curie et al., 2007). The river network density depends on the slope and type of underlying geological unit, with the lower network density over the chalk aquifer unit covering $22 \%$ of the basin area and the highest on claymarl lithology (9\%). Wetlands are mostly located at the stream-aquifer interface and in large alluvial systems. Potentially, $10 \%-15 \%$ of the basin surface can correspond to wetland areas (Curie et al., 2007), which display the basin's substantial potential to restore its ecological function. The current extent of active wetlands is only $6 \%$ (Billen et al., 2018a).

\subsubsection{Modeling tools for the Seine River basin}

Modeling the hydrological, sedimentary, biogeochemical functioning is one objective of the 30-year study of the Seine River, taking into account human 
TABLE 5.2.1 General characterization of the Seine River basin.

\begin{tabular}{ll}
\hline & Seine river \\
\hline Mean catchment elevation $(\mathrm{m})$ & 150 \\
Catchment area* $\left(\mathrm{km}^{2}\right)$ & 76,285 \\
Mean discharge $\left(\mathrm{km}^{3} /\right.$ year $)$ & $16.7(30 \mathrm{yrs}$ 1978-2017) \\
Mean precipitation $(\mathrm{cm} /$ year $)$ & 76 \\
Mean air temperature $\left({ }^{\circ} \mathrm{C}\right)$ & 10.6 \\
Number of ecological regions & 2 \\
\hline Land use $(\%$ of catchment) & \\
\hline Urban & 7.3 \\
Arable & 53 \\
Pasture & 13 \\
Forest & 24.6 \\
Natural grassland & 0.1 \\
Sparse vegetation & 0.9 \\
Wetland & 0.1 \\
Freshwater bodies & 0.7 \\
Protected area $(\%$ of catchment $)$ & 0.3 \\
\hline
\end{tabular}

Water stress

\begin{tabular}{ll}
\hline Number of large dams $(>15 \mathrm{~m})$ & 3 \\
Total reservoir volume ${ }^{* *}\left(10^{6} \mathrm{~m}^{3}\right)$ & 880 \\
Native fish species & 30 \\
Nonnative fish species & 23 \\
Large cities $(>100,000)$ & 8 \\
$\begin{array}{l}\text { Human population density } \\
\left.\text { (people/ } \mathrm{km}^{2}\right)\end{array}$ & 230 \\
$\begin{array}{l}\text { Annual gross domestic product } \\
(\$ \text { per person) }\end{array}$ & 51,700 \\
\hline
\end{tabular}

*Total surface area, the Seine estuary.

**Total volume for small and large reservoirs.

activities in the basin. This is done through a complex cascade of interconnected models that is continuously evolving. In addition to synthesizing all the knowledge gained, these modeling tools make it possible to explore scenarios, and results are used as a guide for managers.

\subsubsection{Modeling surface water quality}

There are currently two major clusters of models (Fig. 5.2.2) that aim to simulate the general hydrological and ecological functioning of the river, suspended sediment load, primary and secondary production, heterotrophic activity, and related major water quality parameters such as dissolved oxygen (DO), dissolved organic carbon, particulate organic carbon, ammonia $\left(\mathrm{NH}_{4}\right)$, nitrite $\left(\mathrm{NO}_{2}\right)$, nitrate $\left(\mathrm{NO}_{3}\right)$, orthophosphate $\left(\mathrm{PO}_{4}\right)$, total $\mathrm{P}$, and dissolved silica (DSi). Both clusters use the same ecological relationships and parameters, mathematically formalized in the RIVE model (e.g., phytoplankton growth, bacterial activity, sediment transport), which summarizes the results of 30 years of laboratory and field studies in the Seine basin (see references and www.fire.upmc.fr/rive for further details). The clusters mainly differ in their temporal and spatial resolution, and relation with hydrology and river hydraulics.

The RIVE model describes the dynamics of nutrients and microorganisms, including several types of bacteria and organic matter, and three groups of phytoplankton (chlorophyceae, cyanobacteria, diatoms) that differ in silica, nitrogen, and phosphorus requirements, a key for understanding eutrophication based on nutrient stoichiometry (Garnier et al., 1995, 2002; Billen et al., 2001; Garnier and Billen, 2007). A specific periphyton module also was implemented in RIVE (Flipo et al., 2004), allowing for the quantification of benthic versus pelagic processes (Flipo et al., 2007b; Thouvenot et al., 2007; Thouvenot-Korppoo et al., 2009). The RIVE model was encapsulated in two hydrogeomorphological/sedimentary models, illustrating the specificity of the Riverstrahler and ProSe models. It has continuously been enriched in new processes and parametrizations since the 1990s (e.g., Aissa Grouz et al., 2018; Billen et al., 2018a; Raimonet et al., 2015; Vilmin et al., 2015b).

The Riverstrahler model (Billen et al., 1994; Garnier et al., 2002; Ruelland et al., 2007; Thieu et al., 2009; Passy et al., 2013) was developed in the early 1990s to simulate and help design management measures against organic pollution by point sources, oxygen deficits downstream from Paris, and eutrophication of large upstream tributaries (Seine, Marne, Oise) that made drinking water production difficult. Riverstrahler represented the whole drainage network, from headwaters to the estuary, by a combination of major branches individually described at $1-\mathrm{km}$ resolution and subbasins. For the latter, the complex network of tributaries was represented by a regular confluence scheme of river orders with average morphological characteristics by stream order. Water flows in the hydrological network were calculated from specific discharges generated within the watershed of the different subbasins and branches considered, as calculated from recorded daily discharge at available gauging stations, and separated into surface runoff and base-flow components using a recursive filter (Eckhardt, 2008; Arnold and Allen, 1999). Simulations were provided at a 10-day resolution, considering permanent flow conditions at that time scale although 
TABLE 5.2.2 Average morphological characteristics of river reaches by stream order (Marescaux, 2018).

\begin{tabular}{lcllrlr}
\hline Stream order & Stream numbers & $\begin{array}{l}\text { Drainage area } \\
\mathbf{( k m}^{\mathbf{2}}\end{array}$ & $\begin{array}{l}\text { Cumulated length } \\
\mathbf{( k m )}\end{array}$ & $\begin{array}{l}\text { Width } \\
(\mathbf{m})\end{array}$ & $\begin{array}{l}\text { Depth } \\
\mathbf{( m )}\end{array}$ & $\begin{array}{l}\text { Slope } \\
(\mathbf{m} / \mathbf{m})\end{array}$ \\
\hline 1 & 2643 & 30,097 & 10,688 & 2.4 & 0.1 & 0.00952 \\
2 & 603 & 10,635 & 4488 & 5.1 & 0.3 & 0.00345 \\
3 & 148 & 7798 & 2936 & 8.3 & 0.4 & 0.00224 \\
4 & 47 & 6690 & 1,92 & 22.2 & 0.8 & 0.00177 \\
5 & 13 & 8627 & 1044 & 45.0 & 1.1 & 0.00103 \\
6 & 4 & 7864 & 636 & 77.7 & 2.5 & 0.001 \\
7 & 1 & 4573 & 467 & 186.2 & 2.6 & 0.00101 \\
\hline
\end{tabular}

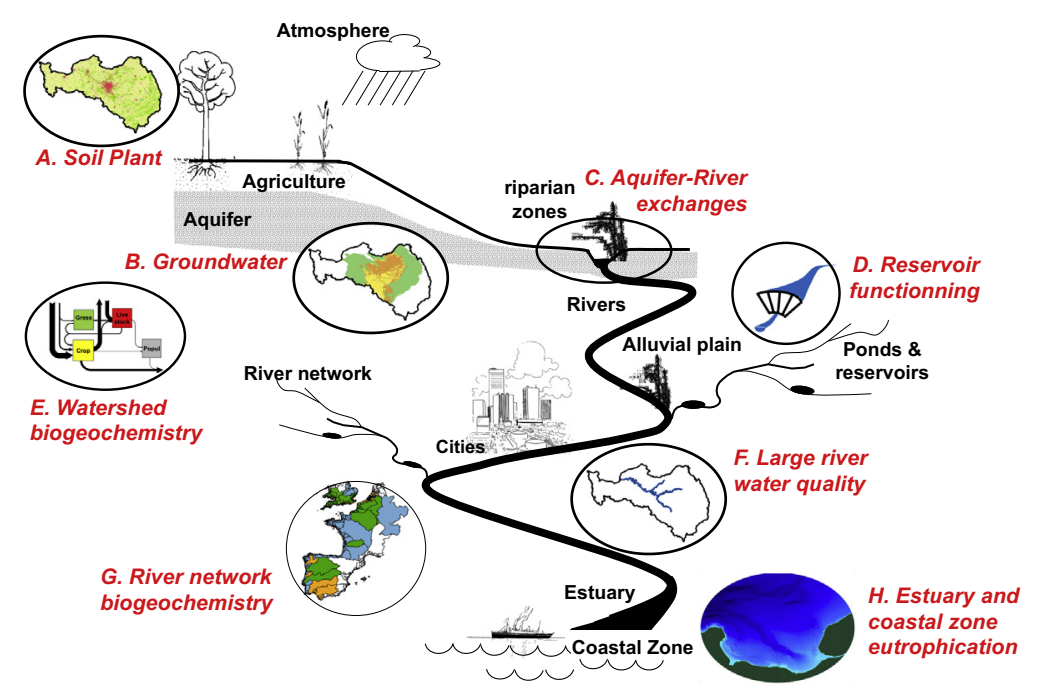

FIGURE 5.2.2 Representation of the modeling tools currently used for the Seine: a cascade of models. STICS (A), MODCOU (B)/CaWaQS (C) for groundwaters, GRAFS (D)-Riverstrahler (E), BarMan (F), ProSe (G). Note that collaborations with IFREMER chain the PIREN-Seine modeling approaches to the estuary and coastal zone (Eco-Mars-3D model $(\mathrm{H})$ ).

calculations of biogeochemical processes were carried out with a 10-min time step. RIVE also is included in a modeling approach describing the reservoirs (BarMan) (Fig. 5.2.2). The Riverstrahler model is currently applied to the Seine to help the Seine Water Agency to respond to the EU-WFD (Water Framework Directive, 2000).

The ProSe model (Even et al., 1998, 2007a,b,c; Flipo et al., 2004; Vilmin et al., 2015a) was designed to simulate major stretches of the Seine and its tributaries, particularly in the Paris region, on the basis of a specific detailed morphological description at 100-m resolution, and including highly transient events with time steps of a few minutes. The hydraulic behavior of each stretch was dynamically calculated by solving onedimensional Saint-Venant equations. The upstream boundary conditions to the ProSe model can be either direct observations or simulation by Riverstrahler (Even et al., 2007a,b,c). The complementarity of the two models allows covering the entire range of spatial and temporal scales, e.g., from eutrophication and organic pollution within the whole drainage network to highly transient situations, such as storm events generating the discharge of untreated wastewater effluents (Fig. 5.2.2).

These modeling approaches require quantification of human activities and, in particular, point and diffuse sources of nutrients into the river. Point sources consist of industrial and urban wastewaters released into surface waters directly after treatment by WWTPs. Approximately 2000 discharge points are GIS-located on the drainage network and documented in terms of emitted pollution. Diffuse sources of nutrients are characterized by the composition (using all variables in the RIVE model) of the two components of specific runoff generated by each land-use class in the basin. A biogeochemical accounting model of the agrofood system at the 
department scale (Département, level of administrative division of France, equivalent to the official division of the EU for regional statistics, NUTS3) has been developed (GRAFS approach, Billen et al., 2013; Le Noë et al., 2017) for estimating $\mathrm{N}$ and $\mathrm{P}$ concentrations and their relation with the structure of the agricultural system (Fig. 5.2.2).

\subsubsection{Groundwater modeling and its coupling with surface waters}

The mean water budget of the basin consists of rainfall, $760 \mathrm{~mm} / \mathrm{yr}$, of which $72.5 \%$ is lost by evapotranspiration, $12.5 \%$ comprises Hortonian and fast subsurface runoff, and $15 \%$ constitutes aquifer recharge of $120 \mathrm{~mm} / \mathrm{yr}$ in the basin. Groundwater resources in the Seine River basin are today of high strategic importance in terms of water resources because about $1 \times 10^{9} \mathrm{~m}^{3}$ per year of groundwater in the basin is extracted by pumping, corresponding to $12 \mathrm{~mm} / \mathrm{yr}$ and one-third of the total water withdrawals, the remaining being taken from surface water. To assess the state and trajectory of water resources, especially groundwaters, a distributed physically based model of the Seine basin is used (MODCOU, Gomez et al., 2003; Pryet et al., 2015). It combines surface and groundwater processes between seven aquifer units, from recent alluvial deposits to lower cretaceous formations. MODCOU is currently coupled with the agronomic model STICS to determine aquifer nitrate contamination (Fig. 5.2.2). It corresponds to three quarters of the impluvium of the whole aquifer system. Following recent developments in the conceptualization of stream-aquifer exchange (Flipo et al. 2014), the model also includes alluvial plains (Labarthe et al., 2015; Labarthe, 2016). The blueprint of MODCOU was initially published by Marsily et al. (1978) and implemented by Ledoux and colleagues (Ledoux, 1980; Ledoux et al., 1989). It then evolved into two daughter models, EauDyssee (Saleh et al., 2011; Flipo et al., 2012; Pryet et al., 2015; Baratelli et al., 2016) and CaWaQS (Catchment Water Quality Simulator), that presently focus on stream-aquifer interfaces (Flipo et al. 2005, 2007a; Labarthe, 2016) (see Fig. 5.2.2).

Stream-aquifer exchanges were estimated by the model along with the entire Seine River network at 1$\mathrm{km}$ resolution (Labarthe et al., 2015; Pryet et al., 2015; Flipo et al., 2016). On average, the river network drains $1 \mathrm{~L} / \mathrm{s} / \mathrm{km}^{2}$ from the aquifer system. Eighty-two percent of the river network is in a gaining configuration, which means that it drains the aquifer system. This proportion would rise to $97 \%$ if all water withdrawals in the aquifer system were stopped. In other words, anthropogenic pressure on the groundwater resources leads to a significant alteration of surface-subsurface functioning, which in turn modifies the biogeochemical functioning of the interface and greenhouse gas emissions (Newcomer et al., 2018). The consequences of such alterations on river ecology are still poorly understood and are the focus of ongoing research (Marmonier et al., 2012). Concerning the downstream part of the river network connected to alluvial plains (stream orders $>3$ ), pumping removes $10 \mathrm{~m}^{3} / \mathrm{s}$ from the hydrosystem. Half of it is taken up from alluvial aquifers and the other half is taken directly from rivers which, as a consequence of pumpings, infiltrates towards the underlying aquifer unit (Pryet et al., 2015). Most groundwater is pumped for drinking water production (74\%), for industrial purposes $(16 \%)$, and irrigation by the agricultural sector $(10 \%)$, which is low in the Seine basin.

The stream-aquifer interface, that is hyporheic zone, is a biogeochemically reactive ecotone, which filtrates waters flowing through it. In a biogeochemical perspective, it is important to quantify the total amount of exchanged water independently of the direction of flow. This flux is called "gross flux" in opposition to net flux discussed above. At the Seine basin scale, the gross flux is $50 \%$ greater than the net flux. During dry years, the above-mentioned estimates remain almost unchanged, but in contrast, gross and net exchange fluxes increase by $50 \%$ during wet years. A priori, we assume that a general elevation of river water levels due to flooding would increase the number of losing reaches and therefore the amount of infiltrating water. This is actually true during flood events when alluvial aquifers are recharged by rivers, but soon after flood events, aquifers contribute more than usual to river recharge by an increased upward movement. The combination of these two dynamics generates, annually, a significantly larger gross flux as well as a global upward and downward flux leading to high biogeochemical activity.

\subsubsection{Water chemistry and chemical contamination}

Today, river quality of the Seine basin is monitored at more than 800 regulatory stations by the basin authority (AESN), local public authorities, the sewage management institution for Paris conurbation (SIAAP, Syndicat interdépartemental de l'agglomération Parisienne), and drinking water industries. The enormous amount of resulting data is used to assess river quality according to the EU-WFD (2000), with some limitations in information on the (1) reference status of the basin (before human pressures), (2) present biogeochemical functioning of the river system, and (3) complex interactions between the basin, river, and society over decades and longer. To fill these gaps, the PIREN-Seine interdisciplinary scientific program conducted longterm studies at selected sites over the whole basin 
such as rural catchments (e.g., Orgeval), suburban catchments (e.g., Orge), Bassée alluvial wetland, urbanized basins, and most impacted river sections (downstream of the main Paris WWTP, Seine-Aval, and pollutant sources from sewers, hospitals and animal husbandry). Other strategies concerned the distribution of biogeochemical indicators by stream order, the longitudinal upstream-downstream profiles from the upper Seine to the estuary, the export of all substances at the basin outlet (Poses), and coring of alluvial deposits (Bouafles) (see locations on Fig. 5.2.1). All these data have contributed to understanding and modeling the Seine basin.

\subsubsection{Maximum pollution stage established on natural backgrounds of ions and heavy metals}

Comparison of current concentrations of ions $(\mathrm{mg} / \mathrm{L})$ in river waters and contamination of particulate matter with heavy metals $(\mu \mathrm{g} / \mathrm{kg}$; deposited sediments, suspended particulate matter [SPM]) with those of preanthropogenic conditions, used as a reference, is one way to assess river alteration. In Western Europe, such assessment is difficult because basins have been under human influence for centuries, well before the first analyses. References may be reconstituted based on historical records, analyses on small pristine streams (e.g., forested areas), and from archeological deposits. Analysis of total dissolved salts (TDS) in the Seine River in
1848 in Paris was one of the first measurements ever done. This analysis is very close to the estimated theoretical composition of the river at its outlet, based on monolithologic forested streams and weighted by the lithological composition of the basin. These two analyses are combined here to provide a reference level for major ions (Table 5.2.3, A), which reflects the dominance of carbonate rocks in the basin, with gypsum-derived sulfate and atmospheric sea-salt input of $\mathrm{NaCl}$. From 1970 to 1990 (Table 5.2.3, B), this composition was heavily modified. TDS increased by $60 \%$, but individual ions increased much more $\left(3.5 \times\right.$ for $\mathrm{SO}_{4}{ }^{2-}, 4 \times$ for $\mathrm{K}^{+}, 5 \times$ for $\mathrm{Cl}^{-}$, and $7 \times$ for $\mathrm{Na}^{+}$). These levels resulted from industrial and urban uses, potassium originated from agriculture as well as a part of sulfate. Rock weathering may have been enhanced by the use of sulfatecontaining fertilizers, therefore increasing concentrations of other ions.

Chemical values of Paris' main sewers from 1980 to 1990 (Table 5.2.3, C) showed many similarities with those of the river at that time (Meybeck et al., 1998). The per capita loads of salts $(\mathrm{kg} / \mathrm{cap} / \mathrm{yr})$ are calculated from the extra load of salts carried by the Seine to the ocean, divided by the basin population (Table 5.2.3, D). They are in the same order of magnitude as those found for other European and North American rivers at the same time, and the ranking of ions is similar (Meybeck et al., 1998). Dissolved salts, which are easy to measure, were one key criterion of the first water quality scale in 1971, which was used for 20 years (Bouleau et al., 2017).

TABLE 5.2.3 Background and reference levels of major ions and heavy metals of the Seine River, with maximum pollution levels and urban pressures (see text).

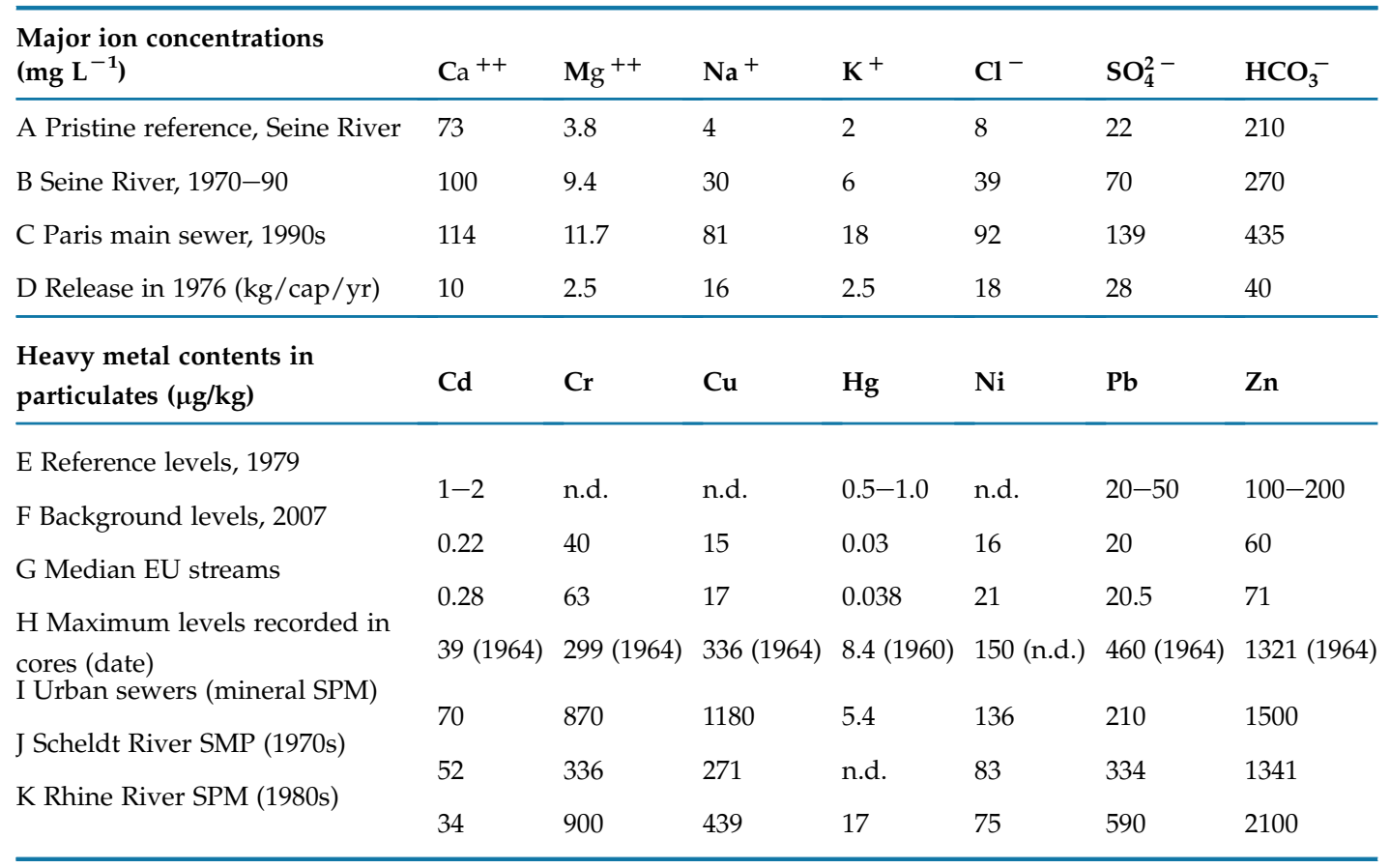

n.d., no data. 
Seine water was considered to be appropriate for all uses with these criteria, and the human impact on major ions was not addressed.

The first determination of a natural reference for toxic metals by the basin authority (AESN, Table 5.2.3, E) was erroneous. New estimates are based on minimum levels recorded in preliminary analyses of SPM and archeological deposits in Paris (dated 5500 BP). Another set of natural backgrounds was established (Meybeck et al., 2007; Table 5.2.3., F) with much lower figures for the most toxic and ubiquitous metals in that period: cadmium $(\mathrm{Cd})$ and mercury $(\mathrm{Hg})$. These backgrounds are similar to the median contents of EU streams, established by Salminen et al. (2005) (Table 5.2.3, G; in Meybeck, 2013).

The Seine River was extremely polluted by heavy metals 60 years ago (Section 5.2.5.4), with maximum contents in fine sediments deposited at the outlet at Poses (Fig. 5.2.1) in the early 1960s (Table 5.2.3, H; Meybeck et al., 2007; Le Cloarec et al., 2011; Ayrault et al., 2010, 2012, 2013). The maximum recorded during the PIREN-Seine studies at specific sites near Paris' main combined sewer overflows reached $130 \mu \mathrm{g} / \mathrm{kg}$ for $\mathrm{Cd}$ and $26 \mu \mathrm{g} / \mathrm{kg}$ for $\mathrm{Hg}$; i.e., $500 \times(\mathrm{Cd})$ and $1000 \times(\mathrm{Hg})$ the background values. These levels of contamination are similar to the average composition of urban sewers in the industrial world around the 1970s (Meybeck, 2013; Table 5.2.3, I). Extreme contamination of the Seine at that time is by no means exceptional; average contents found in the Scheldt SPM (Zwolsman and Van Eyck, 1999) and in the Rhine SPM (Malle, 1990) were quite similar (Table 5.2.3, J and K). The problem of heavy metals contamination of Western European rivers was raised for the first time by Müller and Förstner (1973). After this alert, it took 10 years to start monitoring Seine river sediments on the fraction $<2 \mathrm{~mm}$. Due to the coarse nature of these sediments, the actual level of contamination of the Seine River was severely underestimated and never officially declared until sediment archives were analyzed (see Section 5.2.5.4).

\subsubsection{Urban pollution: water quality variables and modeling in the lower Seine}

Today, wastewater produced by the Parisian conurbation amounts to $2.7 \mathrm{Mm}^{3}$ per day of which $2.5 \mathrm{Mm}^{3}$ is treated daily by the SIAAP and the rest by other municipalities. The Seine-Aval WWTP (Photo 5.2.1) is the largest facility in Europe with $1.5 \mathrm{Mm}^{3}$ treated every day, and the wastewater load is now shared with 10 additional WWTPs with individual treatment capacities greater than $30,000 \mathrm{~m}^{3}$ /day (from 2000 to 2015, treatment efficiency increased from $70 \%$ to $>95 \%$ for biological oxygen demand after 5 days (BOD5), from $30 \%$ to $90 \%$ for reduced nitrogen, and from $40 \%$ to $80 \%$ for phosphorus (Rocher and Azimi, 2017).

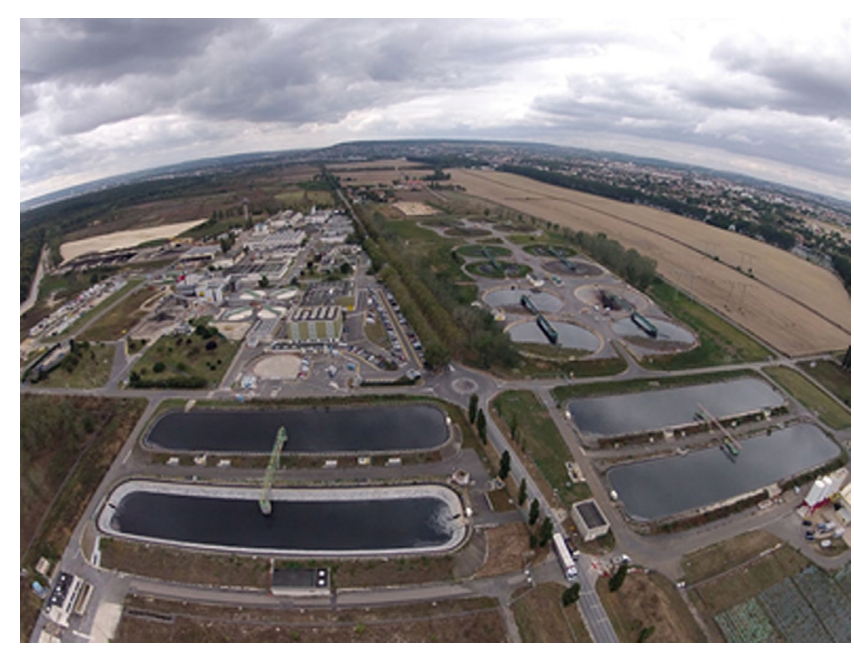

PHOTO 5.2.1 TheSeine-Aval wastewater treatment plant, the largest in Europe. Taken in September 2012. https://fr.wikipedia.org/wiki/ Station_d\%27\%C3\%A9puration_Seine_Aval. Accessed 25_02_2019.

The impacts of these changes over the last few decades have been simulated by the Riverstrahler and ProSe models, the latter specifically dedicated to simulating water quality of the Seine River within Paris and lower Seine on a 10-min basis (Even et al., 2004, 2007a,b; Vilmin et al., 2016). The ProSe model output closely fits the observed continuous DO for the lower Seine in the west Paris conurbation (Fig. 5.2.3). It also shows multiscale temporal variability via (1) the gradual decline of DO during summer due to the decrease in receiving river discharge, (2) clearly marked diurnal variations linked to autotrophy/heterotrophy cycles, and (3) lowered DO episodes, below $4 \mathrm{mg} / \mathrm{L}$, mainly resulting from combined sewer overflow (CSO) during intense summer rainfall events. The difference between simulated DO minima and observed minima is not completely understood and likely related to newly installed air injectors triggered during overflow events (see Section 5.2.8.3).

The ProSe model has been used by Paris sewer managers (Syndicat Interdepartemental de l'Assainissement de l'Agglomération Parisienne, SIAAP) to simulate and optimize the impacts of new WWTPs. Maintaining low nitrite concentrations in aquatic systems is currently a major issue for Seine basin managers, which has been addressed by the model. Among other water quality variables, ProSe accurately represents nitrite over a 250-km lower river reach, from Paris to the Seine outlet at Poses. The quantiles of water quality observed are accurately simulated and show that water quality downstream of the Seine-Aval WWTP (at km 65) is good 10\% of the time, acceptable $50 \%$ of the time, and poor $10 \%$ of the time (Raimonet et al., 2015). The increase in treatment capacity in WWTPs and sewer network interconnections made it possible to reduce the volume of 


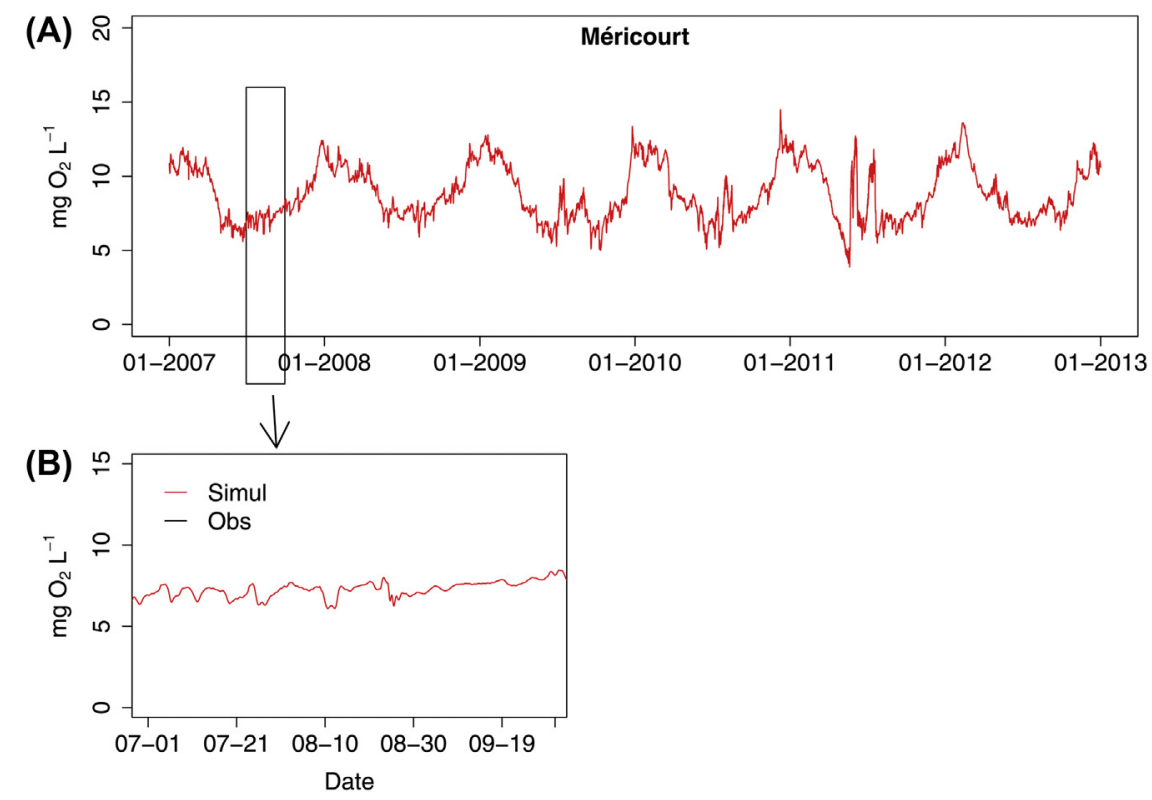

FIGURE 5.2.3 Dissolved oxygen DO, in $\mathrm{mgO}_{2} / \mathrm{L}$, simulated by ProSe, at Méricourt, downstream of all urban discharges from the Parisian conurbation. (A) For 2007-12. (B) For 3 months in 2007 (1 July-30 September). Observations are shown for comparison (Vilmin et al., $2015 a$ ).

combined sewer overflows by $90 \%$ (see also see Section 5.2.8.3). Massive fish kills that occurred at these stations in the Seine since the 1870s (Dmitrieva et al., 2018) have been considerably reduced in the last 20 years. As a consequence of water quality improvement, the fish assemblage has improved (Section 5.2.8.6).

\subsubsection{Regulated organic pollutants: river water, particles, and fish contamination}

Although regulatory water quality monitoring started in 1971, persistent organic pollutants have only been studied by scientists since 1985 and efficiently monitored after 2006. Historically, polychlorinated biphenyls (PCBs) and polycyclic aromatic hydrocarbons (PAHs) were the first pollutants studied in the Seine basin (Chevreuil et al., 1987, 1998; Blanchard et al., 1999; Teil et al., 2012). After PAHs and PCBs, other emerging organic pollutants were addressed by the PIREN-Seine program in the Seine River, including phthalates in plastizicers (Teil et al., 2012; Tran et al., 2015), alkylphenols (APs) such as alkylphenol polyethoxylates and bisphenol A (Cladière et al., 2010, 2013, 2014), pharmaceuticals (Tamtam et al., 2008), polybromodiphenyl ethers (PBDE) such as flame-retardant (Tlili et al., 2012), perfluorinated compounds (Labadie and Chevreuil, 2011a, b), and more recently microplastics (Dris et al., 2015, 2018). Most of these studies aim mainly at quantifying levels in the river corridor, assessing the sources and dynamics of these pollutants under different hydrological conditions (seasonal variability, low-flow periods vs. floods) and at key stations selected for different types of human pressures (e.g., upstream/downstream of Paris, rural stations, treated and untreated sewage).

Even in a low turbidity river as the Seine River (mean $\mathrm{TSS}=20 \mathrm{mg} / \mathrm{L}$ ), PAHs and PCBs are mainly associated with suspended solids. For PAHs, particulate fractions account for $35 \%-80 \%$ of the total load, depending on the molecular weight of PAH. For PCBs, a similar trend is observed depending on their chlorination amount. Both families are highly correlated to suspended solids (TSS) and river flow (Q), resulting in concentration variations over one order of magnitude for PAHs and diethylhexyl phthalate (DEHP) over 1 year of high-frequency monitoring of the Seine at Paris (Fig. 5.2.4). In Paris, about $60 \%$ of the annual pollutant fluxes can transit during a single flood, simultaneously with a peak of suspended solids, as in February 2004. PAH fluxes in Paris vary between 400 and $800 \mathrm{~kg} / \mathrm{yr}$ for $\sum 14$ PAHs and are about $100 \mathrm{~kg} / \mathrm{yr}$ for $\sum 7$ PCBs. The current PAHs and PCBs contents in suspended solids in the lower Seine, downstream of Paris, is in the order of $5-10$ and $0.1-0.3 \mu \mathrm{g} / \mathrm{g}$, respectively. These levels are one order of magnitude less than those measured 25 years ago.

The presence and fate of dissolved phthalates have been studied in the Seine at Paris. At all sites, DEHP was the most abundant compound (96-1200 ng/L), followed by di- $n$-butyl phthalate (DnBP) (51-640 ng/L), a ranking that matches past proportions of European phthalate production. Concentrations of phthalates vary over the year in relation to precipitation, with concentration peaks preceding flow rate peaks. This suggests local point sources such as urban inputs, 

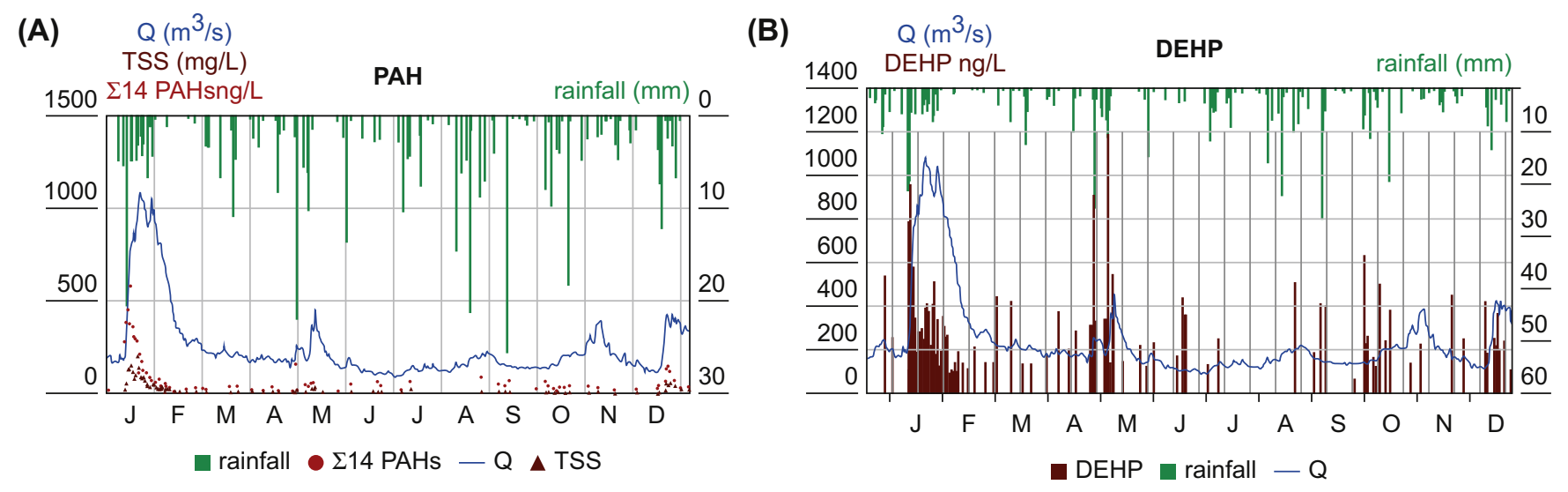

FIGURE 5.2.4 High-frequency monitoring of total polycyclic aromatic hydrocarbons (PAHs) and diethylhexyl phthalate (DEHP) in the Seine River at Paris in relation to local water flow (Q), suspended solids (TSS) and local rainfall (January-December 2004).

stormwater runoff, or resuspension of contaminated sediments, but their relative contribution is actually unknown. First assessments of DEHP exported by the Seine vary between 800 and $2200 \mathrm{~kg} / \mathrm{yr}$.

PAHs and PCBs accumulation in roach (Rutilus rutilus) was studied (Chevreuil et al., 2009) at different stations (see Fig. 5.2.1); that is, a reference site with minimal pressures (Marnay, a river station in Bassée). a station downstream of Paris (Epinay) and a station close to the estuary (Poses). Water and sediments were also examined (Fig. 5.2.5A, B). For PCBs, a significant correlation was found between sediment contamination and roach accumulation (Fig. 5.2.5A). Bioaccumulation of PCBs in fish tissue was observed for all stations. Contrary to PCBs, PAHs content in roach was more than 100 times lower than those found in the sediment, since PAHs are metabolized by fish and thus not bioaccumulated (Fig. 5.2.5B).
More recently, PBDEs, PCBs, and phthalates were examined in three fish species (roach, chub and perch) from the urban Orge River (see Fig. 5.2.1), which flows in a densely populated area of Ile-de-France (Teil et al., 2012). Muscle contents in increasing order ranged as follows: $12-18 \mathrm{ng} / \mathrm{g}_{\mathrm{dw}}$ for PBDEs ( tri-hepta), $120-170 \mathrm{ng} / \mathrm{g}_{\mathrm{dw}}$ for PCBs $(\Sigma 7)$ and $2250-5125 \mathrm{ng} / \mathrm{g}_{\mathrm{dw}}$ for phthalates $(\Sigma 7)$. No variation was observed between contaminant content and lipid levels, and no biomagnification was found according to the trophic level for PBDEs and PCBs, whereas for phthalates the highest contents were found in perch. Bioaccumulation factors for PCBs in perch and roach muscle were correlated with the chlorination amount. In roach, the correlation slope showed a decreasing order of importance: gonad $>$ liver $>$ muscle. The biota/sediment accumulation factors varied from 0.1 to 29.2 , from 1.6 to 4.8 , and from 1 to 123.5 for PBDEs, PCBs, and phthalates,
(A)

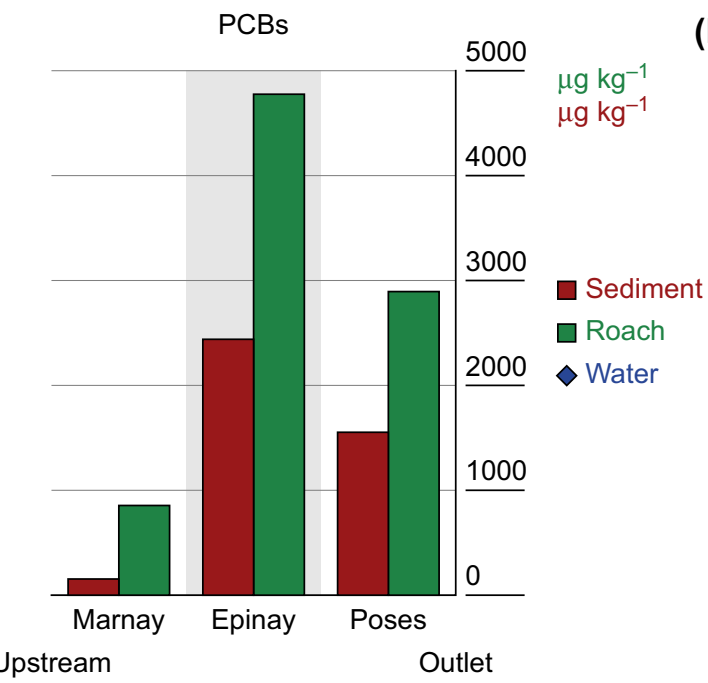

(B)

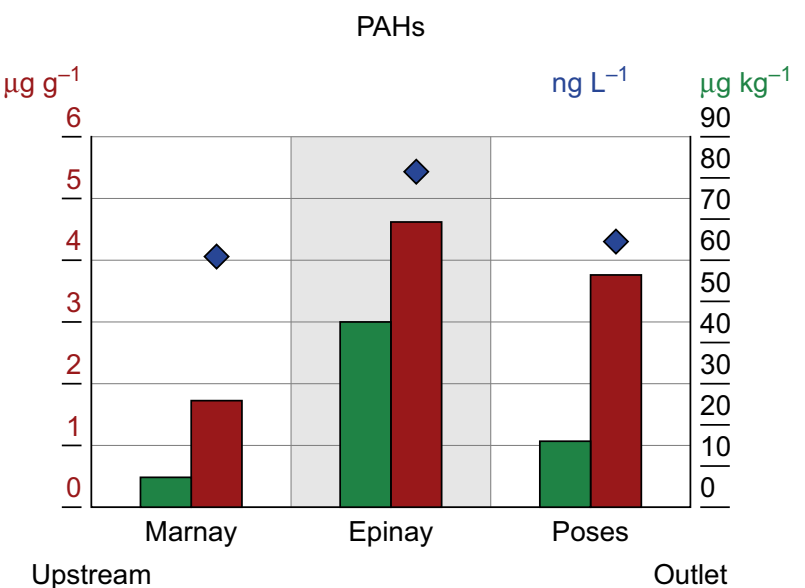

FIGURE 5.2.5 Patterns of water and sediment contamination by PCBs and PAHs. (A) PCBs: contents in roach and sediment; (B) PAHs: contents in roach, sediment and water. Upstream of Paris (Marnay), within Paris suburbs (Epinay), and at the basin outlet (Poses). Sediment and roach contents in $\mu \mathrm{g} / \mathrm{g}_{\mathrm{dw}}$ and $\mu \mathrm{g} / \mathrm{kg}$, respectively, and in $\mathrm{ng} / \mathrm{L}$ for water concentrations. 
respectively. These results confirm the marked and multiple sources of contamination of the Seine downstream of Paris from urban and industrial sources. Further, the specific patterns of each contaminant family, sometimes even each individual compound, are also shown with heterogeneity also observed for pesticides (see Section 5.2.5.6).

\subsubsection{Sediment archives}

The use of sediment archives allows the long-term assessment of contamination, decades before the first direct measurements on the river and biota. Sediment archives were obtained from deposited sediments cored in lakes and reservoirs, the river's floodplain (Photo 5.2.2), estuarine wetlands, and harbors. They allow the reconstruction of long-term contamination-over decades to centuries - of particulate material, particularly before reliable monitoring of many micropollutants was established. Cores taken for the first time after 2005 in the Seine basin allowed the reconstruction of heavy metals, PCBs, PAHs, alkyl phenol contents over 50-90 years, unveiling the former extreme contamination of the lower Seine and some tributaries. When compared to the history of pressures (urban, industries) and responses (regulations, WWT) at sites where cores

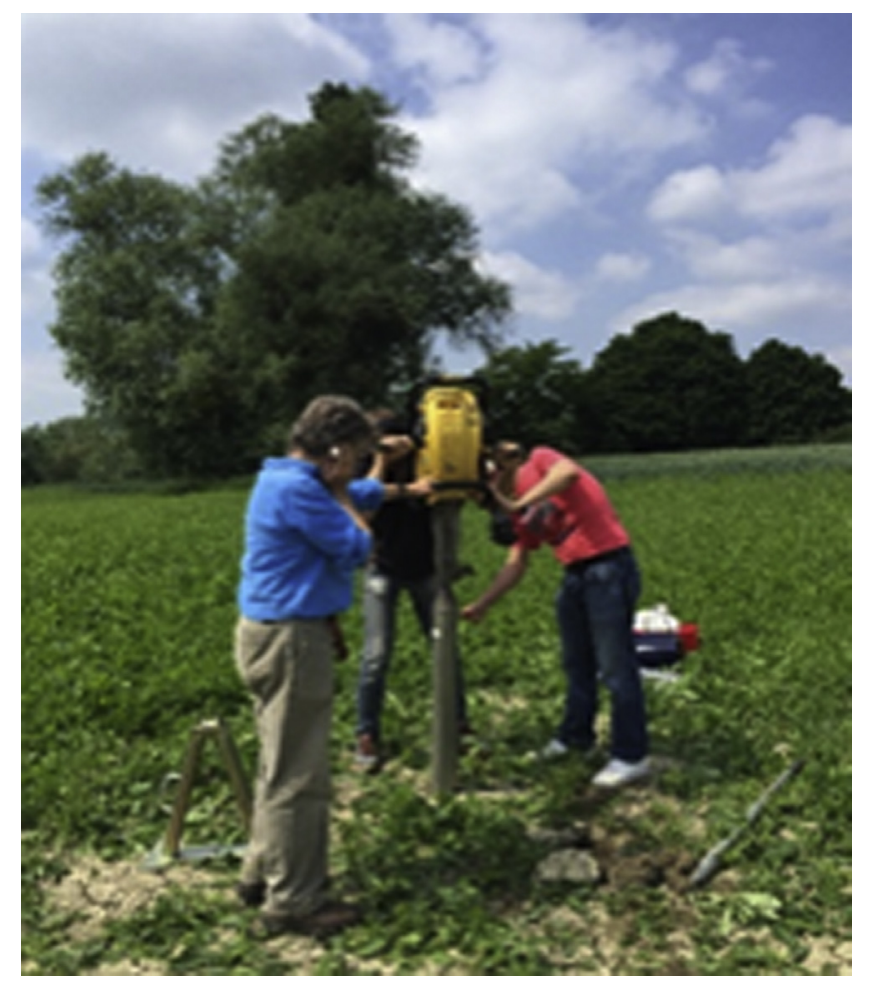

PHOTO 5.2.2 Floodplain sediment sampling by portable corer at Bouafles on May 23, 2018 (see location on Fig. 5.2.1). The Seine River channel is at $30-40 \mathrm{~m}$. Credit: Sophie Ayrault. are taken, these contamination trends define the trajectories within subbasins (Meybeck et al., 2018). Since the spatial distribution of pressure is not homogenous, four coring sites were selected to represent a general gradient through the Seine River basin: the near pristine upper Yonne headwaters in Morvan (Pannecières reservoir), the upper Seine at Troyes dominated by agriculture, the lower Oise River dominated by industrial activity (mainly past) and the Seine basin outlet (Bouafles and Muids) that accumulates all pressures, urban (Paris WWTPs as the Seine-Aval mega facility, see Fig. 5.2.1), and industrial and intensive agriculture (Beauce region). All cores analyzed exhibit a clear chronology based on the measurement of radioactive tracers, ${ }^{137} \mathrm{Cs}$ and ${ }^{210} \mathrm{~Pb}$ (Bonté et al., 2000).

\subsection{Inorganic pollutants}

Concentration profiles of $>30$ elements such as As, $\mathrm{Ag}, \mathrm{Cd}, \mathrm{Cu}, \mathrm{Hg}, \mathrm{Pb}, \mathrm{Sb}$, and $\mathrm{Zn}$ were determined. The period spans 1915-2004 and 1935-2004, depending on the core. Profiles are compared to background levels of metals and arsenic (As), established on prehistoric sediments from archeological samples (5000 years BP), and confirmed by measurements on pristine headwaters (Meybeck et al., 2007) (see Table 5.2.3). The main features are (1) a significant contamination level already in 1915 for all metals and As, (2) a maximum of contamination in the 1950s (see Table 5.2.3), and (3) a beginning of decontamination in the 1960s with a maximum decontamination rate between the 1970s and 1990s (Le Cloarec et al., 2011; Ayrault et al., 2010). Isotopic investigations revealed a diversity of lead $(\mathrm{Pb})$ sources: contamination due to lead additives in gasoline was only a page in the long book of the relationship between humans and lead (Ayrault et al., 2014). The Pb profile in different cores highlights the resilience potential of the river facing a huge industrial, point source, contamination. Downstream from an industrial site, where a $\mathrm{Pb}$ concentration up to $400 \mathrm{mg} / \mathrm{kg}$ was observed in the $1960 \mathrm{~s}, \mathrm{~Pb}$ contents decreased by one order of magnitude within 60 years, resulting from changes in industrial activities due to environmental regulations restricting the release of industrial contaminants to the river (Lestel et al., 2007; Lestel, 2012; Meybeck et al., 2007). When compared to other rivers in Europe, the Lambro (Milan), Spree (Berlin), a major tributary of the Havel River, and Senne (Brussels) (Fig. 5.2.6), contamination archived in cores shows that these rivers, all characterized by extreme pressures/river dilution power ratios, have had extreme metal contamination (Meybeck et al., 2017). Each river/ city cluster and each metal have its own trajectory: in the Havel (Spree)/Berlin, contamination decrease was observed after 1989, some 50 years (lead) to 30 years (cadmium) later than for the Seine, due to local pressure history. 

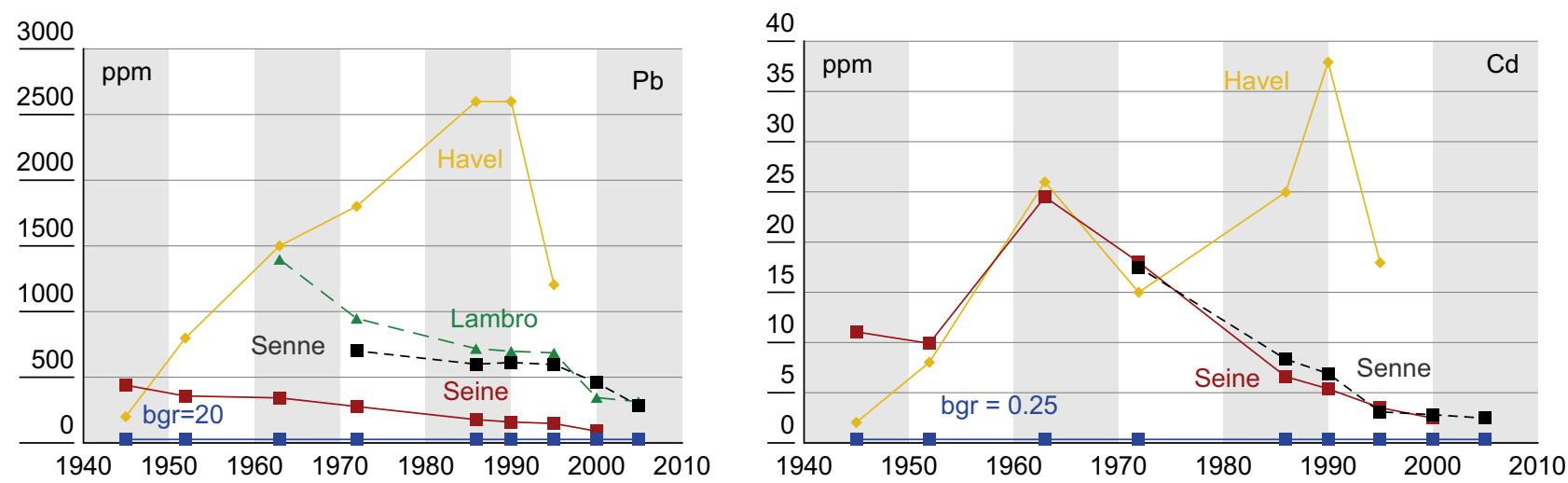

FIGURE 5.2.6 Trends of metal contents of sediments expressed in $\mu \mathrm{g} / \mathrm{g}$ in four rivers/cities for Pb and Cd (Meybeck et al., 2017). Background (bgr) levels are similar for all rivers, $20-30 \mu \mathrm{g} / \mathrm{g}$ for $\mathrm{Pb}$ and $0.2-0.3 \mu \mathrm{g} / \mathrm{g}$ for $\mathrm{Cd}$.

The in-depth study of metal flows within the basin (Thévenot et al., 2007; Lestel et al., 2007; Lestel, 2012) shows that from $1 \%$ to $10 \%$ of the total amount of metal imports were leaking into the river system at the peak contamination period. These leakage rates, a major environmental efficiency indicator (Meybeck, 2013), today have been reduced tenfold (Meybeck et al., 2007), while the consumption of most metals increased, except mercury (Le Cloarec et al., 2011), regulated in the late 1970s, and cadmium regulated in 1985 by the EU. Hotspots of river sediment and soil contamination can still be found within the basin; this heritage remains a challenge for the future and explains why suspended sediment is still contaminated for most elements, compared to preanthropic levels, as frequently observed in other river basins in the Anthropocene (Rockström et al., 2014; Meybeck and Lestel, 2017).

\subsection{Particulate organic pollutants}

The Seine outlet core (Bouafles) provides detailed trends, close to the annual resolution of contamination for 1945-2005 period for four particulate organic pollutants (POP) families (13 PAHs, 15 PCBs, 3 APs, and 8 PBDEs) (Fig. 5.2.7) and makes it possible to establish the releases and historical trends of these organic micropollutants in a long-term heavily urbanized and industrialized river basin (Lorgeoux et al., 2016). They exhibit different sources, uses, and histories, that is, specific trajectories.

The PAHs profile reflects an old contamination associated with the use of coal for domestic heating, industries and power plants in the Seine basin (there has never been coal mining in this basin). Particularly, the postwar reconstruction period, 1952-60, is clearly marked with the highest levels, up to $90 \mathrm{mg} / \mathrm{kg}$ for

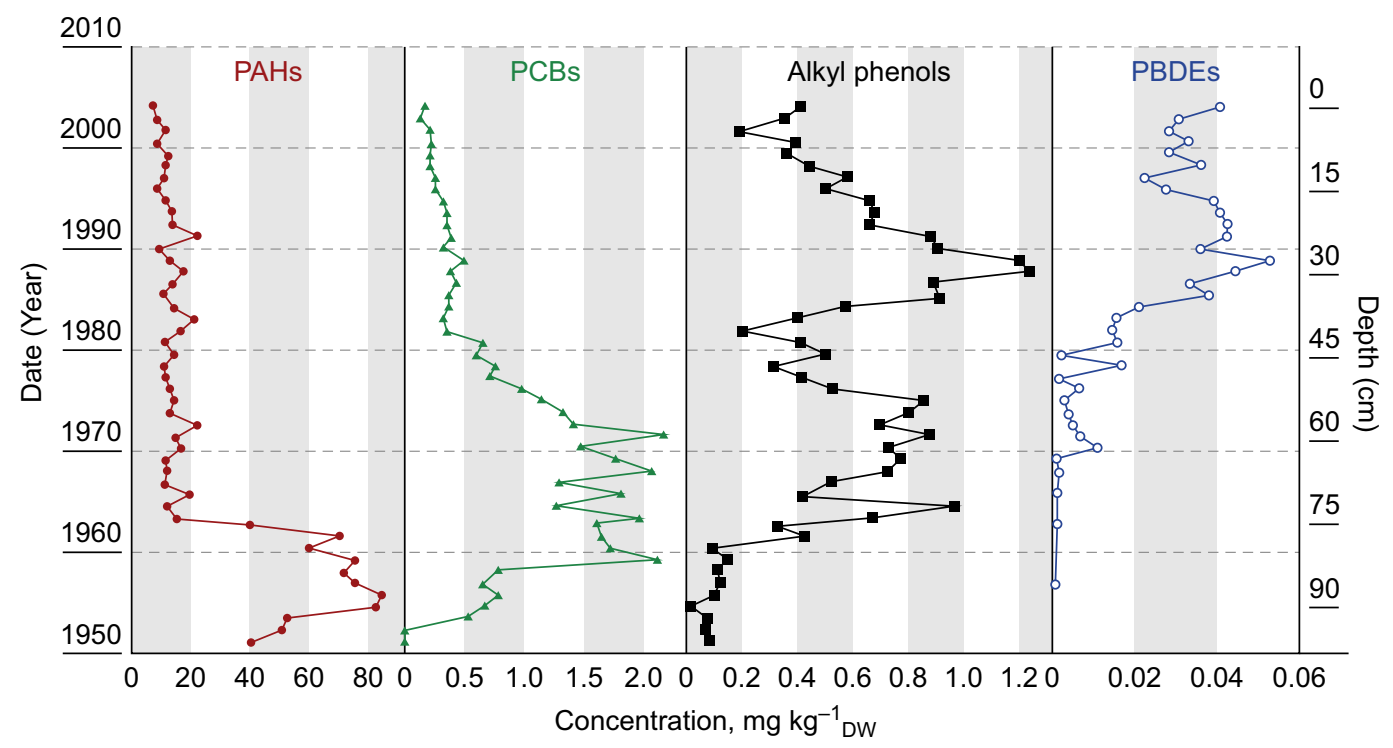

FIGURE 5.2.7 Sediment archives of past Seine River contamination. Profiles of contents (sum of compound concentrations in $\mathrm{mg} / \mathrm{kg}_{\mathrm{dw}}$ ) for PAHs, PCBs, APs, and PBDEs in floodplain sediment cores taken at the basin outlet. Adapted from Lorgeoux et al. (2016). 
¿PAHs. A pronounced decrease of PAHs was observed between 1962 and 1965, by a factor of 10, and today levels are stable at a level near $10 \mathrm{mg} / \mathrm{kg}_{\mathrm{dw}}$. This rapid decrease of PAHs in flood sediments after 1960 cannot be explained solely by changes in coal consumption for domestic heating, but also reflects a major industrial transformation with the closure of several gas plants based on the distillation of coal and reduction of coal in the steel industry. After 1968, coal was gradually replaced by heating oil in power plants, and contaminated sewage SPM was reduced by urban water management at the basin scale. Natural levels of PAHs-originating from fires-were not established but should be a few $\mathrm{mg} / \mathrm{kg}$ in sediments.

Contamination profiles of PCBs, PBDEs, and APs are different, reflecting a pattern of use and regulations specific to each family of products (Fig. 5.2.7). Starting points of contamination correspond to dates of initial industrial use: 1950s for PCBs, 1960s for APs, and 1970s for PBDEs. PCBs and PBDEs present a sharp increase, while APs increased more gradually. Before 1952, no PCBs were detected in cores, while PBDEs were not detected before 1965, as expected for such xenobiotic compounds. Contamination peaks occurred between 1960 and 1972 for PCBs, between 1965 and 1975, and between 1985 and 1995 for APs, and after 1990 for PBDEs. Finally, each peak was followed by a period of sharp decrease, depending on the regulations and availability of substitution products. For example, a rapid decline of PCBs from 1972 to the 1980s was observed followed by a slower reduction. These decreases are linked to the international ban of PCBs in open systems in 1972, then to the establishment of European regulations in 1987, which severely limited their use. For APs, a rapid decrease was observed since 1992 following the restriction of the use of alkylphenols imposed by the Oslo-Paris (OSPAR) convention on pollutant inputs into the Atlantic Ocean and to their substitution in detergents by other compounds. PBDE contamination shows a plateau pattern from 1995 to 2005.

None of these long-term trajectories was available before for the Seine-or any other French river-since these POPs have only been monitored very recently (2006) and/or monitoring has been inefficient due to a lack of appropriate analyzed media and analytical difficulties. These studies demonstrated the power and accuracy of sedimentary archives in floodplains, which give a comprehensive overview of the contamination in the Seine River basin. They are in agreement with previous studies dedicated to other European Rivers and highlights for the first time the specificities of this Seine basin. Sediment archives are still present in all European rivers, waiting to be analyzed to unveil their contamination history.

\subsubsection{Emerging pollution}

\subsection{Alkylphenol polyethoxylates and bisphenol A: differences in their origins}

Cladière et al. (2013) evaluated the concentration of bisphenol A (BPA) and alkylphenol polyethoxylates in river water along an urbanization gradient from upstream to downstream of Paris (Fig. 5.2.8). A significant influence of the megacity was shown for nonylphenoxy acetic acid $\left(\mathrm{NP}_{1} \mathrm{EC}\right)$ and BPA concentrations (respectively from 17 to $124 \mathrm{ng} / \mathrm{L}$ and from 20 to $66 \mathrm{ng} / \mathrm{L}$ ). For all other alkylphenol polyethoxylates $\left(\mathrm{NP}, \mathrm{NP}_{1} \mathrm{EO}\right.$, $\mathrm{NP}_{2} \mathrm{EO}$ ), no significant upstream-downstream pattern was noted, suggesting that urban sources of Paris have no major effect on receiving water, underlining the existence of diffuse sources in the Seine River basin (Fig. 5.2.8). In addition, the decrease of dissolved concentrations with the Seine at Marnay (upstream of Paris) and at Meulan (downstream) suggests the importance of point urban sources for $\mathrm{NP}_{1} \mathrm{EC}$ and reinforces the hypothesis of widespread dissemination of 4-NP at the scale of the basin.

\subsection{Pharmaceuticals: variable persistence in the river}

Tamtam et al. (2008) investigated the occurrence and fate of 17 antibiotics including quinolones, sulfonamides, nitroimidazoles, and diaminopyrimidines in the Seine under different hydrological conditions. Sulfamethoxazole was detected in every sample and showed the highest concentrations. Norfloxacin and flumequine were found to be the most ubiquitous quinolones, with $33 \%$ and $75 \%$ detection frequencies, respectively, at the most contaminated site (basin outlet, Poses). A longitudinal profile along the Seine River between Paris and the outlet at Poses and on two main tributaries, Marne and Oise, was also performed (Tamtam et al., 2008), suggesting large inputs of norfloxacin, ofloxacin, trimethoprim and sulfamethoxazole from WWTPs. The compounds detected showed different dissipation patterns along the river and behaviors under different hydrological conditions. Higher inputs of norfloxacin were found under low-flow conditions, which were rapidly attenuated along the stream. In contrast, sulfamethoxazole inputs increased under high-flow conditions, and dissipation of this compound was found to be slow. Similar behavior was observed for the synergist trimethoprim. Flumequine was also frequently detected and its input increased during flood events (Tamtam et al., 2008).

\subsection{Perfluorinated alkylated substances: $a$ point source origin}

Labadie and Chevreuil (2011a, b) studied the biogeochemical dynamics of 15 perfluorinated compounds 

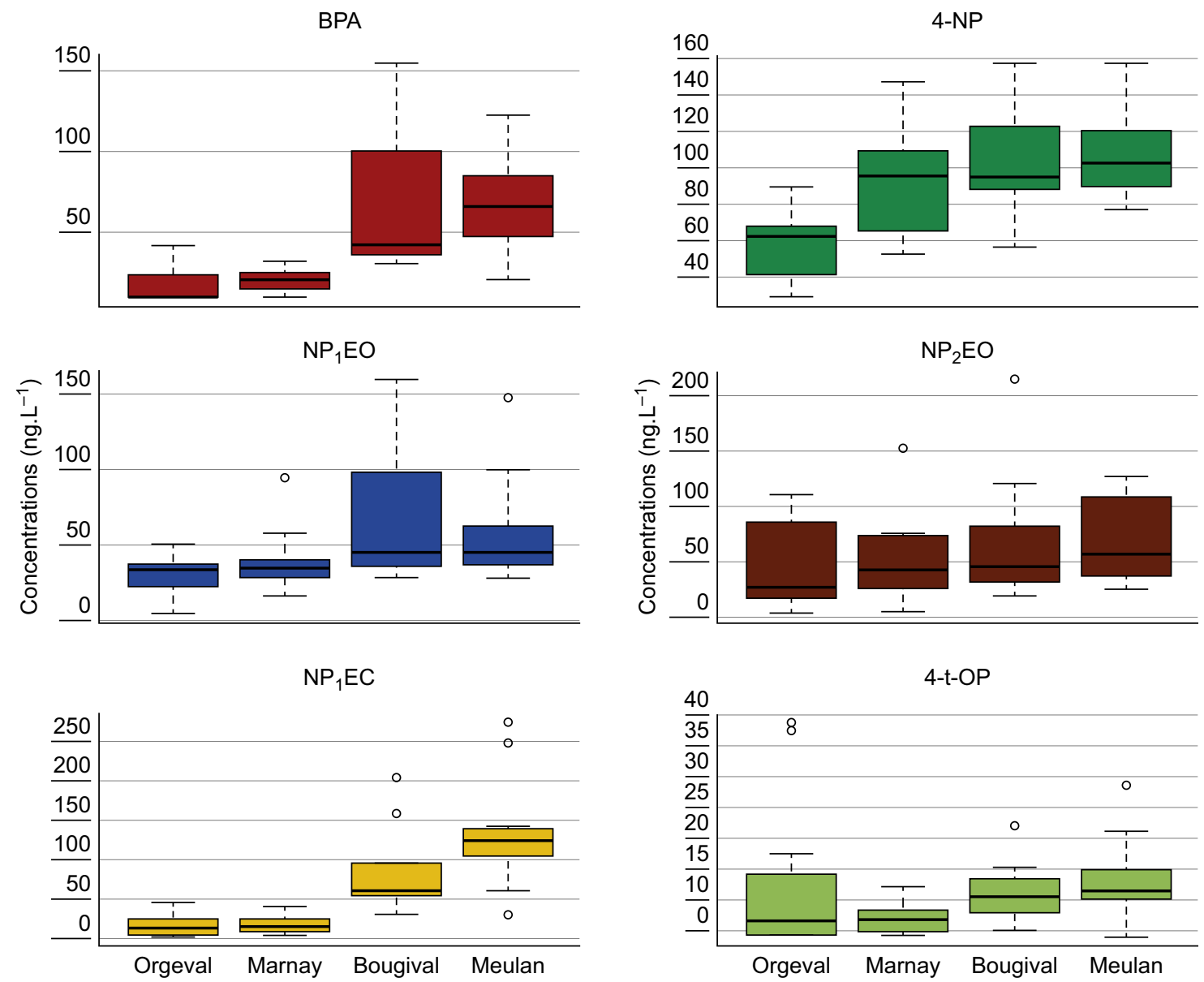

FIGURE 5.2.8 Levels of six emerging pollutants (see text) in an agricultural stream (Orgeval), in the Seine River upstream (Marnay), within (Bougival) and downstream of Paris Megacity (Meulan). Concentrations in ng/L. BPA, bisphenol A; 4-NP, 4-nonylphenol; $N P_{1} E O$, nonylphenol monoethoxylate; $\mathrm{NP}_{2} \mathrm{EO}$, nonylphenol diethoxylate; $N P_{1} E C$, nonylphenol ethoxyacetic acid; 4-t-OP, 4-tert-octylphenol.

(PFCs) in the Seine. Targeted compounds included $\mathrm{C}_{4}-\mathrm{C}_{10}$ sulfonates and $\mathrm{C}_{5}-\mathrm{C}_{14}$ acids. Eleven PFCs were detected, and $\sum$ PFCs ranged from 31 to $91 \mathrm{ng} / \mathrm{L}$ (median: $47 \mathrm{ng} / \mathrm{L}$ ). The molecular pattern was dominated by perfluoroalkyl sulfonates PFHxS and PFOS ( $>54 \%$ of $\sum$ PFCs), which were the only PFCs quantified in both dissolved and particulate phases. For these PFCs, the sorbed fraction was positively correlated with suspended sediment levels. Total PFC levels negatively correlated with river flow (Fig. 5.2.9). This suggests the predominance of point sources (likely WWTP effluent discharge), but a contribution of nonpoint sources such as combined sewer overflow cannot be excluded. The PFC output from the basin was estimated at $7 \mathrm{~kg} / \mathrm{km}^{2} / \mathrm{yr}$, less than observed for other large European rivers.

\subsection{Plastic debris: first analyses}

Microplastic debris (size $<5 \mathrm{~mm}$ ), plastic fragments and fibers (exceeding the limit of observation at $50 \mu \mathrm{m}$ )

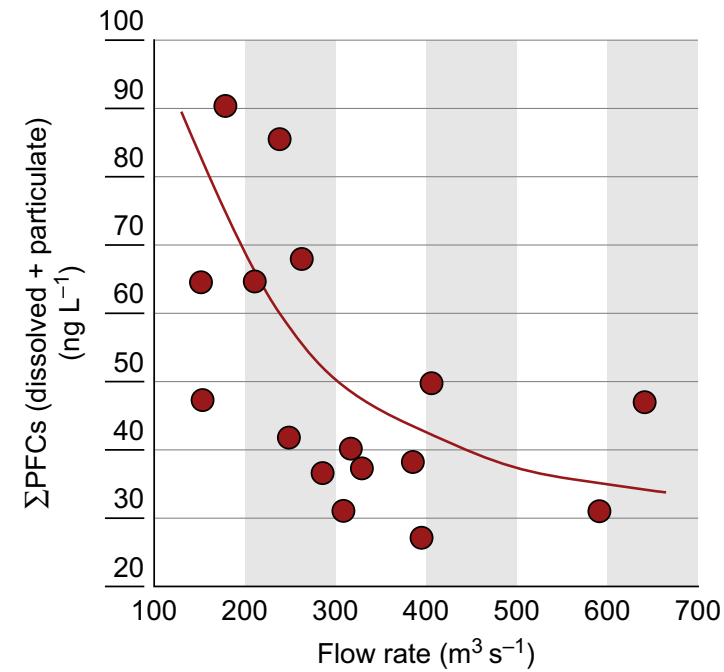

FIGURE 5.2.9 Decrease of total perfluorinated compound concentrations with river discharge in Paris (Labadie and Chevreuil, 2011a,b). 
were analyzed in the Seine (Dris et al., 2015, 2018). First, a large difference in the concentration between fibers and fragments was observed. The mean fiber concentration was found around 45 fibers $\mathrm{m}^{-3}$ while the mean fragment concentration was around 0.54 fragments $\mathrm{m}^{-3}$. For fibers, variability throughout the water column profile and across the river section was assessed and showed that their concentrations were similar over the entire depth of the river, while there was a tendency to concentrate near banks. During a long monitoring campaign on five different sites, only small variations occurred and no direct correlation was found between concentration levels and water flow. For plastic fragments, polyethylene accounted for $50 \%$ followed by polypropylene ( $29 \%$ ), then polystyrene and polyethylene terephthalate (Dris et al., 2015, 2018).

\subsection{Antimony, silver, and thallium}

The growing use of silver (Ag), antimony ( $\mathrm{Sb})$, and thallium (Tl) in the last 15 years resulted in an increasing concern for their environmental impacts. However, there is still limited information on anthropogenic sources and pathways, as well as geochemical behavior in urbanized river basins. In the Seine basin, Ag is one of the best markers found for urban-derived contamination (Froger et al., 2018), with the enrichment factor covering over three orders of magnitude, probably resulting from exceptional plating activities present in Paris in past centuries. In the outlet core, the concentration was highest $(14.3-24.6 \mathrm{mg} / \mathrm{kg}$ ) in the $1960 \mathrm{~s}$ and 1970s (Ayrault et al., 2010). It then gradually decreased to $4 \mathrm{mg} / \mathrm{kg}$ of sediment in 2003. In contrast, $\mathrm{Tl}$ concentrations remain roughly constant throughout the core (median value of $0.86 \mathrm{mg} / \mathrm{kg}$, close to natural background values. Sb contamination (once a coproduct of $\mathrm{Pb}$ contamination) displayed similar temporal trends as Ag. The Ag and $\mathrm{Sb}$ geochemical behaviors (i.e., dissolved/solid partitioning analyzed on an annual basis) are highly contrasted, $75 \%$ and $4.3 \%$, respectively (Ayrault et al., 2013). This last fraction tends to increase in urban parts of the basin, as particulate contamination is driven by the increasing uses of $\mathrm{Sb}$ compounds (flame retardants, brakes, etc.) (Le Pape et al., 2012).

\subsubsection{Pesticide contamination: the barrel of the Danaids}

The assessment of pesticide contamination in rivers greatly depends on monitoring, which requires specific field precautions, monitoring strategies, ad hoc frequencies, and specific analysis. The use of pesticides increased considerably in France from 23,500 tons in
1971 to 63,700 tons in 2009 , and their composition has greatly evolved (Sauvegrain, 1981; UIPP, 2010). In the Seine basin, preliminary regulatory monitoring started in 1976 at a few stations for organochlorinated pesticides only and the occurrence of atrazine and lindane was revealed in the Orgeval River in the same period (Chevreuil, 1978). Three decades later, pesticide assessment officially reported in the national State of the Environment Report (IFEN, 2007) that 450 substances were tested in 2004 in French rivers and 229 of them were quantified at least once. No quantitative assessment of contamination was yet available. Most substances detected were herbicides and their metabolites (atrazine and its metabolite DEA, glyphosate and its metabolite AMPA, diuron, isoproturon, and aminotriazole).

Pesticide use and thus the residues found in surface and groundwaters greatly depend on the target. The inventory of agricultural and urban sources of pesticides in the Marne River basin, at a given period (the 2000s), illustrates this mosaic-like composition: among the 190 substances listed in the agricultural sector (Marne River basin), in addition to the dominant herbicides (isoproturon and tebutame), fungicides (mancozebe, cyprodinil) were also important. Most of the substances detected in rivers are also commonly used in urban areas (diuron, aminotriazole, glyphosate). The pesticide issue is also facing a continuous gradual replacement of one substance by another authorized in agriculture, which is the main user, but also in cities (roads, cemeteries) and infrastructures such as railways.

In the early 2000s, the first comparison of pesticide use, leaks, and exports by a river was made at the scale of the Marne River (Guivarch'-Blanchoud, 2001; Blanchoud et al., 2007). Agricultural uses accounted for $99 \%$ and urban uses for only $1 \%$. The total load of pesticides exported from the Marne River $\left(12,600 \mathrm{~km}^{2}, 2 \mathrm{M}\right.$ inhab.) was estimated at $1.7 \mathrm{mg} / \mathrm{m}^{2} / \mathrm{yr}$. The leakage rate of pesticides, defined by the ratio of the river exported fluxes over total use in the basin ranged about two orders of magnitude in the urbanized basin from $0.1 \%$ for isoproturon and $7 \%$ for diuron (Blanchoud et al., 2004). This reflects the wide variability of river contamination depending on the surfaces treated (impervious surfaces) and the physical and chemical properties of the pesticides, such as volatilization rate, water solubility, and adsorption onto clays and organic matter. Such heterogeneity greatly limits the construction of pesticide modeling, which should be tailormade for each molecule.

In Paris suburban rivers, pesticide contamination mainly originates from storm sewers and WWTPs. Botta et al. (2009) showed that glyphosate and its degradation product (AMPA) were the most frequently detected 


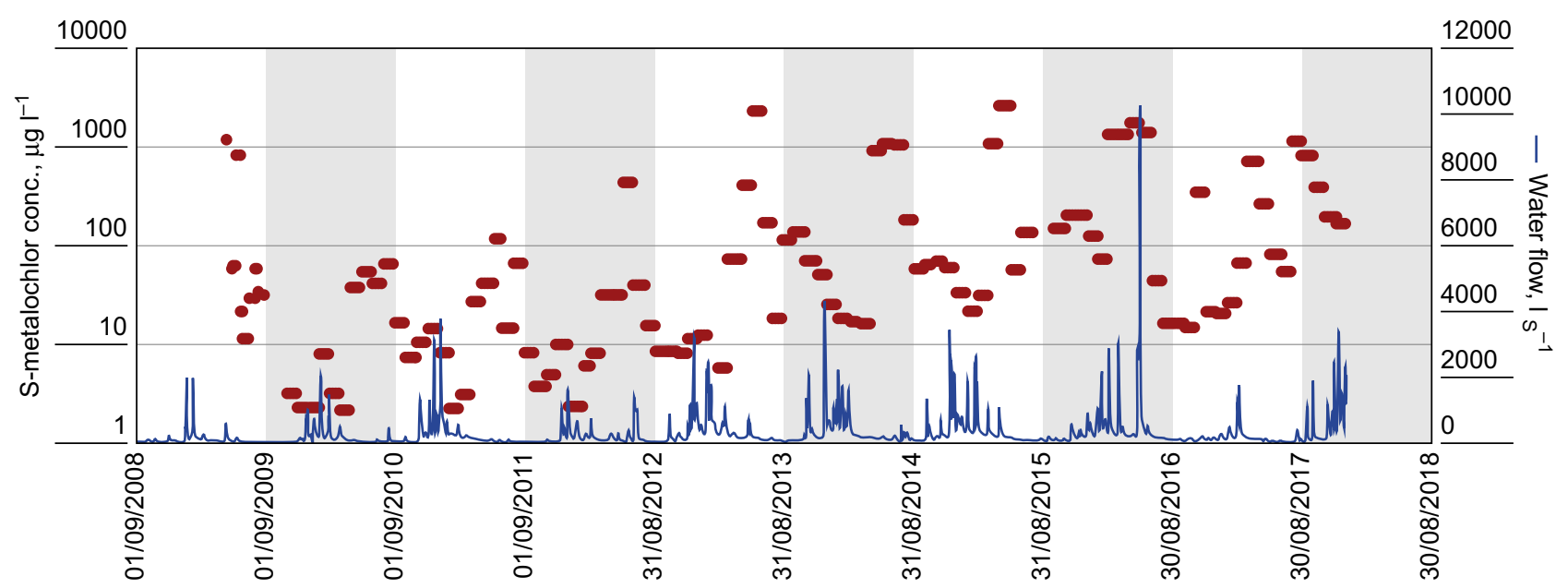

FIGURE 5.2.10 Typical contamination patterns of S-metolachlor $(\mu \mathrm{g} / \mathrm{L})$ in an agricultural stream (Orgeval basin). Average monthly concentrations over a 10-year period. Right y-axis in log scale.

pesticides in the Orge River (see Fig. 5.2.1). After the ban of diuron in 2007, glyphosate was the main herbicide used in urban areas and today sometimes exceeds the European quality standard concentrations of $2 \mu \mathrm{g} / \mathrm{L}$ for a drinking water resource. The annual glyphosate estimated load was $179.5 \mathrm{~kg} / \mathrm{yr}$ at the catchment outlet $\left(950 \mathrm{~km}^{2}\right)$, of which only $1 \%$ was estimated to originate from agricultural sources. The main source was road and railway applications. Glyphosate reached surface water prevalently through storm sewers during rainfall events. Maximum concentrations $(75-90 \mu \mathrm{g} / \mathrm{L})$ were detected in storm sewers just after a rainfall event lasting a few hours, another difficulty of pesticide monitoring. Glyphosate has been regulated from 2019 onwards.

In agricultural basins, the temporal dynamics of herbicide concentrations is mainly related to crop rotation at the farm scale (Schott et al., 2004). To integrate this, average monthly samples weighted by stream discharge from Orgeval stream $\left(104 \mathrm{~km}^{2}\right.$, Brie region, center of the Seine basin, Fig. 5.2.1) and monitored for 10 years. Average monthly concentrations showed a marked seasonal variability over two orders of magnitude, as for Smetolachlor where maximum concentrations were measured in May-June. This variability depended on (1) the application period specific for each pesticide and (2) the time lag between the application date and the first following efficient rainfall. The Orgeval study also showed a rising level of contamination over 10 years, particularly for minimum yearly concentrations, which could be related to growing contamination of soil and the unsaturated zone, drained by tile drains and surficial aquifers (Fig. 5.2.10).

Assessing pesticide contamination is therefore like shooting at a moving target. Today, more than 300 substances and by-products are listed as examined in the Seine basin database in 2014, but only a few of them would exceed, on average, the water quality standard in drinking water (DGS, 2016). The Water Framework Directive's objective to assess the status of each waterbody cannot be fulfilled at the level of Seine waterbodies, as they are defined today at a scale of $100 \mathrm{~km}^{2}$, unless enormous monitoring efforts are deployed or representative waterbodies are selected (rural and urban).

\subsubsection{Biodiversity, biological compartments}

\subsubsection{Microbiological contamination: a pronounced decline in the last 2 decades}

River waters can transport a wide variety of pathogenic microorganisms: viruses, bacteria, and protozoa. The main origin of these microorganisms is the direct and indirect release of human and warm-blooded animal feces into aquatic environments. The health risk for humans related to the presence of these pathogens depends on water use (drinking water production, bathing and recreational activities, irrigation, shellfish harvesting) and on the pathogen concentration in water. In aquatic systems, the detection and enumeration of all pathogenic microorganisms potentially present is difficult due to the large diversity of pathogens, the low abundance of each species, and the absence of standardized methods for the detection of some of them. Even if progress in molecular biology allows detection of increasing numbers of pathogens in a water sample, it is today impossible to base the routine monitoring of microbiological water quality on the direct detection of pathogens. Therefore monitoring is still based on the concept of fecal indicator bacteria (FIB); that is, groups of bacteria that are present in high abundance in feces 
of humans and warm-blooded animals. The main organisms used as bacterial indicators today are fecal (also called thermotolerant) coliforms (FC), Escherichia coli and intestinal enterococci; they are predictors of the health risk associated with water (Edberg et al., 2000). Today, all guidelines for assessing water quality required for different water uses are based on the concentrations of FIBs.

\subsection{Diffuse and point sources of microbiological contamination}

Natural aquatic environments receive fecal microorganisms by diffuse sources of contamination through runoff and soil leaching in rural areas. In studies conducted in the Seine watershed, concentrations of FIBs were determined in headwater streams upstream of any source of domestic contamination to obtain a rough estimate of what levels of contamination were due to runoff waters and soil leaching. These studies showed that the concentrations measured were different depending on the land use of the respective watershed (Fig. 5.2.11). When the catchment area was mainly covered with pastures, streams presented contamination levels one order of magnitude higher than those whose catchment area was covered mainly by forest or crops (George et al., 2004; Garcia-Armisen and Servais, 2007).

Major point sources included the discharge of urban wastewater (raw or treated in WWTPs), industrial wastewater, urban runoff waters collected in a separate sewer, and CSOs. Concerning point sources of contamination, domestic wastewater contains high concentrations of microorganisms of fecal origin. For example, E. coli concentrations in raw sewage are usually around $10^{7}$ per $100 \mathrm{~mL}$ (Servais et al., 2007a; Lucas et al., 2014). Studies on the removal of fecal bacteria in WWTPs located in the Seine watershed usually show, for treatment plants using settling followed by a biological treatment (activated sludge process), a two-log unit reduction of FIBs, corresponding to $99 \%$ removal (George et al., 2002). In WWTPs where a tertiary

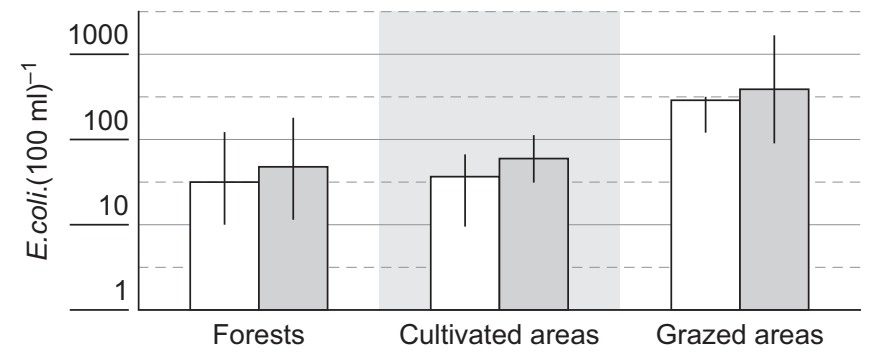

FIGURE 5.2.11 Land use control on fecal contamination. E.coli abundance (log scale) in small streams of the Oise subbasin (clear bars) and Normandy (gray bars) upstream of any point source of fecal contamination. Vertical bars: range between minimum and maximum values. treatment of nitrogen or phosphorus is added, as in most WWTPs today, one can observe an improvement in the removal of FIBs (up to three-log removal) (Servais et al., 2007a; Rocher et al., 2017). The respective importance of each type of source (point vs. diffuse) at the scale of the whole basin was estimated taking into account land use, population density, and type of wastewater treatment. Point sources of FIBs largely dominated the Seine basin (Garcia-Armisen and Servais, 2007).

\subsection{Microbiological water quality in the Seine River over one century}

The microbiological quality of the Seine River in the Paris area was studied since the beginning of the 20th century. Fig. 5.2.12 shows the evolution of the annual average abundance of E. coli in the Seine just upstream from Paris, at the city water intake (Ivry-sur-Seine). Although it is advisable to be cautious when comparing measurements made over a period of a century with methods that have evolved over time, it seems clear that there was a decrease in microbiological quality from the beginning of the century to the 1980s, with maximum deterioration between 1950 and 1980. This was related to a significant increase in the urban population in the Seine basin area upstream from Paris and its generalized postwar sewage collection as well as the implementation of domestic sewage treatment plants, which mostly started after 1970 (Servais et al., 2007b). After the mid-1980s, there was a significant improvement in microbiological quality where annual average levels of E. coli decreased by a factor of 100 between 1985 and today at the drinking water production plant intake at Choisy-le-Roi (upstream from Paris). This improvement was first related to the increasingly widespread installation of WWTPs, such as the Seine-Amont

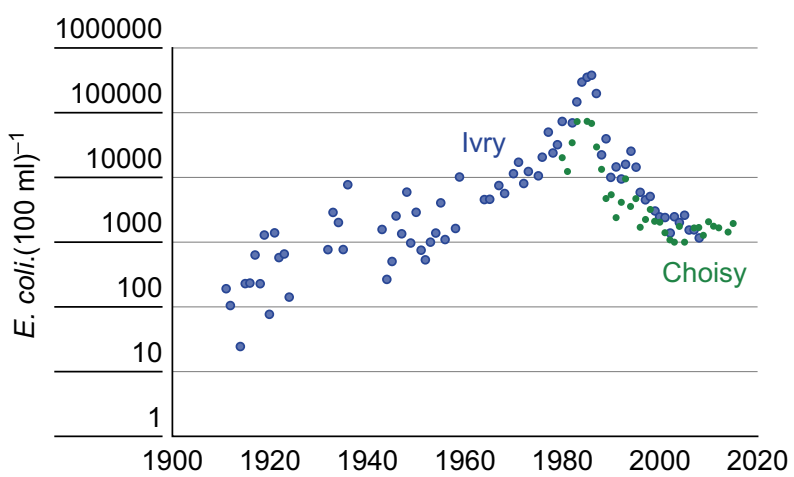

FIGURE 5.2.12 Fecal contamination of the Seine River at Ivry, the historical water intake $2.5 \mathrm{~km}$ upstream from the city limits. Annual average E. coli abundance (log scale): in blue, historical archives at Ivry (data from Eau de Paris), and in green, values measured at Choisy-leRoi (SEDIF-Véolia data), a few kilometers upstream from Ivry. 
WWTP, also located upstream from Paris at Valenton, and then to the improvement of treatment.

In addition, the spatial distribution of fecal contamination was studied along the Seine River at different periods. In 1998, an increase in the number of FC was observed just upstream from Paris due to the outfall of the Seine-Amont WWTP effluents ( $\mathrm{km} \mathrm{-9).} \mathrm{However,}$ the major increase in FC concentration in the Parisian area was due to the outfall of the large Seine Aval WWTP (km 63) downstream of Paris. The outfall of this plant obviously severely damaged the microbiological quality of the river. Downstream from the SeineAval WWTP outfall, FC abundance decreased by two $\log$ units in the Seine, partly because of dilution of river water by the less contaminated Oise River (whose confluence is $9 \mathrm{~km}$ downstream from the outfall). Downstream of the Oise confluence to the estuary, $140 \mathrm{~km}$ along the lower Seine, a large reduction of FC abundance was observed. In agreement with the longterm data, the measured FC abundance profile in 2008 showed improvement in microbiological quality, especially downstream from the Seine-Aval WWTP, as a result of large construction works conducted in the six Parisian WWTPs since the beginning of the 21st century.

Fecal contamination can be different during wet weather. Paris and its surroundings are mainly drained by a combined sewer network in which domestic wastewater is mixed with urban runoff water during rain events. When rainfalls are intense, the transport capacity of the sewer system to reach WWTPs can be saturated. In such cases, CSOs occur, resulting in a direct discharge into the river of a mixture of wastewater and runoff water. The consequence is a substantial increase in the concentrations of pathogens and FIBs downstream from the outfall. Passerat et al. (2011) studied the impact of an intense CSO event occurring in summer at one of the main CSO outfalls in the Seine River at Clichy $(\mathrm{km}$ 23) on the microbiological contamination of the river. Directly downstream from the CSO outfall, FIB concentrations in the impacted water mass of the Seine exceeded the usual dry weather concentrations at the same station by two orders of magnitude. With regards to microbiological river water quality, decreasing the frequency and the intensity of CSOs is currently one of the major challenges of wastewater management in the Paris area. It must be noted that this problem stems directly from the sewage system designed in the Second Empire (1852-70), a good example of inherited environmental issues in river basins, also found in other European cities (Lestel and Carré, 2017).

\subsection{Pathogenic microorganisms}

In recent years, a number of studies have investigated the presence of major pathogens in rivers in the Paris area. Mons et al. (2009) evaluated protozoan contamination of the Seine and Marne Rivers; Giardia cysts and Cryptosporidium oocysts were found in $94 \%$ and $46 \%$, respectively, of the 162 river samples collected. Mean concentrations of Giardia at the different stations sampled ranged between 12 and 38 cysts $/ 10 \mathrm{~L}$, while for Cryptosporidium the range was between 0.3 and 36 oocysts $/ 10 \mathrm{~L}$. The authors hypothesized that the origin of the contamination by protozoa was agricultural practices and possible dysfunction of WWTPs during periods of heavy rainfall. More recently, three virus families were detected in the Seine using quantitative PCR: noroviruses GI and GII, adenoviruses and rotaviruses (Prevost et al., 2015). Other viruses were present but with lower recovery frequencies or concentrations. WWTP effluents were identified as the main source of viral contamination of the Seine (Prevost et al., 2015).

\subsection{Modeling microbiological contamination in the Seine River drainage network}

The source and dynamics of fecal bacteria in the Seine drainage network were modeled using a simple module, which includes the FC concentration as the state variable added to the hydroecological Riverstrahler see Section 5.2.4.1 and Fig. 5.2.2) that describes the functioning of large rivers (Servais et al., 2007a,b). Nonpoint sources of FC were calculated on the basis of land use in subwatersheds generating a base level of FC due to soil leaching attributed to base flow. Point sources of FC associated with wastewater inputs are then added, calculated on the basis of the capacity and type of treatment for each WWTP (about 2000) in the Seine watershed. Finally, the model represents in-river processes controlling the fate of FC, including decay (first-order rate, depending on temperature) and settling. Model calculations were compared to field FC data to validate the model for a number of well-documented situations.

The Riverstrahler model can calculate the distribution of FC in the whole Seine network (see Section 5.2.4.1). For a summer situation, low FC concentrations were found in some headwater streams indicating an excellent/good microbiological quality. These streams were characterized in summer by a significant contribution of low contaminated groundwaters and by the absence of point source wastewater contamination. Most of the agricultural headwater streams in the watershed had FC numbers between 100 and 2000 per $100 \mathrm{~mL}$, which resulted from surface runoff in rural areas. Many stretches of intermediate stream order $(2-5)$ rivers also belonged to the category of low FC concentrations. Degraded (FC numbers $>2000$ per $100 \mathrm{~mL}$ ) and very degraded (FC numbers $>10,000$ per $100 \mathrm{~mL}$ ) microbiological water quality was observed in the Seine reach downstream from Paris (see above) as well as in some small urban streams, mainly in the Paris area. In areas with a high population density, the release of large 
volumes of treated wastewaters in streams having a limited dilution capacity can explain the high level of fecal contamination (Servais et al., 2007a,b).

\subsubsection{Heterotrophic and autotrophic bacteria, and oxygen patterns in the lower Seine}

In 1964, when the Seine-Normandy Basin Water Authority (AFBSN, now AESN) was created (together with five other agencies for each of the largest water districts in France), the major problem identified in the basin concerned a strong summer oxygen depletion downstream from Paris related to urban effluents directly discharged into surface waters or incompletely treated, over a $60-\mathrm{km}$ sector. Downstream of the confluence with the Oise (see Fig. 5.2.1), the river had oxygen concentrations at levels acceptable for aquatic life. The understanding and modeling of this oxygen sagcurve have been one of the first research topics of the PIREN-Seine program.

\subsection{Heterotrophic bacteria and organic matter degradation}

Heterotrophic bacteria activity and its effects on the degradation of discharged organic matter by WWTP effluents in the Seine are represented by two types of bacteria according to their size and specific growth rates (Garnier et al., 1992a, 1992b; Servais and Garnier, 1993). Wastewater effluents were therefore considered as a source of bacteria. Furthermore, in the early 1990s, the organic matter under its different classes of biodegradability (Billen, 1991; Servais et al., 1995), together with bacterial biomass and production rate (Servais and Garnier, 1993) were added to the model. This approach breaks with the classical one by Streeter and Phelps (1925), where organic matter degradation was represented by a simple first-order kinetic equation. The bacterial biodegradation module makes it possible to accurately reproduce the evolution of oxygen levels of the Seine River at Paris mostly impacted by domestic wastewaters, whose treatments have been impressively improved (Billen et al., 2001; Garnier and Billen, 2016) (see Sections 5.2.5.2 and 5.2.8.3).

\subsection{Nitrifiers and ammonia levels}

Wastewater effluents have long been an important source of ammonium and nitrifying organisms in river systems with human impacts. Nevertheless, due to their lower growth rate compared to heterotrophic bacteria, their impact is delayed further downstream (Brion and Billen, 1998; Brion et al., 2001). A module of nitrifying bacteria and ammonium oxidation was also implemented in the Riverstrahler model (Brion and Billen, 1998) as well as associated $\mathrm{N}_{2} \mathrm{O}$ as an intermediate of nitrification (Garnier et al., 2007). For decades until 2007, a second oxygen depletion was observed, $150-200 \mathrm{~km}$ downstream from the first oxygen minimum caused by Parisian effluents (Aissa Grouz et al., 2015). Molecular ecology methods showed that the major lineage-6a of ammonia-oxidizing bacteria (AOB) (Nitrosomonas oligotropha and Nitrosomonas ureaelike bacteria) introduced by WWTP effluents, survived and might have grown in the receiving medium far downstream (Brion and Billen, 2000; Cébron et al., 2004). When the WWTPs were upgraded for nitrification of ammonia in 2007, the ammonia profile was greatly modified, and a tenfold decrease was observed; the model correctly simulated this major change in water quality (Aissa Grouz et al., 2015). Recent research on the nitrifying community (Cazier, 2015), following the upgrade of nitrification in WWTPs, confirms its higher abundance in effluents (by a factor of 10) than in river water, with nitrite-oxidizing bacteria greatly dominating AOB, Nitrospira characterizing WWTP effluents and Nitrobacter the river water (Fig. 5.2.13).

Residual loads released by Paris WWTPs into the Seine have been progressively reduced by a factor of 10 to meet EU regulations such as the WFD, since the 1990s for organic matter and since 2007 for ammonium. As a consequence, oxygen depletions, immediately downstream of the discharge of the WWTP effluents of Paris and farther in the fluvial estuary are considerably reduced today.

\subsubsection{Aquatic vegetation}

Understanding vegetation development at any place in the river continuum (Vannote et al., 1980) requires an upstream-downstream perspective. In the Seine

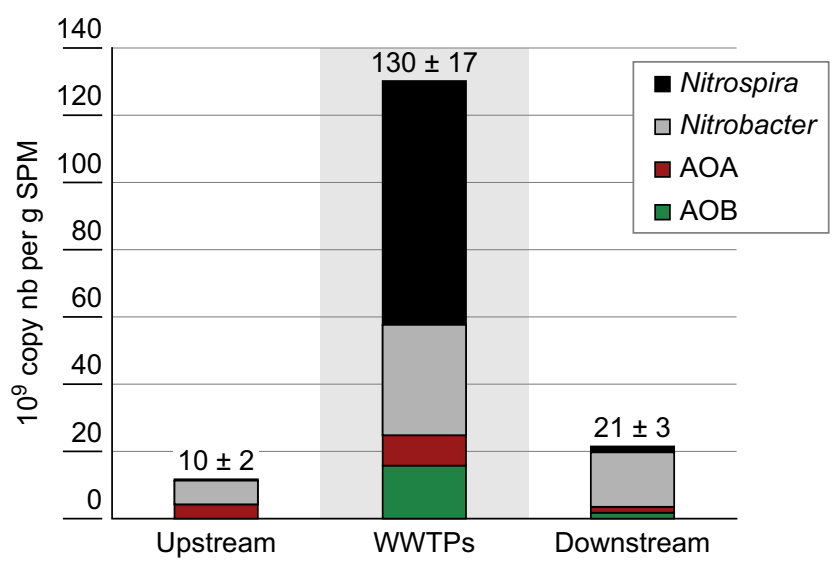

FIGURE 5.2.13 Average total abundance of the nitrifier genes in copies per $g$ of dry SPM (mean and standard deviation) and the relative contributions of the different nitrifying groups in the effluents of the Seine-Aval and Seine-Amont WWTPs and in the Seine at Asnières (Upstream) and Poissy (Downstream) (Cazier, 2015). AOA, ammoniaoxidizing bacteria; $A O B$, ammonia-oxidizing archea. 
basin, this has been done following a stream order approach, focusing on vegetal biomass and dynamics that are part of the general in-stream model components of the river system.

\subsection{Phytoplankton}

Phytoplankton in the Seine, as in many rivers, is mostly dominated by diatoms ( $45 \%$ of the genera and abundance), which form high-amplitude peaks in spring as long as silica is not exhausted compared to phosphorus, the limiting nutrient in the river (Garnier et al., 1995), with nitrogen in large excess in this intensively cropped basin. Centric diatoms are frequent in spring (Stephanodiscus, Aulacoseira, Cyclotella spp, etc.) and associated with pennates (Fragilaria, Melosira, Nitzschia spp). Chlorophyceae represent $30 \%-35 \%$ of the genera and abundance (Monoraphidium, Coelastrum, Scenedesmus spp). The rest of the phytoplankton community is represented by Cryptophyceae (Cryptomonas spp.) and occasionally by Chrysophyceae (Dinobryon spp), Dinoflagellates (Peridinium spp) and Cyanobacteria. No major change in phytoplankton composition was observed between microscopic counts made in the early 1990s, as well as the counts from 2010 to 2014, although a drop was reported in the abundance and biomass using sensors, especially related to a decrease in Chlorophyceae (Escoffier et al., 2018).

\subsection{Macrophytes}

Macrophyte biomass relies on local illumination depending on self-shading, shading by shoreline vegetation (tree height, stream width, sun position, stream orientation) and hydromorphology conditioning (Dufayt, 2000). Maximum biomass is generally observed from April to July. Airborne photographic shoots carried out in 1999-2000 along a 120-km stretch of the Marne River were used to estimate the spatial coverage of macrophytes from $0 \%$ to $17 \%$ ( $4 \%$ on average, Photo 5.2 .3 ) by calibrating the percentage of coverage with biomass determined from samples (i.e., $0-60 \mathrm{~g}_{\mathrm{dw}} / \mathrm{m}^{2}$, and 14 $\mathrm{g}_{\mathrm{dw}} / \mathrm{m}^{2}$ on average, with $1 \%$ corresponding to 3.5 $\mathrm{g}_{\mathrm{dw}} / \mathrm{m}^{2}$ and $1.05 \mathrm{~g} \mathrm{C} / \mathrm{m}^{2}$ ). Beyond all expectations, the nutrient-enriched Marne River (nonnavigated stretch) was not highly colonized by fixed vegetation due to shoreline trees, $70 \%$ on average along the survey area (Garnier et al., 2001). Macrophyte biomass was generally abundant in sectors when trees were sparse, as is often the case near bridges.

\subsection{Periphyton}

Periphyton is by definition a complex community of organisms (algae associated with organic and inorganic bacteria, fungi, animals and detritus), attached to a substrate, organic, inorganic, living or inert. Periphyton biomass develops between April and July. Its control factors are local conditions of illumination of the watercourse and river hydrodynamics; it may be detached during floods. Sampling campaigns in a subbasin of the Marne River determined biomass from 12 to 375 $\mathrm{g}_{\mathrm{dw}} / \mathrm{m}^{2}$ (mean, $125 \mathrm{~g}_{\mathrm{dw}} / \mathrm{m}^{2}$ ) over the 2001 summer period (Flipo et al., 2004, 2007b). In this fourth stream order, up to $1.4 \mathrm{tC} /$ day were possibly exported during a flood event (Flipo et al., 2004).

\subsubsection{Microfauna}

In the slow-flowing lower Seine and in the fluvial estuary, microcrustaceans were only observed during the low-water stage (Akopian et al., 2001), after a distance making it possible to complete their slow reproductive cycle. In the other Seine River reaches, zooplankton does not control phytoplankton biomass as commonly observed in stagnant systems of the basin (Garnier et al., 1995), although it can influence phytoplankton composition (Gosselain et al., 1994, 1998). Reservoirs of the Seine $300 \mathrm{~km}$ upstream from Paris are particularly favorable for the development of these large filtering organisms and cilia (Tintinnopsis lacustris) (Akopian, 1999;
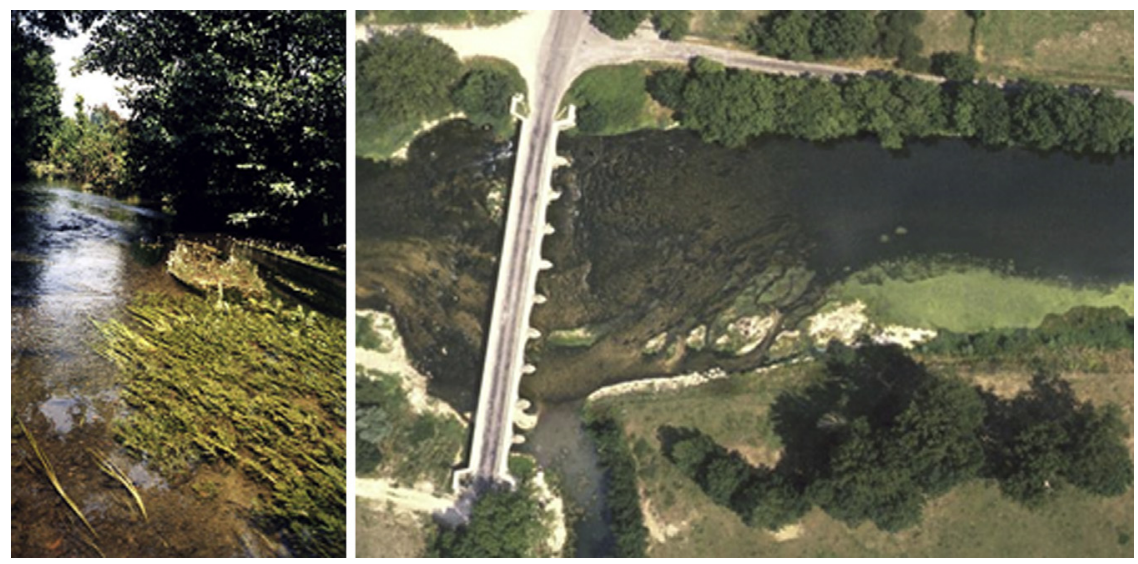

PHOTO 5.2.3 Macrophyte cover in the Marne River for stream orders 4 (left) and 6 (right). Credit: Envergure c/o PIREN-Seine. 


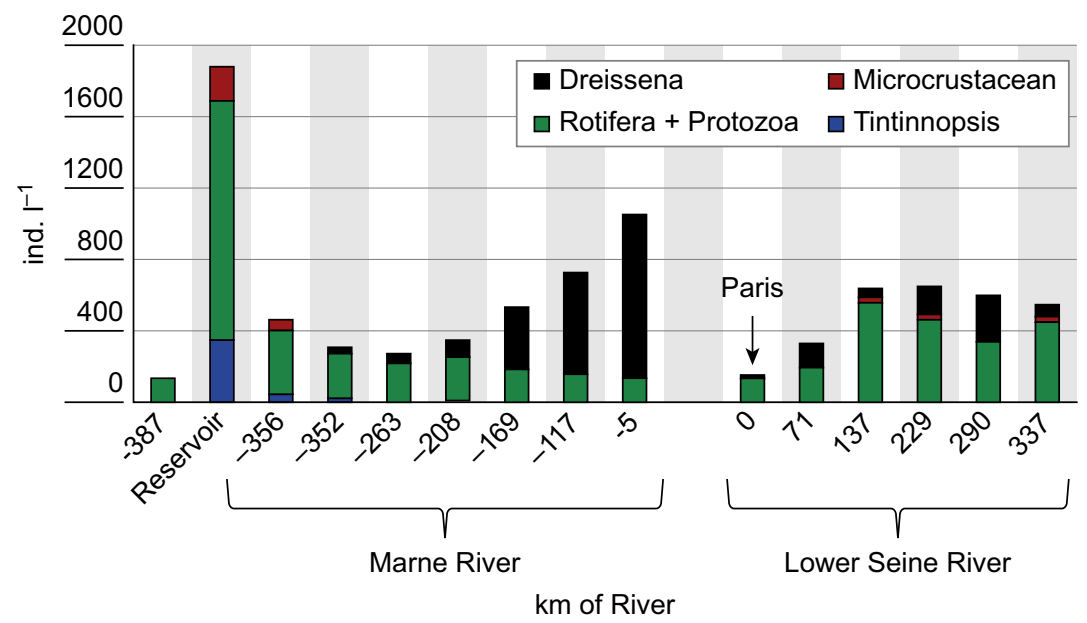

FIGURE 5.2.14 Longitudinal profile of main zooplankton groups (Dreissena polymorpha larvae, Rotifera and Protozoa, Microcrustacean and Tintinnopsis lacustris), over $750 \mathrm{~km}$ from the upper reaches of the Marne River ( $\mathrm{km}-387$ to 5) to the lower Seine and estuary (km 0 to 337). The abundance averages (ind/L) are given for each river section. Rotifers dominate over $150 \mathrm{~km}$ downstream of the Marne Reservoir, then again downstream of Paris. The reservoir is diverted from the Marne River.

Akopian et al., 2002) and are known to be feeding areas for fish.

Another component of zooplankton is lamellibranch larvae, generated by invasive benthic filter-feeders, Dreissena polymorpha, which colonized the Seine basin in the 1980s, like other water bodies in Europe and North America (Testard, 1990, 1992; Khalanski, 1997). The ecological effect of this invasive Dreissena has been well documented in the Seine system via fluxes of larvae (Akopian et al., 2001, Fig. 5.2.14).

Zooplankton dynamics are represented in the Riverstrahler model under two groups, fast- and slow-growing (e.g., rotifers and microcrustaceans, respectively (Garnier and Billen, 1993). In addition, Dreissena larvae are incorporated into the modeling work by taking into account the adult filtering activity represented as a constraint, with a constant bottom biomass and filtration rate that depends on temperature (Garnier et al., 1998, 1999).

\subsubsection{Fish and their historical evolution: controlling factors}

\subsection{General historical evolution}

In the 2010s, the Seine basin fish fauna comprised 59 species including 10 diadromous species, three of them only occurring in the estuary (Osmerus eperlanus, Platichtys flesus, Liza ramada). In the early 1800 s, the original fish fauna of the Seine basin was about 30 species, a limited number resulting from the effect of glacial periods during the Quaternary, as in other West European basins. The current composition of fish results from a balance between newly introduced species and loss of native species, particularly migratory fishes (Belliard et al., 2009a). Ironically, fish biodiversity today is higher than it was 200 years ago, based on historical records, for which no bias is expected given the accurate knowledge we have about fish species, freshwater fish being an important source of food in the past (Belliard et al., 2018).

23 species out of 59 are nonnative and originate from indirect or voluntary introductions. With the development of waterways since the 17th century, the Seine basin has been connected with neighboring basins (Rhone, Mosel, Rhine), favoring the dispersion of aquatic species. At least two species, ruffe (Gymnocephalus cernua) and nase (Chondrostoma nasus) colonized the Seine River during the 18th and 19th centuries. Similar colonization processes are suspected for two species recently observed in the basin: the asp (Leuciscus aspius) and round goby (Neogobius melanostomus). North American species (Ameiurus melas, Lepomis gibbosus, Oncorhynchus mykiss, for example) were voluntarily introduced for recreational fisheries or aquaculture purposes. The last species introduced are wels catfish (Silurus glanis) during the 1980s and stone moroko (Pseudorasbora parva), which remains confined in some locations. Today, authorities no longer consider introduced fish species as invasive in the Seine River basin.

At the beginning of the 20th century, several fish species (all migratory) disappeared from the Seine River, following the construction of navigation dams and strong degradation of water quality in the lower Seine, from Paris to the estuary. European sturgeon (Acipenser sturio) has been declared extinct, whereas recently, the return of some migratory species was observed (Salmo salar, Alosa spp, for example) (Belliard et al., 2009b), although these species are still threatened. 


\subsection{Temporal and spatial fish assemblage changes}

Besides two general trends, (1) the dramatic decline in the early 1900s, followed by a recent $(>1990)$, but still partial, return of diadromous fish and, (2) the gradual development of nonnative species, the fish assemblage has evolved differently in various areas of the Seine ba$\sin$. Historical analysis over the last 150 years based on 29 sites distributed throughout the Seine basin indicated that long-term changes in fish assemblages have differed. In smaller streams and headwaters, the fish assemblage showed signs of improvement, with a decreasing human population and generalized sewage treatment for villages exceeding 2000 inhab. (Belliard et al., 2018). In larger rivers where urban growth is noted along river corridors, fish assemblages have been negatively affected; from 1950 to 2000, the proportion of tolerant or generalist taxa increased.

Downstream of Paris, the fish assemblage evolved in a specific manner during the last century (Boët et al., 1999). In the 1960s, water quality was at its maximum deterioration, with very low dissolved oxygen content, and only tolerant species such as roach (Rutilus rutilus), bream (Abramis brama) and carp (Cyprinus carpio) were able to live in such conditions. With the improvement of wastewater collection and treatment, some species returned in the 1990s. Also, massive fish kills of all species were observed during summer overflows of Paris combined sewers, resulting from rain events, a structural impact of the sewer system, which has been observed since the construction of Paris sewers in the 1870s (Dmitrieva et al., 2018); these events lasted until the mid-1990s. Nowadays, the fish assemblage has progressively recovered in this reach and 21 species are regularly encountered (Azimi and Rocher, 2016).

\subsection{Fish dynamics in the upper Seine River floodplain (Bassée)}

The main Seine River floodplain, called La Bassée, is located 100-km upstream from Paris (see Fig. 5.2.1). The lower Bassée area was partly channelized in the 1970s for navigation purposes, whereas the upper part remained quite natural. Channelization had an impact on perifluvial wetlands, which were important fish reproduction areas. Many natural backwaters (29 sampled in La Bassée, see Fig. 5.2.1) generated by the lateral mobility of the channel and variously connected to it were destroyed and artificial wetlands were created, namely gravel pits (old and recent) and cut-off meanders (shallow and deep). These artificial wetlands did not replace the original natural backwaters in their role for fish reproduction: young fish densities and species richness were still lower. The functional diversity of young fish was also lower in artificial backwaters that were marginally connected with the main channel and where macrohabitats were not favorable for young fish (Tales and Berrebi, 2007).

In addition, floodplain habitats are important for pike (Esox lucius) reproduction. This species needs inundated grasslands to breed. Its natural conservation depends on regular flood occurrence and the presence of connected suitable habitats. Channelization reduced the frequency of flooding in Bassée and wet grasslands, which were very suitable spawning grounds for pike, have decreased. Fish habitat heterogeneity was also reduced after channelization. This affected rheophilic species, mainly nase (C. nasus) and barbel (Barbus fluviatilis), that use running habitats for feeding. To achieve their life cycle, both the amount and location of running water habitats matter, in addition to habitat patch size and connectivity (Le Pichon et al., 2016). These findings enhance the need to preserve remnant natural floodplains to support diverse and functional fish assemblages in the Seine River.

\subsubsection{Biogeochemistry: nutrients and eutrophication}

Beyond the separate examination of its biotic and nonbiotic components, a biogeochemical view of the river system offers a useful approach to synthesize the complex interactions that are the basis of its functioning. It addresses the issues of eutrophication and nitrogen contamination and the effect of climate change on ecosystem function. It can also be used to design scenarios for the future of the basin.

\subsubsection{Eutrophication in the Seine basin: successful $\mathrm{P}$ reduction from urban sources}

In the 1970s, when oxygen depletion was a major issue in the lower Seine, phytoplankton eutrophication was also a problem in the upper Seine and in major upstream tributaries, Marne and Oise, with chlorophyll peaks up to $200 \mu \mathrm{g} / \mathrm{L}$ (Dessery et al., 1984). These algal blooms caused major treatment problems for drinking water production (Billen et al., 1984) and built an organic load, which contributed to severe oxygen depletion in lower sectors. Whereas chlorophyll concentrations frequently reached more than $150 \mu \mathrm{g} / \mathrm{L}$ in the 1990s, peak values are now $<50 \mu \mathrm{g} / \mathrm{L}$ after a strong reduction in phosphorus at point sources (Garnier et al., 2005; Passy et al., 2016; Aissa Grouz et al., 2018). Upgraded phosphorus treatment in WWTPs resulted in a 

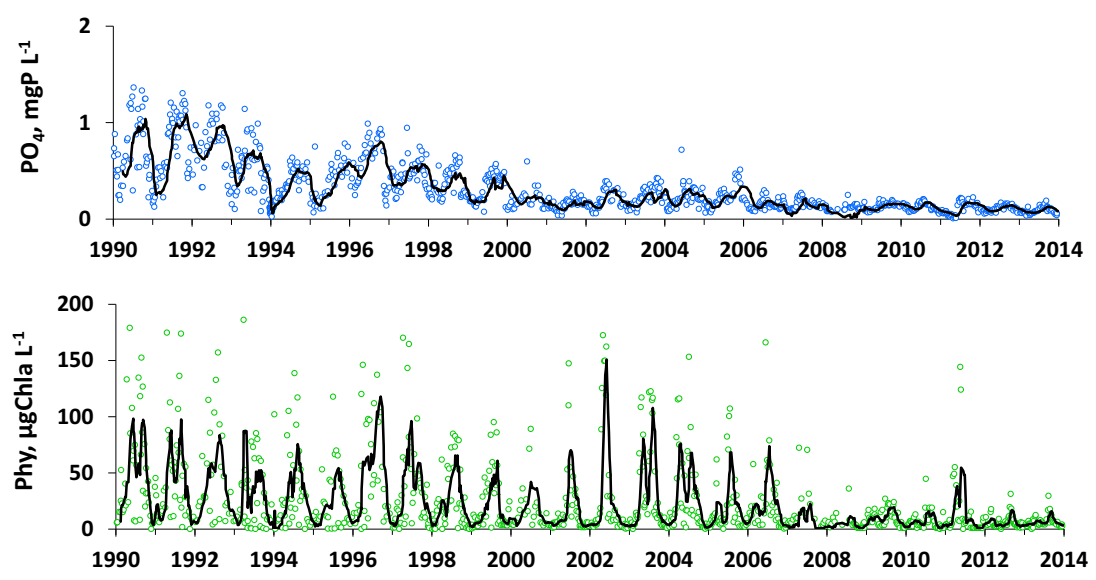

FIGURE 5.2.15 Interannual observed variations of phosphate concentrations $\left(\mathrm{PO}_{4}{ }^{3-}\right)$ and phytoplankton biomass (in terms of chlorophyll $a$ concentrations, Chla), at Poses, the outlet of the Seine basin. Arrows indicate a new dephosphatation step at the Seine-Aval WWTP in 2000 and another one from 2007. Open circles are observations and the solid line is 12-month moving average.

spectacular decrease in phosphate concentrations, with a first step in 2000 and a second one in 2010 (Passy et al., 2013; Aissa Grouz et al., 2018). Due to the nonlinear response of phytoplankton to phosphorus concentrations, the reduction in point sources became visible only after the second step of treatment, when phosphates reached a limitation concentration for algae; that is, around the half-saturation constant (of about $50 \mu \mathrm{g} \mathrm{P} / \mathrm{L}$ ) (Fig. 5.2.15).

In addition to major phytoplankton groups, phytoplankton modeling across stream orders takes into account the dilution rate and nutritional and light/ temperature conditions from upstream to downstream (Garnier et al., 1995; Garnier and Billen, 2016). Major factors controlling phytoplankton development from upstream to downstream are indeed nutrient inputs and dilution rates (bottom-up), although the top-down role of filtration (rotifers, microcrustaceans, Dreissena) can be temporarily significant in some sectors. Interestingly, phytoplankton biomass can only develop when its growth rate exceeds the dilution rate by lateral discharge, which only occurs in stream orders higher than 4-5 in the Seine River, from the early spring period after winter high waters, a typical feature of the pluviooceanic regime of the basin.

\subsubsection{Climate change impacts}

Assuming reduced spring and summer discharge with climate change, we can expect a double positive impact on phytoplankton development through (1) an increase of phosphorus concentration by the reduced dilution of wastewaters, despite constant point source fluxes, (2) enhanced growth rates upstream, and (3) extended periods of growth (Raimonet et al., 2018;
Garnier et al., 2018b). In addition, diffuse phosphorus sources from the erosion of overfertilized agricultural soils presently are in the same order of magnitude as $\mathrm{P}$ point sources (Garnier et al., 2014a). Phosphorus losses by erosion, likely to increase under conditions of increased runoff during storm events, must be prevented.

Together with $\mathrm{P}$, DSi can also be a limiting nutrient for diatom growth. DSi essentially originates from the natural weathering of soils (Sferratore et al., 2006). It is taken up by freshwater diatoms as long as the stoichiometric Si:P ratio does not fall below $38\left(\mathrm{~g}: \mathrm{g}^{-1}\right.$ ) (Conley et al., 1989). When DSi is exhausted, a shift in the algal community, from diatoms to nondiatoms, is observed. Whereas diatoms, especially centric ones, are palatable algae easily transferred through the trophic network, nondiatoms might lead to harmful large algal colonies or even toxic algae.

Taking into account the high $\mathrm{N}$ concentrations in Seine waters (five to eight $\mathrm{mg} \mathrm{N} / \mathrm{L}$ ) with respect to the half-saturation constant (on the order of $14 \mu \mathrm{g} \mathrm{N} / \mathrm{L}$, Reynolds, 1984), nitrogen cannot be a limiting element for photosynthesis, especially in the intensive agricultural Seine basin. However, high values of $\mathrm{N}$ concentrations currently found in surface waters, largely exceed the range of $1.5-2 \mathrm{mg} \mathrm{N} / \mathrm{L}$ above which biodiversity of vegetal (James et al., 2005) and animal (Camargo et al., 2005) aquatic communities is threatened.

\subsubsection{Nitrogen contamination}

\subsection{Contamination in the basin}

The treatment of the organic matter in WWTPs of the Seine basin led to a first reduction of ammonium in the 
late 1990s. However, only appropriate treatment of nitrification allowed the basin management institutions to decrease ammonium to values that significantly reduced nitrification in the lower Seine and therefore oxygen depletion at the outlet of the Seine and its estuary (Fig. 5.2.16). Nitrite also decreased similarly to the ammonia pattern. Nitrate concentration, mainly coming from diffuse agriculture sources, increased at the basin outlet by a factor of 2.5 from the turning point of agriculture practices in the 1960s and mid-2000s (Billen et al., 1998; Billen and Garnier, 2000), has stabilized at this time and decreased since 2012 (Fig. 5.2.16). It is difficult to know whether this recent change could be attributed more to denitrification implemented at WWTPs in 2012, following nitrification in 2007, or to efforts made in agricultural practices: recent decrease in mineral fertilization from 180 to $150 \mathrm{~kg} / \mathrm{ha} / \mathrm{yr}$, fertilizer application split into three instead of a single application (COMIFER, 1996), intercrops (fourth action plan of July 1, 2009, following the nitrate directive 91/676/CEE) and management of grass strips (Cf. Grenelle Environment no. 2009-967 of August 3, 2009).

Despite these efforts in agricultural practices, nitrate concentrations in drained waters remained high and have led to groundwater contamination (a concentration higher than the threshold of $50 \mathrm{mg} \mathrm{NO} / \mathrm{L}$, that is, $11.29 \mathrm{~N}-\mathrm{NO}_{3} / \mathrm{L}$, Fig. 5.2.17A, B), the regulatory level in the EU and France for drinking water supply. Because river discharge during low flows originates from groundwater, this increase is also found in river waters (Fig. 5.2.17C).

\subsection{Nitrate input to coastal zones and its consequences for marine eutrophication}

Whereas nitrogen cannot be an issue for eutrophication in the Seine network because concentrations are far above the level of limitation, this is not the case for coastal eutrophication. France has been convicted several times by the EU court for not reducing its $\mathrm{N}$ fluxes, which are the cause of coastal eutrophication in the Seine Bight, but also in the English Channel and Southern North Sea coastal zone, as sea currents are directed north (Passy et al., 2016; Lancelot et al., 2011; Menesguen et al., 2018). Coastal eutrophication takes various forms depending on the geographical area, toxic Dinophysis prevails in the Seine Bight and mucilaginous Phaeocystis in the north of France and Belgian coasts. It is typically related to a nutrient imbalance regarding the requirements of algae ( $\mathrm{N}$ in excess to $\mathrm{Si}$ and $\mathrm{P}$, and a rather good balance between $\mathrm{P}$ and $\mathrm{Si}$, since the decrease in P fluxes from WWTPs, Billen and Garnier, 1997).

Taking into account nutrient requirements for algae, according to the Redfield ratio (Redfield et al., 1963), an indicator of coastal potential eutrophication (ICEP) has been developed (Billen and Garnier, 2007) and applied at large scales (Garnier et al., 2010; Billen et al., 2011; Romero et al., 2013). It represents the amount of P or nitrogen $(\mathrm{N})$ delivered at the outlet of rivers in excess over silica requirements and expresses the potential for the new production of nonsiliceous algae sustained by river nutrient delivery. It is converted into equivalent carbon fluxes by the unit of watershed area $\left(\mathrm{kg} \mathrm{C} / \mathrm{km}^{2} /\right.$ day) for an interbasin comparison of N-ICEP and P-ICEP
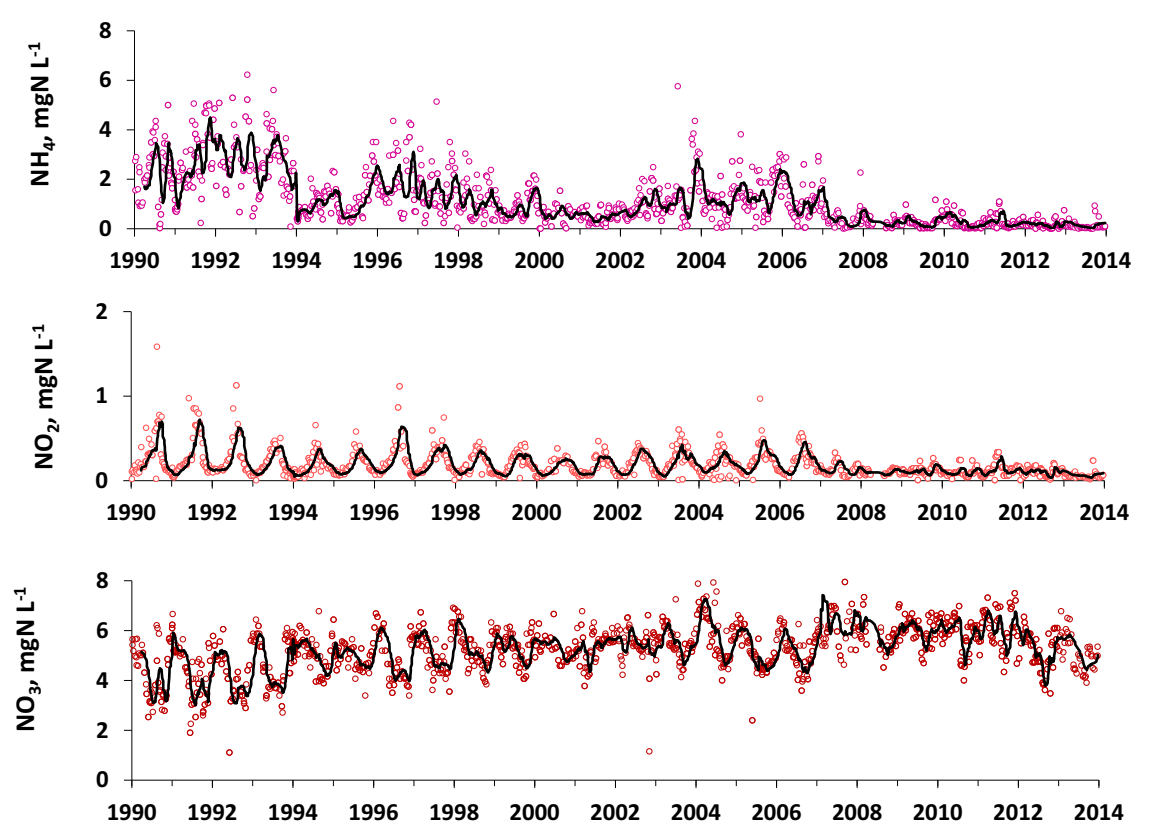

FIGURE 5.2.16 Interannual variations of ammonium concentrations $\left(\mathrm{NH}_{4}{ }^{+}\right)$, nitrite $\left(\mathrm{NO}_{2}{ }^{-}\right)$and nitrate $\left(\mathrm{NO}_{3}{ }^{-}\right)$at Poses, the outlet of the Seine basin. Arrows indicate ammonia nitrification at Seine-Aval WWTP in 2007 and denitrification in 2011. Open circles are observations and solid line is the 12-month moving average. 
(A)

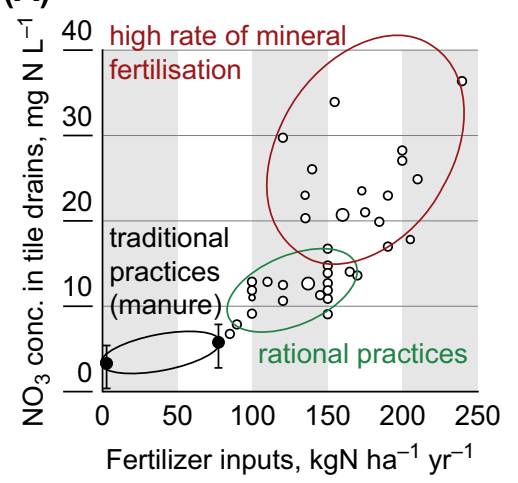

(B)

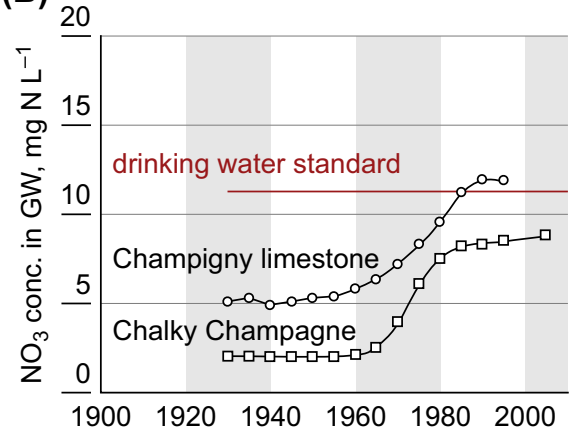

(C)

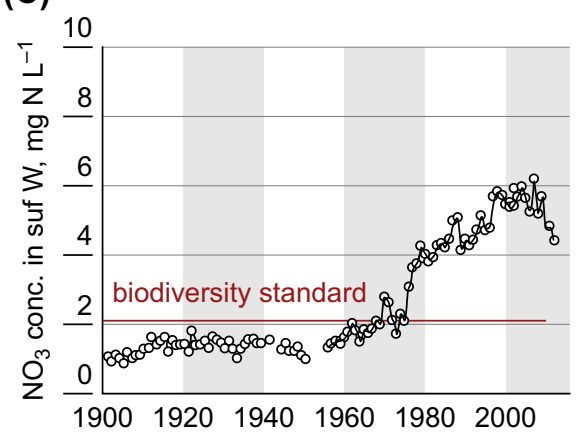

FIGURE 5.2.17 (A) Nitrate $\left(\mathrm{NO}_{3}{ }^{-}\right)$concentration in tile drains as a function of fertilization. (B) $\mathrm{NO}_{3}{ }^{-}$concentrations increase over the long term in groundwater (GW). (C) Long-term $\mathrm{NO}_{3}{ }^{-}$concentration in surface water (surf. W) at Ivry-sur-Seine, upstream from Paris.

and expressed as an average daily value. The ICEP indicator can be calculated from observations (Romero et al., 2013) or modeled for the reconstruction of past situations as well as for prospective scenarios (Billen et al., 2007; Garnier et al., 2018a,b).

\subsubsection{Scenarios to improve nutrient-related water quality in the river and its coastal zone}

The Riverstrahler model is a powerful research tool used to explore a wide range of scenarios (Garnier et al., 2018a,b). As far as nutrients are concerned, nitrogen remains the major problem in the watershed and in the coastal zone. To protect the water resource from nitrate contamination in the Seine Basin and prevent coastal eutrophication, several curative or preventive measures have been considered (Garnier et al., 2014b, 2016).

\subsection{Curative measures}

Among the curative measures, denitrification is an interesting one. Major sites where this process occurs along with the land to sea continuum are soils, riparian zones and benthic river sediments (Thouvenot et al., 2007; Billen et al., 2018a). Approximately $40 \%$ of the nitrate fluxes entering reservoirs of the Seine are also eliminated through benthic denitrification (Garnier et al., 1999), as is the case in sand-pit lakes in the Seine basin (Garnier et al., 1992b; Schanen, 1998). As reservoirs only intercept a minor part of the upstream basin, their role at the basin level is limited (Garnier et al., 2000). Similarly, the rehabilitation role of the thousands of ponds that existed 250 years ago on the Cassini map, which have been drained since the early 19th century to increase the cropping area, would not decrease the nitrate flux enough to reduce coastal eutrophication (Passy et al., 2013).

\subsection{Preventive measures}

Another preventive way of reducing nitrogen loads consists of a drastic replacement of the agricultural system that prevailed in the Seine basin; that is, replacing a conventional intensive cropping system with a generalized organic one. Based on a large experimental field study on leaching using suction cups, a 30\% reduction of nitrogen leaks to the unsaturated zone, then to the aquifer, was found using organic farming (Benoit et al., 2014 , 2016). A $30 \%$ decrease was also found in $\mathrm{N}_{2} \mathrm{O}$ emissions (Benoit et al., 2015). Calculating the $\mathrm{N}$ balance of farm soils (total $\mathrm{N}$ inputs to soils - export from harvest) also made it possible to estimate losses to aquifers, considering that $70 \%$ of the $\mathrm{N}$ balance was leached during the winter drainage period in arable soils (Anglade et al., 2015). Comparing the soil nitrogen balance of farms with experimental measurements of $\mathrm{N}$ leaching in a variety of farms with their specific practices allowed us to modulate the amount of their losses; for example, a reduction when soils were covered with nitrogencatching crops (Anglade et al., 2017). Organic cropping can, therefore, be an efficient alternative agricultural system to the conventional system in terms of environmental nitrogen (nitrate and $\mathrm{N}_{2} \mathrm{O}$ ) contamination. In addition, the use of pesticides is completely banned, which also argues in favor of organic farming. In addition to the environmental performance of organic farming, its agronomical performance has been demonstrated, with organic and conventional farming showing a similar yield versus $\mathrm{N}$ input relationship (Anglade et al., 2015).

With such robust knowledge on organic farming in the Seine basin, a realistic scenario of a deep structural agricultural change, organic, local, and demitarian has 
been elaborated at the scale of the Seine basin and compared with a mandatory scenario advocating good agricultural practices. These two agricultural scenarios are compared to the reference situation (average for the 2002-14 period) and the application of the EU directive for urban wastewaters (WWUD), conditions that are included in the two agricultural situations (Fig. 5.2.18).

The organic-local and demitarian scenario is based on organic diversified rotations without use of mineral fertilizers, with a reconnection of livestock and crop farming, using the local forage following the specification for organic cattle breeding and a human diet based on half the current animal protein ration substituted by vegetal proteins (Billen et al., 2014; Garnier et al., 2016; Billen et al., 2018b; Garnier et al. 2018a,b). Good agricultural practices follow current regulations. For example, farmers have to limit the soil $\mathrm{N}$ balance below a value
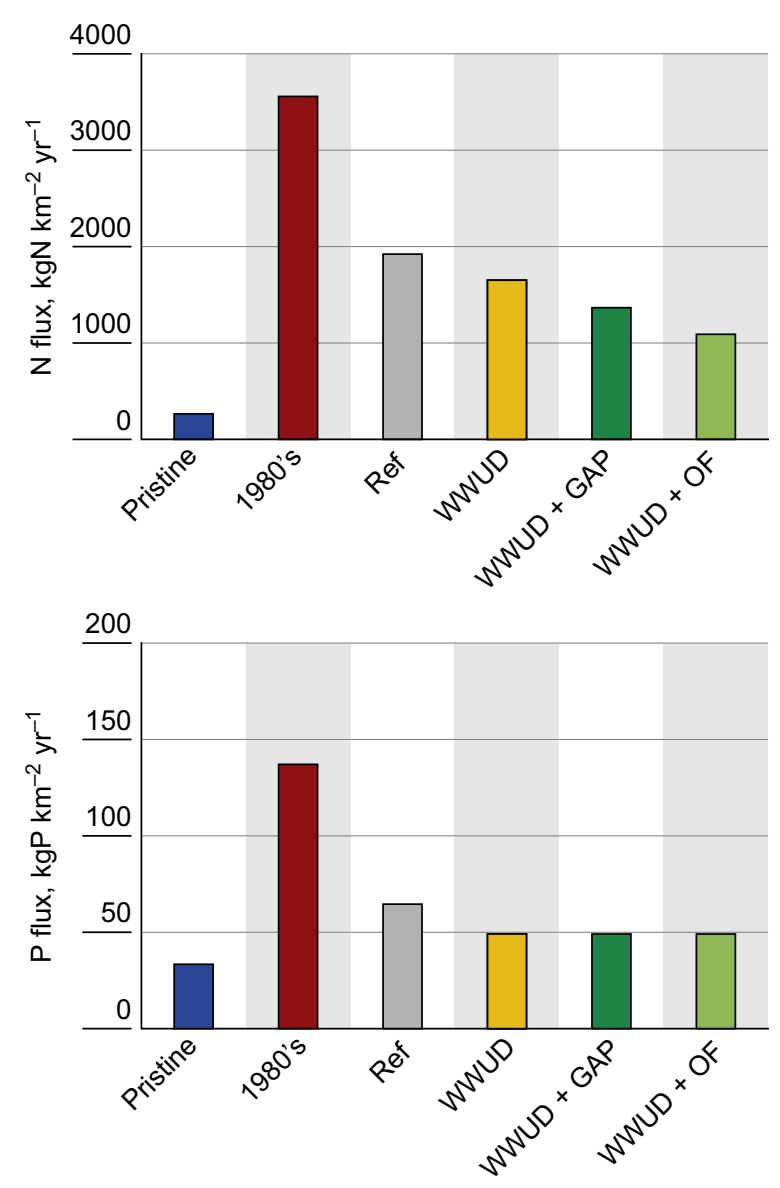

FIGURE 5.2.18 Scenarios of $\mathrm{N}$ and $\mathrm{P}$ management on the whole Seine basin (simulated specific exports of $\mathrm{N}$ and $\mathrm{P}$ in $\mathrm{kg} / \mathrm{km}^{2} / \mathrm{yr}$ at the outlet). Scenarios include: pristine-no human impact; $1980 \mathrm{~s}-$ conditions before wastewater treatment improvement; Reference-2002-14 period; WWUD-full implementation of the EU wastewater urban directive; WWUD + Good Agr. Practice - + Current agricultural regulations; WWUD+ Org. F -+ Organic farming including local feed supply and a demitarien diet, that is, a reduction of $50 \%$ of animal product in the diet. of $50 \mathrm{~kg} \mathrm{~N} / \mathrm{ha} / \mathrm{yr}$ in areas vulnerable to nitrate contamination and to strictly optimize nitrogen and phosphorus fertilization by following provisional calculations formulas established by COMIFER (www. comifer.asso.fr/). In addition, two extreme situations are provided, a pristine condition without human activity over the Seine basin (typically forested basins), and a back to the 1980s condition, which shows the resulting $\mathrm{N}, \mathrm{P}$ fluxes as they were before implementation of the WWUD, when only standard activated sludge treatment was considered for cities above 2000 inhab. equivalent (Fig. 5.2.18). The results show that water quality has been substantially improved with upgraded treatments in WWTPs (1980 vs. WWUD), but also reveals that these treatments have been mostly achieved given that little difference appeared in terms of phosphorus fluxes between the "Reference scenario" and the "WWUD" scenario (Fig. 5.2.18). Agricultural scenarios, however, further reduced $\mathrm{N}$ fluxes, particularly in the Seine and Eure basins.

Application of these rates to the $\mathrm{N}$ and $\mathrm{P}$ inputs to the English Channel does not significantly reduce diatom biomass, while maximum harmful algal blooms (HAB, mostly dinoflagellates) are considerably reduced, pointing out the need for agricultural measures in the Seine basin for reducing coastal eutrophication (Passy et al., 2016).

\subsubsection{Human impact, conservation, and management}

\subsubsection{The 1964 Water Law: a turning point in river management}

Before 1964, river management was not coordinated at the basin level: smaller non-navigated rivers were managed at the local scale while larger and navigated reaches were managed by the French national government, including water policy. Paris, the capital city, was the dominating power in the Seine basin, with its own water institutions (water supply, water treatment) created at the end of the 19th century (Barles and Guillerme, 2014; Lestel and Carré, 2017). From 1964 to 2000 , there was an acceleration in the construction of regulatory water quality (see Section 5.2.8.4) followed by its implementation (Bouleau et al., 2017). The 1964 water law, the starting point of river management in France, added the basin level to previous levels and, in 1968, established the Seine-Normandie river basin authority (AFBSN, today AESN) to collect taxes on point sources of pollution and water withdrawal, fund WWTPs and start (in 1971) water quality monitoring and assessment, still in place today. Other key public basin institutions were also created, such as the Seine 
reservoirs institution in 1969 (IIBRBS, now Seine Grands Lacs), for water storage and river regime control, and the sewage treatment institution for Paris and its suburbs in 1971 (SIAAP).

In 1992, another law recognized water and water bodies as a common patrimony of the nation, and in 2004 a new law was accepted (no. 2004-338 of April 21, 2004), corresponding to the transposition of the EUWFD passed in 2000. Other European directives have played a key role in French river basin management such as the EEC urban wastewaters directive (EEC 91/ 271), which boosted the treatment of nitrogen and phosphorus in WWTPs, and the 1991 nitrate directive. The OSPAR convention also forced French authorities to reduce pollutant fluxes to the Atlantic Ocean. All have been gradually applied, with a 5-10 year lag, in the Seine basin (Lestel and Carré, 2017).

In addition to this stepwise regulatory water quality construction, one must recognize that the present morphological state of the river network, from headwaters to the estuary, largely depends on former river habitat modifications in response to societal needs and water uses, without much consideration for the ecological status of water bodies. This has resulted in what is today considered a general physical alteration of the river network that has evolved over time: (1) construction of canalized reaches with sluices and island removal (1850-1920 then 1960-1970s), allowing river stage regulation in navigated reaches, (2) construction of regulation and storage reservoirs (1931-1949; 1966-1990), (3) loss of first-order streams (after 1960) and wetland drainage on plateaus (1856-1980s), (4) conversion of thousands of ponds into cropland, (5) river bank artificialization within Paris, and (6) estuarine wetland destruction and navigation channel dredging. The Seine River within and downstream of Paris (250$\mathrm{km}$ reach) and many rivers in Paris' suburban area are classified within the WFD as highly modified water bodies that cannot meet the good ecological state target, but a permanent modification of the network is much greater. Today, navigation is still a major river activity, managed by two specific organizations (a national administration, the Voies Navigables de France-VNF, and Haropa, an economic alliance of the ports of Le Havre, Rouen and Paris) managing a linear reach of $500 \mathrm{~km}$ of waterways and organizing the transport of goods between the rich cereal hinterland of the Paris basin to its estuary.

The next key use is drinking water supply, $60 \%$ of which is provided by groundwater. Surface water is used mainly to supply the Paris agglomeration and population living in the Morvan region. The Seine still contributes to industry, mainly for cooling. Emerging uses are irrigation, which increased by a factor of three between 1970 - 2000, particularly with groundwater in the central part of the basin (the Beauce region), and river recreation, which developed following the restoration of basic water quality over the last $10-20$ years. The uses of the Seine River within the Paris region are very peculiar: commercial river traffic coexists with industrial uses and recreational activities. Amateur fishing, although increasing in the Parisian sector, is mainly practiced on other rivers, in dedicated ponds, and in headwaters.

\subsubsection{Flood control and river regime modification}

Floods of the Seine River result from long and/or intense periods of rainfall. The 1910 historical flood, when part of Paris was underwater, limiting urban activity for two months, resulted in the construction of a first set of medium-sized storage reservoirs in the 1930s-1940s, totaling $\sim 130 \mathrm{Mm}^{3}$ capacity in the Morvan mountains, the upper part of the Yonne River (e.g., Pannecières reservoir, see Fig. 5.2.1). A second set of three large reservoirs $\left(750 \mathrm{Mm}^{3}\right)$ was constructed in the central part of the basin, bypassing the Seine, Marne, and Aube rivers (see Fig. 5.2.1), with multiple objectives for water use, to: (1) control medium floods, (2) sustain summer low flows for navigation and improve the water quality downstream of Paris, (3) provide cooling water to the Nogent nuclear power plant upstream of Paris, and (4) provide irrigation water. Flood control has a limited efficiency when extreme intense rainfall events occur, as in May-June 2016 on a $5000-\mathrm{km}^{2}$ region between SE Paris and the SeineYonne confluence, then again in winter 2018: part of Paris suburbs and Paris river banks were inundated for two weeks. Artificial storage facilities in the Bassée, the major wetland area of the Upper Seine, are now envisaged. All the construction done on the Seine has greatly modified the low-flow regime: typical low flows in Paris have increased from 40 to $100 \mathrm{~m}^{3} / \mathrm{s}$ since the beginning of the 20th century, thus increasing the dilution power of the river, which receives about $30 \mathrm{~m}^{3} / \mathrm{s}$ of treated wastewaters from Paris and an estimated $15 \mathrm{~m}^{3} / \mathrm{s}$ from the remaining basin.

\subsubsection{Water quality management and the wastewater treatment}

Paris' wastewater management scheme was inherited from the Second Empire (1852-70) when sewage farms were used to partially treat the collected 
effluents of $2 \mathrm{M}$ Parisians, a treatment method that lasted until the 1970s. As the city was expanding to nearby villages and agricultural lands, from 1870 (1.85 M inhabitants, $75 \mathrm{~km}^{2}$ urban area) until today's megacity $\left(10.3 \mathrm{M}\right.$ inhab. within $\left.2845 \mathrm{~km}^{2}\right)$, urban growth gradually affected nearby streams, eventually converted into open sewers, then covered in the early 1900s (e.g., Croult, Bièvre). Today, these suburban rivers surrounding Paris are being restored and there is citizen demand to reopen their covered reaches (Carré et al., 2011). Therefore renaturalization engineering works have been in progress for the last 10 years. However, it is unlikely they will ever recover their original state, as river habitats have been permanently modified (see Section 5.2.6.5).

Until the 1950s in medium-sized cities and towns, individual sanitation prevailed but then wastewater collection was installed. At that time, the collected sewage was released without treatment into rivers, particularly those having adequate dilution power: the general rule was that river discharge should exceed sewage discharge by a factor of 10 . This management had severe limits: (1) it did not take into account the decreased dilution power at low flows, (2) it overestimated the self-purification capacity of rivers for organic pollution when untreated effluents were cumulated, and (3) it did not take into account other water quality issues than organic pollution, such as heavy metals and PAHs. This collection-treatment lag generated a generalized and severe degradation of water quality downstream of Paris and other cities within the Seine basin (e.g., Vesle River at Reims).

In 1964, the Water Law established a public financing system. As a result, the WWTP network was gradually developed in 25 years to cover the whole basin. Paris was a priority and the Achères WWTP downstream of Paris, now called Seine-Aval and managed by the SIAAP, was developed to treat up to $8 \mathrm{M}$ inhabitants at its maximum capacity (today $6 \mathrm{M}$ inhabitants). Later, other WWTPs were developed to treat wastewaters of the Parisian agglomeration and the capacity of SeineAval was decreased to $6 \mathrm{M}$ people. The gap between the rate of sewage collection and treatment was only closed in the 1990s-2000s for the first type of water quality degradation, organic pollution, and its indicatorsdissolved oxygen, BOD5, COD, and ammonia-were improved. Downstream of Paris, the dissolved oxygen concentration of the Seine, measured since the 1880s, showed a long period of severe summer hypoxia until its restoration in the mid-1990s (Meybeck et al., 2018). During this period, the population of cities along the lower Seine had to shift from their usual river water supply to groundwater supply, as for Versailles (Dmitrieva et al., 2018).
The collection and treatment of organic pollution within Paris (1970s-1990s) has been complemented in the last 20 years in two directions: (1) the treatment of nutrients, phosphorus first, then the nitrification of ammonia and finally the denitrification at the main WWTP, Seine-Aval (see Sections 5.2.6.2, 5.2.7.1, and 5.2.7.2), and (2) the improvement of the Seine water quality within its Parisian sector, during rain events (see also Section 5.2.5.2). Before the late 1990s, overflows of combined sewers into the Seine without treatment ranged between 45 and $145 \mathrm{Mm}^{3}$ per year. These events, mostly observed in summer, generated sudden oxygen depletions in the river for a few hours, sometimes resulting in massive fish kills, the ultimate water quality indicator. To alleviate this impact, in 1996, the SIAAP installed "fish survival islands" in the river where the air was directly injected downstream of the main overflow site. Between 2002 and 2004, these CSO waters were greatly reduced by a factor of 10 by underground storage in large dedicated facilities before being released to WWTPs. The overall storage capacity was $0.9 \mathrm{Mm}^{3}$ in 2010 and is planned to reach $1.5 \mathrm{Mm}^{3}$ in 2020 . This puts an end to the structural flaw of the sewage management created in the 1870s. Today, untreated CSO waters account for only $2 \%$ of the total volume of sewage water managed by the SIAAP. The detailed history of the Paris sewer system is found in Barles and Guillerme (2014) and Rocher and Azimi (2017).

\subsubsection{Assessing, reporting and declaring river water quality: a social construction}

The perception and selection of water quality issues, their relevant indicators, the establishment of reference levels and water quality scales, and monitoring strategies depend on the development of scientific knowledge, societal concern and arbitration between actors of water quality, technical innovations, regulations, and dedicated funds. These multiple interactions are gradually constructed by societies at a given stage of their relationship with a river (Bouleau et al., 2017; Carré et al., 2017a; Meybeck and Lestel, 2017; Meybeck et al., 2018). The establishment and official declaration of water quality by relevant authorities started in the Seine basin in the 1970s. At that time, there was little academic knowledge or curricula dedicated to river quality, nor specialized laboratories, monitoring or assessment manuals. Many water quality problems at that time were demonstrated decades later.

The conversion of measured or modeled concentrations of chemical indicators into water quality assessment and its translation into color-coded water quality classes is now a standard procedure for general reporting as required by the WFD. In addition, processing of 
the yearly water quality data, which have been multiplied by three orders of magnitude in 50 years, is now fully automatized. Several issues remain however: (1) it does not take into account the multiple uncertainties, biases, and flaws of monitoring (e.g., fine-scale temporal variations are not seen by conventional monthly frequency, resulting in uncertainties), (2) the declared water quality depends on the number of parameters considered, and (3) on aggregations and conversion rules. For example, the WFD requires considering always the worst quality of a given indicator, not the median, and a single indicator may degrade the overall quality set by all others (Carré et al., 2017b).

Fig. 5.2.19 illustrates some of the assessment and reporting issues for the declared water quality in the 250-km-long lower Seine (Vilmin et al., 2018). Concentrations of six basic water quality indicators of the WFD have been simulated over 6 years at high frequency $(<1 \mathrm{~h})$ using the PROSE model, then converted into color-coded quality, as advised by the WFD. Downstream of the Paris WWTPs (km 50), measured quality, using WFD criteria, depends on the chemical indicator and river regime (summer low water vs. winter high water). The overall regulatory quality ("total") determined by the worst indicator is downgraded to poor or bad on the basis of only one indicator, nitrite. This does not reflect the reality of the $200-\mathrm{km}$ impacted river sector, as the overall quality (temporal $\times$ spatial $\times$ indicator) is nevertheless one or two quality classes better. The message conveyed to local water users and basin decision-makers, as required by the WFD, could be much different from another set of rules, for example, using the former SEQ-Eau national water quality scale.

\subsubsection{Trajectories of river quality issues in the Seine River basin}

Each subbasin, even each river monitoring station, has its own trajectory for a given water quality issue. Multiple examples of improving trends have been given, particularly for the lower Seine, as shown in previous sections. They are mostly related to the reduction of

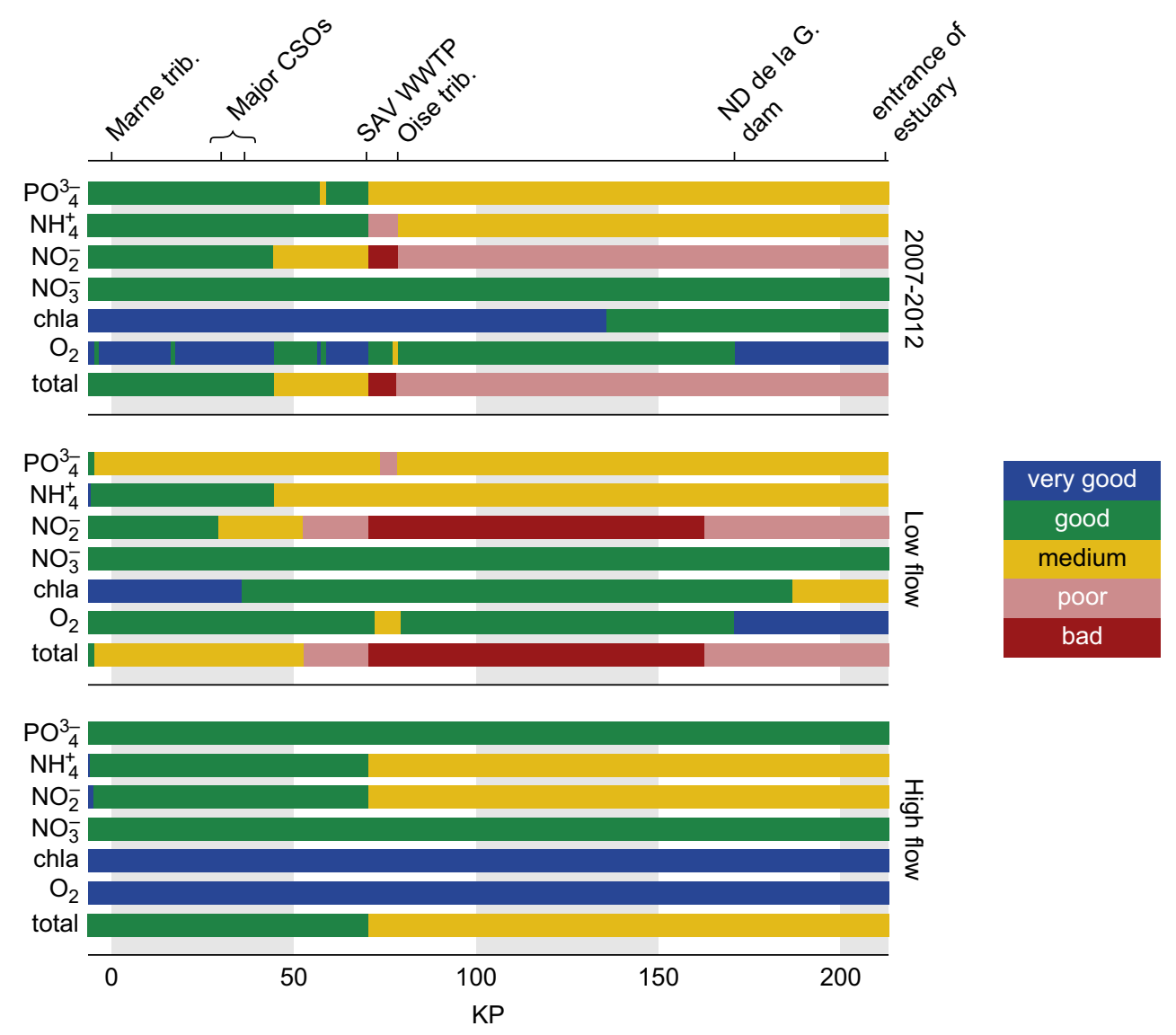

FIGURE 5.2.19 Variability and complexity of water quality assessments derived from data treatments. Average quality profiles over the 250$\mathrm{km}$ lower Seine (2007-12). Yearly quality for low flow and high flow. Database used: simulated continuous concentrations of six basic chemical indicators derived from the PROSE model (Total = overall water quality for the six basic water quality indicators, using EU-WFD rules). Water quality scale and color code of the WFD (Vilmin et al., 2018). Marne trib.: Marne/Seine confluence (see Fig. 5.2.1); Major CSOs, combined sewers overflow in Paris center; SAV-WWTP, Seine-Aval wastewater treatment plant; ND de la G. dam, Notre-Dame-de- la-Garenne dam, $40 \mathrm{~km}$ upstream Poses (see Fig. 5.2.1); KP, kilometric points from Paris center. 
urban point sources, which first concerned organic matter (BOD and COD) and suspended particulate matter and their attached bacteria and pollutants (heavy metals, PCBs, PAHs).

Then the treatment of urban sources of phosphorus, responsible for a high eutrophication level in stream orders above 4, was progressively implemented in 1999 for the Seine-Aval facility, resulting in a marked decrease of summer chlorophyll. Finally, nitrogen treatment in WWTPs was implemented in two steps, in 2007 and 2011 for the Seine-Aval plant. This improvement was observed on other urban-impacted rivers such as the Vesle River, downstream of Reims, and Parisian rivers such as the Orge. Ammonia pollution, once prevalent in all Paris suburban rivers, has now been considerably decreased, sometimes by two orders of magnitude, and ammonia inputs to the North Sea have been reduced, meeting the OSPAR target.

For each river sector, trajectories of each water quality issue can be determined. Before 1971, only organic pollution and parallel fecal contamination were monitored. Nitrate and eutrophication were not perceived as major issues before the mid-1980s. In the same line, before the 1990s the severity of metal contamination was not perceived and its trend was unveiled much later, based on sediment archives. Regarding nitrogen, nitrate concentration has just recently started to level off at the outlet of the river (see Figs. 5.2.16 and 5.2.17).

Authority responses to water quality issues are quite variable. They were insufficient (from the 1880s to 1990s) for organic pollution, show important lags for phosphorus and more for nitrogen (e.g., 20 years for river eutrophication $[\mathrm{P}]$, more for coastal eutrophication [N]). They were simply untargeted for metal as decontamination started in the 1960s, caused by industrial process modifications, long before any regulation. In the last 15 years, the reduction in overflows of combined sewers, an issue that dated from the 1870s, improved the oxygen level of the Seine at Paris. Other water quality questions are not yet efficiently addressed: the societal response to pesticide contamination looks like the barrel of the Danaids; as soon as one substance is regulated or banned, it is replaced by a new one.

\subsubsection{Conservation and restoration measures in aquatic ecosystems}

To achieve the good ecological status of water bodies required by the WFD, it is necessary both to preserve freshwaters from alterations and to restore water bodies that have already been degraded. This is the objective of the Water Development and Management Master Plan (SDAGE) for the Seine basin. Other former European directives, such as the Habitats or Birds directives, also have protection objectives, which may improve aquatic ecosystems.

\subsection{Protection of aquatic habitats}

In the Seine basin, several water bodies have been classified as "Natura 2000" sites in running waters or wetlands: certain valleys (Petit Morin in the east, Epte, and the Seine meanders in the west) and large reservoirs ("Forêt d'Orient lake" and "Der lake", RS and RM, respectively, on Fig. 5.2.1). These sites are notably important areas for waterfowl but also correspond to particular functional conditions of aquatic ecosystems. A part of the Seine River floodplain, La Bassée, constitutes a national natural reserve that includes smaller but exceptional Natura 2000 sites for wetlands and alluvial forests. Downstream of the Seine River, there are two other national natural reserves, the Seine estuary and the Vernier marshland. The proposed construction of shallow water storage facilities in the Bassée for flood protection may jeopardize such natural reserves.

\subsection{Restoration of habitats and ecological continuity}

In the Seine basin, streams are currently impacted by the presence of around 5000 hydraulic structures (small dams or weirs, without considering locks). Their overall density is one every $12 \mathrm{~km}$ of reach, but in downstream tributaries of the Seine River, this density is higher, one every $2-3 \mathrm{~km}$. The current program of the Seine River basin authority (2016-2021) enhances the following objectives: morphological restoration of $760 \mathrm{~km}$ of streams and removal of 800 dams per year (or equipping them with fish passes to restore ecological continuity). These measures can globally contribute to restore the original biodiversity and establishing green and blue infrastructures along stream corridors. Modeling fish habitat connectivity in streams would allow prioritizing restoration actions to improve ecological continuity at the basin scale (Roy and Le Pichon, 2017). A real comprehensive restoration program has not yet been established at the basin scale, which requires a hierarchical framework of pressures, followed by restoration planning to manage these pressures.

\subsection{Migratory fish}

In the mid-19th century, before the major canalization scheme, diadromous fish fauna comprised 11 species. Currently, seven migratory fish species regularly occur in the lower Seine: six are vulnerable and one, the eel, is critically endangered. The status of these species is monitored by a basin management plan ("Plagepomi"). Moreover, the eel has been part of a European plan since 2010. As these species use both marine and freshwaters, supporting measures for a full recovery concern their whole migration axis. Recently, salmon and shad 
(A)

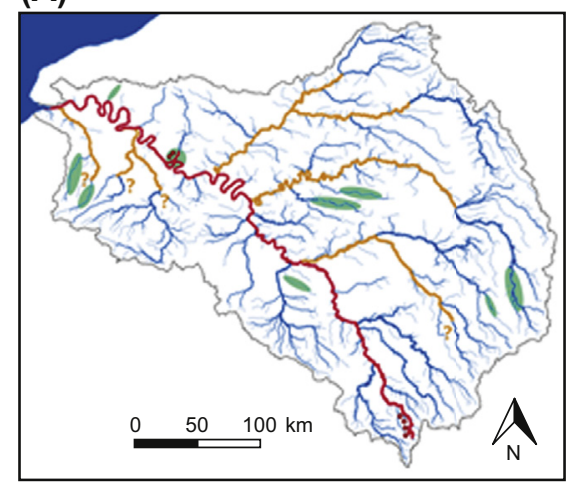

(B)

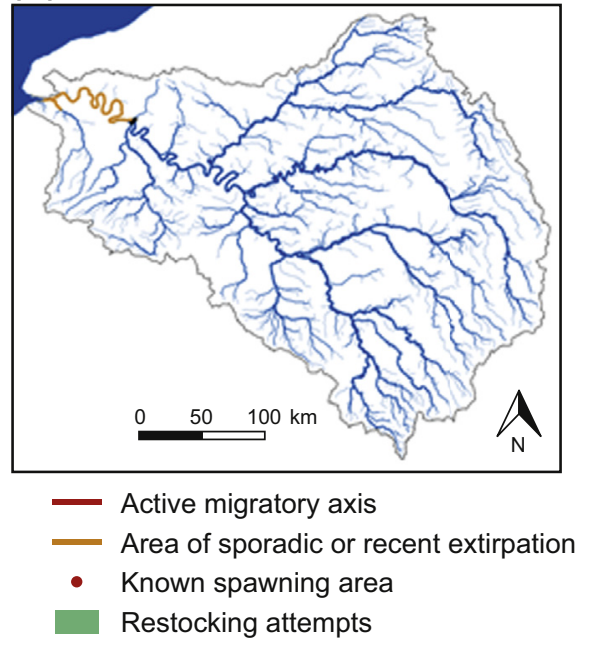

(C)

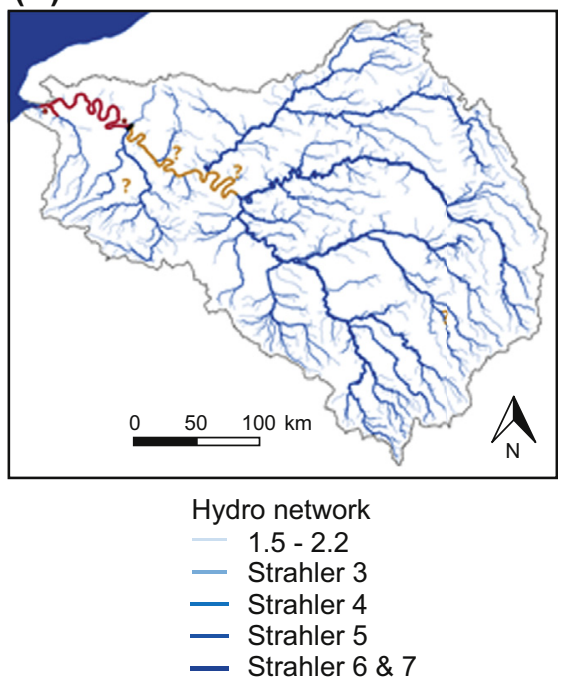

FIGURE 5.2.20 Partial restoration of salmon distribution in the Seine River basin after its complete loss in the Seine basin during the 20th century. (A) Second half of the 19th century, (B) 1970s, (C) Current (2010s).

naturally recolonized the lower Seine, in the absence of restocking programs (Perrier et al., 2010; Belliard et al., 2009b; Fig. 5.2.20). For salmon, fish individuals originate from nearby populations outside the Seine basin. These returns result from the progressive installation of navigation dams with fish passes, combined with the improvement in water quality since the 1990s. Restoration actions are still necessary to observe real self-sustaining populations of salmon and shad in the Seine.

In this domain of conservation and restoration of the Seine River, it is necessary to move to a more integrative approach, taking into account the current multipressure context and long-term legacies (channelization, impoundment, pollution).

\subsubsection{Conclusions and lessons learnt}

The Seine basin is a rare documented example of the gradual deterioration - followed by a partial recoveryof a river facing multiple fast-growing pressures and water uses over 150 years; that is, long before the first regulatory monitoring of river quality in the 1970s. First, it is a good model to study how the impact of an extreme pressure/river ratio $\left(2.10^{5}\right.$ people per $\mathrm{m}^{3} / \mathrm{s}$ at the low stage) has been handled over time, such as bridging the wastewater treatment gap only after 130 years. Second, the Seine River scientists have developed a new domain of river science through global biogeochemical modeling, integrating from hydroclimatic models to socio-economic models (e.g., urban sanitation, agriculture, consumer practices) distributed at fine resolution from headwater streams to the estuary.
Modeling the river basin, its physical and ecological network, and its various economic and social activities has shown that these components, generally treated separately, can and should be considered as a single entity. The biogeochemical functioning of the Seine basin was analyzed, featuring the circulation of carbon and nutrients from headwaters to the estuary and its related water quality at different spatial and temporal scales. For example, coastal algal blooms are linked to previous decades of agricultural practices on headwaters. A model toolbox has been used, in combination with the future river regime based on climate change scenarios, population scenarios and water needs scenarios, to explore the future of the Seine basin concerning water uses, agricultural changes, impacts of new water reservoirs and WWTP modifications. Other models are used to estimate the WFD water quality for unmonitored waterbodies or simulate the continuous water quality between two measurements.

Specific attention was gradually given to the long term through (1) backward reconstruction of water quality, using pressure-state models, (2) reconstruction of historical archives of water quality since the 1880s, (3) reconstruction of past contaminations from sedimentary archives, (4) construction of a unique and still-growing set of data concerning the river and its internal and external control factors (climate and hydrology, land use, population, wastewater treatment, aquifers, urbanization and industrialization, material flow, water quality, river habitat, fish population) at a fine resolution and over 50-150 years, and (5) the study of river institutions and water regulations over the last 150 years, at least.

During the last 60 years, the Seine River basin has undergone profound changes (industrial decline, 
agriculture intensification, canalization, urban growth). Meanwhile, some water uses required excellent water quality. This contradiction has been gradually resolved by the continuous development of treatment plants and the application of ever more stringent environmental regulations, now prescribed at the European level. The evergrowing environmental concern (e.g., for emerging pollutants) has facilitated the taxation of point sources of pollution, essentially from industries and cities, such as Paris, which mainly impacts the lower Seine and the suburban rivers surrounding Paris. The intensive and specialized agriculture that was mostly developed within the basin after 1960 is the other major control factor on the river network quality, its multiple impacts (e.g., in terms of nitrate and pesticides) which are not yet reduced. This chapter shows that the Seine basin is now controlled by external factors such as imports, EU regulations, and global economics. The input-output balances of materials (metals, phosphorus, nitrogen, many chemicals) show that the circulation of these materials in the anthroposphere is much larger than river fluxes generated by natural processes (e.g., erosion, weathering, carbon uptake, $\mathrm{N}$ fixation). River chemistry is highly dependent on the leakage rates of these circulations, which may vary over two orders of magnitude $(0.1 \%-10 \%)$.

The water quality of many parameters is today largely controlled by basin managers. In general, good status is the target; that is, management aims at the yellow-green transition, meaning that the excellent or blue status (pristine conditions of geochemists) is likely to disappear in such a basin. Major changes in aquatic biota also are expected, such as for introduced and/or invasive fish species. Finally, many large structures (dams and discharge-regulation reservoirs, navigated reaches with locks) have a permanent status. In other terms, the Seine River and its basin are under typical Anthropocene conditions (Meybeck and Lestel, 2017). Considering the exponential growth and complexity of scientific knowledge, institutions and regulations, especially related to water quality, large structured cooperative projects are needed. The interdisciplinary PIREN-Seine program, thanks to its constant linkage with basin institutions over 30 years, has been at the forefront to explore this new domain, unveil basinsociety interactions and contribute adequate tools to water managers for basin restoration through (1) development of an intertwined community of scientists, from various disciplines, and managers, from all basin institutions, some of the latter initially trained within the program, (2) emergence of shared concepts, and (3) construction of interconnected models, databases, and management tools-the PIREN-Seine cascade modelthat operate at different temporal and spatial scales.

\section{References}

Aissa Grouz, N., Garnier, J., Billen, G., Mercier, B., Martinez, A., 2015. The response of river nitrification to changes in wastewater treatment (The case of the lower Seine River downstream from Paris). Annales de Limnologie - International Journal of Limnology 51, 351-364. https: / /doi.org/10.1051/limn/2015031.

Aissa Grouz, N., Garnier, J., Billen, G., 2018. Long trend reduction of phosphorus wastewater loading in the Seine: determination of phosphorus speciation and sorption for modeling algal growth. Environmental Science and Pollution Research 25, 23515. https:/ / doi.org/10.1007/s11356-016-7555-7.

Akopian, M., 1999. Cinétique et rôle du Zooplancton dans les flux de matière particulaire: du lac de Der-Chantecoq (réservoir de la Marne) à l'estuaire de la Seine. Thèse Univ. P\&M. Curie, 208 pp.

Akopian, M., Garnier, J., Testard, P., Ficht, A., 2001. Impact of the colonization of Zebra Mussel (Dreissena polymorpha) in the Seine River. Estimating the benthic communities from the larvae fluxes. Estuaries 24, 1003-1014.

Akopian, M., Garnier, J., Pourriot, R., 2002. Zooplankton in an aquatic continuum: from the river Marne and its reservoir to the Seine estuary. Comptes Rendus de l'Académie des Sciences 325, 807-818.

Anglade, J., Billen, G., Garnier, J., Makridis, T., Puech, T., Tittel, C., 2015. Agro-environmental performance of organic compared to conventional cash crop farming in the Seine watershed. Agricultural Systems 139, 82-92.

Anglade, J., Billen, G., Garnier, J., 2017. Reconquérir la qualité de l'eau en régions de grande culture : agriculture biologique et reconnexion avec l'élevage. Fourrages 231, 257-268. www.afpf-asso.org.

Arnold, J.G., Allen, P.M., 1999. Automated methods for estimating baseflow and ground water recharge from streamflow records. Journal of the American Water Resources Association 35, 411-424. https://doi.org/10.1111/j.1752-1688.1999.tb03599.x.

Ayrault, S., Rianti, C., Evrard, O., Lefèvre, I., Bonté, P., 2010. Silver and thallium historical trends in the Seine River basin. Journal of Environmental Monitoring 12, 2177-2185. https://doi.org/10.1039/ COEM00153H.

Ayrault, S., Roy-Barman, M., Le Cloarec, M.-F., Priadi, C., Bonté, P., Göpel, C., 2012. Lead contamination of the Seine River, France: geochemical implications of a historical perspective. Chemosphere 97, 902-910.

Ayrault, S., Priadi, C.R., Le Pape, P., Bonté, P., 2013. Occurrence, sources and pathways of antimony and silver in an urban catchment. In: Rauch, Morrison (Eds.), Urban Environment. Springer, pp. 425-435.

Ayrault, S., Le Pape, P., Evrard, O., Priadi, C.R., Quantin, C., Bonté, P., Roy-Barman, M., 2014. Remanence of lead pollution in an urban river system: a multi-scale temporal and spatial study in the Seine River basin, France. Environmental Science and Pollution Research 21, 4134-4148.

Azimi, S., Rocher, V., 2016. Influence of the water quality improvement on fish population in the Seine River (Paris, France) over the 19902013 period. The Science of the Total Environment 542, 955-964.

Baratelli, F., Flipo, N., Moatar, F., 2016. Estimation of distributed stream-aquifer exchanges at the regional scale using a distributed model: sensitivity to in-stream water level fluctuations, riverbed elevation and roughness. Journal of Hydrology 542, 686-703.

Barles, S., Guillerme, A., 2014. Paris: a history of water, sewers and urban development. In: Tvedt, T., Oestigaard, T. (Eds.), A History of Water, Series III, vol. 1. I.B. Taurus, pp. 384-409.

Belliard, J., Gorges, G., Le Pichon, C., Tales, E., 2009a. Le peuplement de poissons du bassin de la Seine. Comprendre son évolution sous l'impact des changements générés par l'homme ou la nature. Agence de l'eau Seine-Normandie, Paris, 43pp. 
Belliard, J., Marchal, J., Ditche, J.M., Tales, E., Sabatie, R., Bagliniere, J.L., 2009b. Return of adult anadromous allis shad (Alosa alosa L.) in the River Seine, France: a sign of river ecovery? River Research and Applications 25, 788-794.

Belliard, J., Beslagic, S., Delaigue, O., Tales, E., 2018. Reconstructing long-term trajectories of fish assemblages using historical data: the Seine River basin (France) during the last two centuries. Environmental Science and Pollution Research 25, 23430. https:// doi.org/10.1007/s11356-016-7095.

Benoit, M., Garnier, J., Anglade, J., Billen, G., 2014. Nitrate leaching from organic and conventional arable crop farms in the Seine Basin (France). Nutrient Cycling in Agrosystems. https://doi.org/ 10.1007/s10705-014-9650-9.

Benoit, M., Garnier, J., Billen, G., 2015. Nitrous oxide production from nitrification and denitrification in agricultural soils: determination of temperature relationships in batch experiments. Biochemical process 50, 79-85. https://doi.org/10.1016/j.procbio.2014.10.013.

Benoit, M., Garnier, J., Beaudoin, N., Billen, G., 2016. A network of organic and conventional crop farms in the Seine Basin (France) for evaluating environmental performance: yield and nitrate leaching. Agricultural Systems 148, 105-113.

Billen, G., 1991. Protein degradation in aquatic environments. In: Chrost, R. (Ed.), Microbial Enzyme in Aquatic Environments. Springer Verlag, Berlin, pp. 123-143.

Billen, G., Cavelier, C., Dessery, S., Lancelot, C., Meybeck, M., Somville, M., 1984. Evolution de la qualité de la rivière Oise lors de sa rétention dans le bassin de storage de Méry. Verhandlungen des Internationalen Verein Limnologie 22, 1510-1515.

Billen, G., Garnier, J., Hanset, P., 1994. Modelling phytoplankton development in whole drainage networks: the RIVERSTRAHLER model applied to the Seine river system. Hydrobiologia 289, 119-137.

Billen, G., Garnier, J., 1997. The Phison River Plume: coastal eutrophication in response to changes in land use and water management in the watershed. Aquatic Microbial Ecology 13, 3-17.

Billen, G., Garnier, J., Meybeck, M., 1998. Les sels nutritifs: l'ouverture des cycles. In: Meybeck, M., De Marsily, G., Fustec, F. (Eds.), La Seine en son bassin Fonctionnement écologique d'un système fluvial anthropisé. Elsevier, Paris, pp. 531-565. Chapitre 12.

Billen, G., Garnier, J., 2000. Nitrogen transfers through the Seine drainage network: a budget based on the application of the Riverstrahler model. Hydrobiologia 410, 139-150.

Billen, G., Garnier, J., Ficht, A., Cun, C., 2001. Modelling the response of water quality in the Seine Estuary to human activity in its watershed over the last 50 years. Estuaries 24, 977-993.

Billen, G., Garnier, J., 2007. River basin nutrient delivery to the coastal sea: assessing its potential to sustain new production of non siliceous algae. Marine Chemistry 106, 148-160. https://doi.org/ 10.1016/j.marchem.2006.12.017.

Billen, G., Garnier, J., Némery, J., Sebilo, M., Sferratore, A., Barles, S., Benoit, P., Benoit, M., 2007. Nutrient transfers through the Seine river continuum: mechanisms and long term trends. The Science of the Total Environment 375, 80-97. https://doi.org/10.1016/ j.scitotenv.2006.12.005.

Billen, G., Silvestre, M., Grizzetti, B., Leip, A., Bouraoui, F., Behrendt, H., Garnier, J., Lepisto, A., Kortelainen, P., Johnes, P., Curtis, C., Humborg, C., Smedberg, E., Kaste, O., Ganeshram, R., Beusen, A., Voss, M., Lancelot, C., 2011. Nitrogen and Regional Watersheds in Europe (including Coastal and Marine issues, 271-297. Part III - nitrogen flows and fate at multiples special scales. Chapter 13. In: Sutton, et al. (Eds.), European Nitrogen Assessment. Cambridge University Press, London, 612pp.

Billen, G., Garnier, J., Lassaletta, L., 2013. Modelling the nitrogen cascade from watershed soils to the sea: from regional to global scales. Philosophical Transactions of the Royal Society B 368. https:/ / doi.org/10.1098/rstb.2013.0123, 20130123.
Billen, G., Lassaletta, L., Garnier, J., 2014. A biogeochemical view of the global agro-food system: nitrogen flows associated with protein production, consumption and trade. Global Food Security 209-219. https: / / doi.org/10.1016/j.gfs.2014.08.003.

Billen, G., Ramarson, A., Thieu, V., Théry, S., Silvestre, M., Pasquier, C., Hénault, C., Garnier, J., 2018a. Nitrate retention at the riverwatershed interface: a new conceptual modeling approach. Biogeochemistry. https: / / doi.org/10.1007/s10533-018-0455-9.

Billen, G., Le Noë, J., Garnier, J., 2018b. Two contrasted future scenarios for the French agro-food system. The Science of the Total Environment 637-638, 695-705. https://doi.org/10.1016/j.scitotenv.2018.05.043.

Blanchard, M., Teil, M.J., Carru, A.M., et al., 1999. Biota contamination by PCBs and trace metals in the freshwater estuary of the River Seine (France). Hydrobiologia 400, 149-154. https://doi.org/ 10.1023/ A:1003715131607.

Blanchoud, H., Farrugia, F., Mouchel, J.M., 2004. Pesticide uses and transfers in urbanised catchments. Chemosphere 55, 905-913.

Blanchoud, H., Guigon, M.E., Farrugia, F., Chevreuil, M., Mouchel, J.M., 2007. Contribution by urban and agricultural pesticide uses to water contamination at the scale of the Marne watershed. The Science of the Total Environment 375 (1-3), 168-179.

Boët, P., Belliard, J., Berrebi-dit-Thomas, R., Tales, E., 1999. Multiple human impacts by the City of Paris on fish communities in the Seine river basin, France. Hydrobiologia 410, 59-68.

Bonté, P., Mouchel, J.M., Thomas, A., Le Cloarec, M.F., Dumoulin, J.P., Sogon, S., Tessier, L., 2000. Buffering of suspended sediment transport in lowland river during low water stages: quantification in river Seine using environmental radionuclides. Acta Geologica Hispanica 35, 339-355.

Botta, F., Lavison, G., Couturier, G., Alliot, F., Moreau-Guigon, E., Fauchon, N., Guery, B., Chevreuil, M., Blanchoud, H., 2009. Transfer of glyphosate and its degradate AMPA to surface waters through urban sewerage systems. Chemosphere 77, 133-139.

Bouleau, G., Fernandez, S., 2012. La Seine, le Rhône et la Garonne: trois grands fleuves et trois représentations scientifiques. In: Environnement, discours et pouvoir, pp. 201-218 (Editions Quæ).

Bouleau, G., Marchal, P.L., Meybeck, M., Lestel, L., 2017. La construction politique de la commune mesure de la qualité des eaux superficielles en France : de l'équivalent-habitant au bon état (1959-2013). Développement Durable et Territoires 8 (1). https://doi.org/ 10.4000 /developpementdurable. 11580 .

Brion, N., Billen, G., 1998. Une réévaluation de la méthode d'incorporation de $\mathrm{H} 14 \mathrm{CO} 3-$ pour mesurer la nitrification autotrophe et son application pour estimer des biomasses de bactéries nitrifiantes. Revue des Sciences de l'Eau 11, 283-302.

Brion, N., Billen, G., 2000. Wastewater as a source of nitrifying bacteria in river systems: the case of the river Seine downstream from Paris. Water Research 12, 3213-3221.

Brion, N., Billen, G., Guézennec, L., 2001. Distribution of nitrifying activity in the Seine river (France) from Paris to the estuary. Estuaries 23, 669-682.

Camargo, J.A., Alonso, A., Salamanca, A., 2005. Nitrate toxicity to aquatic animals: a review with new data for freshwater invertebrates. Chemosphere 58, 1255-1267.

Carré, C., De Gouvello, B., Deroubaix, J.F., Deutsch, J.C., Haghe, J.P., 2011. Découvrir les petites rivières d'ile de France. Programme Piren-Seine fasc.11. Agence Eau Seine-Normandie, Nanterre, 85pp.

Carré, C., Lestel, L., Meybeck, M., 2017a. Pour conclure : les trajectoires de qualité des eaux des métropoles européennes. In: Lestel, L., Carré, C. (Eds.), Les rivières urbaines et leur pollution, pp. 268-275. Quae, Paris.

Carré, C., Meybeck, M., Esculier, F., 2017b. The Water framework directive's "percentage of surface water bodies at good status": unveiling the hidden side of a "hyperindicator". Ecological Indicators $78,371-380$. 
Cazier, T., 2015. Rôle des microorganismes dans la dynamique du nitrite dans la Seine. In: Géosciences et Ressources Naturelles. Université Pierre et Marie Curie.

Cébron, A., Coci, M., Garnier, J., Laanbroek, H.J., 2004. DGGE analysis of the ammonia oxidizing bacterial community structure in the lower Seine river: impact of the Paris wastewater effluents. Applied and Environmental Microbiology 70, 6726-6737.

Chevreuil, M., 1978. Evolution et transfert des pesticides, exemple du bassin versant de l'Orgeval Ph D Univ. Pierre et Marie Curie, 73pp.

Chevreuil, M., Blanchard, M., Dargnat, C., et al., 2009. La micropollution organique dans le bassin de la Seine, maîtriser l'impact des molécules créées par 1'homme, 978-2-918251-08-8.

Chevreuil, M., Blanchard, M., Teil, M.J., Chesterikoff, A., 1998. Polychlorobiphenyl behaviour in the water/sediment system of the Seine river, France. Water Research 32, 1204-1212. https:// doi.org/10.1016/S0043-1354(97)00328-5.2.

Chevreuil, M., Chesterikoff, A., Letolle, R., 1987. PCB pollution behavior in The river seine. Water Research 21, 427-434. https:// doi.org/10.1016/0043-1354(87)90190-4.

Cladière, M., Bonhomme, C., Vilmin, L., et al., 2014. Modelling the fate of nonylphenolic compounds in the Seine River - part 1: determination of in-situ attenuation rate constants. The Science of the Total Environment 468, 1050-1058. https://doi.org/10.1016/ j.scitotenv.2013.09.028.

Cladière, M., Gasperi, J., Gilbert, S., et al., 2010. Alkylphenol ethoxylates and bisphenol A in surface water within a heavily urbanized area, such as Paris. In: Marinov, A.M., Brebbia, C.A. (Eds.), Water Pollution 5.2. Wit Press, Southampton, pp. 131-142.

Cladière, M., Gasperi, J., Lorgeoux, C., et al., 2013. Alkylphenolic compounds and bisphenol A contamination within a heavily urbanized area: case study of Paris. In: Environmental Science and Pollution Research International, vol. 20, pp. 2973-2983. https://doi.org/ 10.1007 / s11356-012-1220-6.

COMIFER, 1996. Calcul de la fertilisation azotée. Guide méthodologique pour l'établissement des prescriptions locales Pour les cultures annuelles. Guide actualisé en 2013. https://comifer.asso.fr/index. $\mathrm{php} / \mathrm{fr} /$ publications.html.

Conley, D.J., Kilham, S.S., Theriot, E.C., 1989. Differences in silica content between marine and freshwater diatoms. Limnology and Oceanography 34 (1), 205-213. https://doi.org/10.4319/ 10.1989.34.1.0205.

Curie, F., Gaillard, S., Ducharne, A., Bendjoudi, H., 2007. Geomorphological methods to characterise wetlands at the scale of the Seine watershed. The Science of the Total Environment 375, 59-68.

Dessery, S., Dulac, C., Laurenceau, J.M., Meybeck, M., 1984. Evolution du carbone organique « algal » et « détritique » dans trois rivières du bassin Parisien. Archiv für Hydrobiologie 100, 235-260.

DGS, 2016. Bilan de la qualité de l'eau du robinet du consommateur vis-à-vis des pesticides en 2014, 13pp.

Dmitrieva, T., Lestel, L., Meybeck, M., Barles, S., 2018. Versailles facing the degradation of its water supply from the Seine River: governance, water quality expertise and decision making, 1852-1894. Water History. https: / / doi.org/10.1007/s12685-018-0216-7.

Dris, R., Gasperi, J., Rocher, V., et al., 2015. Microplastic contamination in an urban area: a case study in Greater Paris. Environmental Chemistry 12, 592-599. https://doi.org/10.1071/EN14167.

Dris, R., Gasper, i J., Rocher, V., Tassin, B., 2018. Synthetic and nonsynthetic anthropogenic fibers in a river under the impact of Paris Megacity: sampling methodological aspects and flux estimations. The Science of the Total Environment 618, 157-164. https:// doi.org/10.1016/j.scitotenv.2017.11.009.

Dufayt, O., 2000. Etude expérimentale et modélisation du développement de la Renoncule flottante dans la Semois. Thèse. Fondation Universitaire Luxembourgeoise, Arlon (Belgique).

Eckhardt, K., 2008. A comparison of baseflow indices, which were calculated with seven different baseflow separation methods.
Journal of Hydrology 352 (1-2), 168-173. https://doi.org/ 10.1016/j.jhydrol.2008.01.005.

Edberg, S.C., Rice, E.W., Karlin, R.J., Allen, M.J., 2000. Escherichia coli: the best biological drinking water indicator for public health protection. Journal of Applied Microbiology 88, 106S-116S.

Escoffier, N., Bensoussan, N., Vilmin, L., Flipo, N., Rocher, V., David, A., Métivier, F., Groleau, A., 2018. Estimating ecosystem metabolism from continuous multi-sensor measurements in the Seine River. Environmental Science and Pollution Research 25, 23451-23467.

EU-WFD (Water Framework Directive), 2000. OJ L 327/1 22 (12), 1-72.

Even, S., Poulin, M., Garnier, J., Billen, G., Servais, P., Chesterikoff, A., Coste, M., 1998. River ecosystem modelling: application of the Prose model to the Seine River (France). Hydrobiologia 373, 27-37.

Even, S., Poulin, M., Mouchel, J.-M., Seidl, M., Servais, P., 2004. Modelling oxygen deficits in the Seine river downstream ofcombined sewer overflows. Ecological Modelling 173, 177-196.

Even, S., Bacq, N., Ruelland, D., Billen, G., Garnier, J., Poulin, M., Théry, S., Blanc, S., 2007a. New tools for modelling water quality of hydrosystems: an application in the Seine River basin in the frame of the Water Framework Directive. The Science of the Total Environment 375 (1-3), 274-291.

Even, S., Mouchel, J.-M., Servais, P., Flipo, N., Poulin, M., Blanc, S., Chabanel, M., Paffoni, C., 2007b. Modeling the impacts of Combined Sewer Overflows on the river Seine water quality. The Science of the Total Environment 375 (1-3), 140-151.

Even, S., Thouvenin, B., Bacq, N., Billen, G., Garnier, J., Guezennec, L., Blanc, S., Ficht, A., Hir, P.L., 2007c. An integrated modelling approach to forecast the impact of human pressure in the Seine estuary. Hydrobiologia 588, 13-29.

Flipo, N., Even, S., Poulin, M., Tusseau-Vuillemin, M.H., Améziane, T., Dauta, A., 2004. Biogeochemical modelling at The river scale: plankton and periphyton dynamics - grand Morin case study, France. Ecological Modelling 176, 333-347.

Flipo, N., Even, S., Poulin, M., Ledoux, E., 2005. Hydrological part of CaWaQS (CAtchment WAter Quality Simulator): fitting on a small sedimentary basin. Verhandlungen des Internationalen Verein Limnologie 29, 768-772.

Flipo, N., Even, S., Poulin, M., Théry, S., Ledoux, E., 2007a. Modelling nitrate fluxes at the catchment scale using the integrated tool CaWaQS. The Science of the Total Environment 375, 69-79.

Flipo, N., Rabouille, C., Poulin, M., Even, S., Tusseau-Vuillemin, M.H., Lalande, M., 2007b. Primary production in headwater streams of the Seine basin: the Grand Morin case study. The Science of the Total Environment 375, 98-109.

Flipo, N., Monteil, C., Poulin, M., Fouquet, C., Krimissa, M., 2012. Hybrid fitting of a hydrosystem model: long term insight into the Beauce aquifer functioning (France). Water Resourses Research 48, W05509.

Flipo, N., Mouhri, A., Labarthe, B., Biancamaria, S., Rivière, A., Weill, P., 2014. Continental hydrosystem modelling: the concept of nested stream-aquifer interfaces. Hydrology and Earth System Sciences 18, 3121-3149.

Flipo, N., Labarthe, B., Pryet, A., Baratelli, F., Goblet, P., Akopian, M., 2016. Echanges nappe-rivière à l'échelle du bassin de la Seine, pp. 21-48. PIREN Seine, Interfaces nappe-rivière, Rapport de synthèse 20112015. https://piren-seine.fr/sites/default/files/PIREN_documents / phase_6/rapports_de_synthese/Synthese_Ph6_Vol2.pdf.

Froger, C., Ayrault, S., Evrard, O., Monvoisin, G., Bordier, L., Lefèvre, L., Quantin, C., 2018. Tracing the sources of suspended sediment and particle-bound trace metal elements in an urban catchment coupling elemental and isotopic geochemistry, and fallout radionuclides. Environmental Science and Pollution Research. https:/ / doi.org/10.1007/s11356-018-2892-3.

Garcia Armisen, T., Servais, P., 2007. Respective contributions of point and non-point sources of E. coli and Enterococci in a large 
urbanised watershed (the Seine River, France). Journal of Environmental Management 82, 512-518.

Garnier, J., Billen, G., Servais, S., 1992a. Physiological characteristics and ecological role of small and large sized bacteria in a polluted river (Seine River, France). Archiv für Hydrobiologie Ergebnisse der Limnologie 37, 83-94.

Garnier, J., Chestérikoff, A., Testard, P., Garban, G., 1992b. Oligotrophication after a nutrient reduction in a shallow sand-pit lake (Créteil Lake, Paris suburbs, France): a case of rapid restoration. Annales de Limnologie 28, 253-262.

Garnier, J., Billen, G., 1993. Ecological interactions in a shallow sand-pit lake (Créteil Lake, France). A modelling approach. Nutrient dynamics and biological structure in shallow freshwater and brackish lakes. Hydrobiologia 275/276, 97-114.

Garnier, J., Billen, G., Coste, M., 1995. Seasonnal succession of diatoms and Chlorophyceae in the drainage network of the river Seine: observations and modelling. Limnology \& Oceanography 40, 750-765.

Garnier, J., Billen, G., Levassor, A., 1998. Réservoirs: fonctionnement et impacts éologiques. In: Meybeck, M., de Marsily, G., Fustec, E. (Eds.), La Seine en son Bassin. Elsevier, Paris, pp. 263-300 (Chapter 6).

Garnier, J., Leporcq, B., Sanchez, N., Philippon, 5.2., 1999. Biogeochemical budgets in three large reservoirs of the Seine basin (Marne, Seine \& Aube reservoirs). Biogeochemistry 47, 119-146.

Garnier, J., Billen, G., Sanchez, N., Leporcq, B., 2000. Ecological functioning of a large reservoir in the upstream basin of the river Seine (Marne reservoir, France). Regulated Rivers: Research \& Management 16, 51-71.

Garnier, J., Billen, G., Akopian, M., Némery, J., Pinault, S., Desruelle, M., Dufayt, O., Flipo, N., Even, S., Poulin, M., 2001. Développement des peuplements végétaux dans le Bassin de la Marne: Dynamique des nutriments et eutrophisation. Contrôle par les organismes filtreurs. RA Synthèse PIREN-Seine, 43pp.

Garnier, J., Billen, G., Hannon, E., Fonbonne, S., Videnina, Y., Soulie, M., 2002. Modeling transfer and retention of nutrients in the drainage network of the Danube River. Estuarine, Coastal and Shelf Science 54, 285-308.

Garnier, J., Némery, J., Billen, G., Théry, S., 2005. Nutrient dynamics and control of eutrophication in the Marne River system: modelling the role of exchangeable phosphorus. Journal of Hydrology 304, 397-412.

Garnier, J., Billen, G., 2007. Production vs. Respiration in river systems: an indicator of a "good ecological status" evaluation. The Science of the Total Environment 375, 110-124.

Garnier, J., Billen, G., Cébron, A., 2007. Modelling nitrogen transformations in the lower Seine river and estuary (France): impact of wastewater release on oxygenation and $\mathrm{N}_{2} \mathrm{O}$ emission. Hydrobiologia 588, 291-302.

Garnier, J., Beusen, A., Thieu, V., Billen, G., Bouwman, L., 2010. N:P:Si nutrient export ratios and ecological consequences in coastal seas evaluated by the ICEP approach. Special issue "past and future trends in nutrient export from global watersheds and impacts on water quality and eutrophication". Global Biogeochemical Cycles 24, GB0A05. https://doi.org/10.1029/2009GB003583.

Garnier, J., Passy, P., Thieu, V., Callens, J., Silvestre, M., Billen, G., 2014a. Fate of Nutrients in the Aquatic Continuum of the Seine River and its Estuary: Modelling the Impacts of Human Activity Changes. In: the Watershed Biogeochemical Dynamics at Large River-Coastal Interfaces: Linkages with Global Climate Change. Editors: T. S. Bianchi, M. A. Allison, and W.-J. Cai. Cambridge University Press. ISBN 978-1-107-20257-7. 671pp

Garnier, J., Billen, G., Vilain, G., Benoit, M., Passy, P., Tallec, G., Tournebize, J., Anglade, J., Billy, C., Mercier, B., Ansart, P., Sebilo, M., Kao, C., 2014b. Curative vs. preventive management of nitrogen transfers in rural areas: lessons from the case of the Orgeval watershed (Seine River basin, France). Journal of Environmental Management 144, 125-134. https://doi.org/10.1016/j.jenvman.2014.04.030.
Garnier, J., Lassaletta, L., Billen, G., Romero, E., Grizzetti, B., Némery, J., Le, Q.L.P., Pistocchi, C., Aissa-Grouz, N., Luu, M.T.N., Vilmin, L., Dorioz, J.-M., 2015. Phosphorus budget in the wateragro-food system at nested scales in two contrasted regions of the world (ASEAN-8 and EU-27). Global Biogeochemical Cycles. https: / / doi.org/10.1002/2015GB005147.

Garnier, J., Billen, B., 2016. Ecological processes and nutrient transfers from land to sea: a 25-year perspective on research and management of the Seine river system. In: Glibert, P.M., Kana, T.M. (Eds.), Aquatic Microbial Ecology and Biogeochemistry: A Dual Perspective. Springer International Publishing, Switzerland. https: / / doi.org/10.1007/978-3-319-30259-1_15, 2016.

Garnier, J., Anglade, J., Benoit, M., Billen, G., Puech, T., Ramarson, A., Passy, P., Silvestre, M., Lassaletta, L., Trommenschlager, J.-M., Schott, C., Tallec, G., 2016. Reconnecting crop and cattle farming to reduce nitrogen losses in river water of an intensive agricultural catchment (Seine basin, France). Environmental Science \& Policy 63, 76-90. https://doi.org/10.1016/j.envsci.2016.04.019.

Garnier, J., Ramarson, A., Thieu, V., Némery, J., Théry, S., Billen, G., Coynel, A., 2018a. How can we improve water quality when the Urban Waste Water directive has been complied (the case of the Lot River)? Environmental Science and Pollution Research. https:// doi.org/10.1007/s11356-018-1428-1.

Garnier, J., Ramarson, A., Billen, G., Théry, S., Thiéry, D., Thieu, V., Minaudo, C., Moatar, F., 2018b. Nutrient inputs and hydrology together determine biogeochemical status of the Loire River (France): current situation and possible future scenarios. The Science of the Total Environment 637-638, 609-624. https:// doi.org/10.1016/j.scitotenv.2018.05.045.

George, I., Crop, P., Servais, P., 2002. Fecal coliforms removal in wastewater treatment plants studied by plate counts and enzymatic methods. Water Research 36, 2607-2617.

George, I., Anzil, A., Servais, P., 2004. Quantification of fecal coliforms inputs to aquatic systems through soil leaching. Water Research 38, 611-618.

Gomez, E., Ledoux, E., Viennot, P., Mignolet, C., Benoît, M., Bornerand, C., Schott, C., Mary, B., Billen, G., Ducharne, A., Brunstein, D., 2003. Un outil de modélisation intégrée du transfert des nitrates sur un système hydrologique: application au bassin de la Seine. La Houille Blanche (3), 38-45, 2003.

Gosselain, V., Descy, J.-P., Everbeck, E., 1994. The phytoplankton community of the river Meuse, Belgium: seasonal dynamics (year 1992) and the possible incidence of zooplankton grazing. Hydrobiologia 289, 179-191.

Gosselain, V., Viroux, L., Descy, J.-P., 1998. Can a community of a small bodied grazers control phytoplankton in rivers? Freshwater Biology 39, 9-24.

Guerrini, M.-C., Mouchel, J.-M., Meybeck, M., Penven, M.-J., Hubert, G., Muxart, T., 1998. La Seine en son bassin. In: Meybeck, M., De Marsily, G., Fustec, F. (Eds.), Fonctionnement D'un Système Fluvial Anthropisé. Elsevier, Paris, pp. 29-75.

Guillocheau, F., Robin, C., Allemand, P., Bourquin, S., Brault, N., Dromart, G., Friedenberg, R., Garcia, J.-P., Gaulier, J.-M., Gaumet, F., Grosdoy, B., Hanot, F., Strat, P.L., Mettraux, M., Nalpas, T., Prijac, C., Rigoltet, C., Serrano, O., Grandjean, G., 2000. Meso-Cenozoic geodynamic evolution of the Paris Basin: 3D stratigraphic constraints. Geodinamica Acta 13, 189-245.

Guivarc'h-Blanchoud, H., 2001. Apports et transfert de pesticides en milieux agricole et urbain dans le bassin versant de la Marne: vers une évaluation globale. Thèse: Sciences et techniques de l'environnement. Ecole Nationale des Ponts et Chaussées, Paris, $87 \mathrm{pp}$.

Haycock, N.E., Pinay, G., Walker, C., 1993. Nitrogen retention in Phillips, J.D. 1993. Pre- and post-colonial sediment sources and storage river corridors: European perspectives, Ambio 22, 340-346. 
IFEN, 2007. Les pesticides dans les eaux, données 2005, numéro D9. pp. 39 http:/ / www.statistiques.developpement-durable.gouv. (Accessed 22 June 2011).

Tran, B.C., Teil, M.J., Blanchard, M., et al., 2015. BPA and phthalate fate in a sewage network and an elementary river of France. Influence of hydroclimatic conditions. Chemosphere 119, 43-51. https:// doi.org/10.1016/j.chemosphere.2014.04.036.

James, C., Fisher, J., Russel, V., Collings, S., Moss, B., 2005. Nitrate availability and hydrophyte species richness in shallow lakes. Freshwater Biology 50, 1049-1063. https://doi.org/10.1111/ j.1365-2427.2005.01375.x.

Khalanski, M., 1997. Conséquences industrielles et écologiques de l'introduction de nouvelles espèces dans les hydrosystèmes continentaux: La moule zébrée et autres espèces invasives. Bulletin Français de la Peche et de la Pisciculture 19, 1743-1762.

Labadie, P., Chevreuil, M., 2011a. Partitioning behaviour of perfluorinated alkyl contaminants between water, sediment and fish in the Orge River (nearby Paris, France) (vol 159, pg 391, 2011). Environmental Pollution 159, 1452-1453. https://doi.org/10.1016/ j.envpol.2011.01.021.

Labadie, P., Chevreuil, M., 2011b. Biogeochemical dynamics of perfluorinated alkyl acids and sulfonates in the River Seine (Paris, France) under contrasting hydrological conditions. Environmental Pollution 159, 3634-3639. https://doi.org/10.1016/j.envpol.2011.07.028.

Labarthe, B., 2016. Quantification des échanges nappe-rivière au sein de l'hydrosystème Seine par modélisation multi-échelle. MINES ParisTech. PSL Research University.

Labarthe, B., Pryet, A., Saleh, F., Akopian, M., Flipo, N., 2015. Distributed simulation of daily stream-aquifer exchanged fluxes in the Seine river basin at regional scale. Pages 261-265. In: Lollino, G., Arrattano, M., Rinaldi, M., Giustolisi, O., Marechal, J.-C., Grant, G.E. (Eds.), Engineering Geology for Society and Territory, vol. 3. Springer.

Lancelot, C., Thieu, V., Polard, A., Garnier, J., Billen, G., Hecq, W., Gypens, N., 2011. Ecological and economic effectiveness of nutrient reduction policies on coastal Phaeocystis colony blooms in the Southern North Sea: an integrated modeling approach. The Science of the Total Environment 409, 2179-2191. https://doi.org/ 10.1016/j.scitotenv.2011.02.023.

Le Cloarec, M.-F., Bonte, P., Lestel, L., Lefèvre, I., Ayrault, S., 2011. Sedimentary record of metal contamination in the Seine River during the last century. Physics and Chemistry of the Earth 36, 515-529. https://doi.org/10.1016/j.pce.2009.02.003.

Le Noë, J., Billen, G., Garnier, J., 2017. Nitrogen, phosphorus and carbon fluxes through the French Agro-Food System: an application of the GRAFS approach at the territorial scale. The Science of the Total Environment 586, 42-55. https: / / doi.org/10.1016/j.scitotenv.2017.02.040.

Le Noë, J., Garnier, J., Billen, G., 2018a. Phosphorus management in cropping systems of the Paris Basin: from farm to regional scale. Journal of Environmental Management 205, 18-28. https:// doi.org/10.1016/j.jenvman.2017.09.039.

Le Noë, J., Billen, G., Esculier, F., Garnier, J., 2018b. Long term socioecological trajectories of agro-food systems revealed by $\mathrm{N}$ and $\mathrm{P}$ flows: the case of French regions from 1852 to 2014. Agriculture, Ecosystems \& Environment 265, 132-143. https://doi.org/ 10.1016/j.agee.2018.06.006.

Le Pape, P., Ayrault, S., Quantin, C., 2012. Trace element behavior and partition versus urbanization gradient in urban Orge River, France. Journal of Hydrology 472-473, 99-110.

Le Pichon, C., Tales, E., Gorges, G., Baudry, J., Boet, P., 2016. Using a continuous riverscape survey to examine the effects of the spatial structure of functional habitats on fish distribution. Journal of Freshwater Ecology 31, 1-19.

Ledoux, E., 1980. Modélisation intégrée des écoulements de surface et des écoulements souterrains sur un bassin hydrologique. ENSMP, UPMC.
Ledoux, E., Girard, G., de Marsily, G., Villeneuve, J., Deschenes, J., 1989. Unsaturated flow in hydrologic modeling - theory and practice. Pages 435-454. In: Morel-Seytoux, H.J. (Ed.), Springer, NATO ASI Ser. CNorwell, Massachussett: Kluwer Academicy.

Ledoux, E., Gomez, E., Monget, J.-M., Viavattene, C., Viennot, P., Ducharne, A., Benoit, M., Mignolet, C., Schott, C., Mary, B., 2007. Agriculture and groundwater nitrate contamination in the Seine ba$\sin$. The STICS-MODCOU modelling chain. The Science of the Total Environment 375, 33-47.

Lestel, L., 2012. Non-ferrous metals ( $\mathrm{Pb}, \mathrm{Cu}, \mathrm{Zn}$ ) needs and city development: the Paris example (1815-2009). Regional Environmental Change 12, 311-323.

Lestel, L., Carré, C. (Eds.), 2017. Les rivières urbaines et leur pollution, Collection Indisciplines, Editions Quae.

Lestel, L., Meybeck, M., Thevenot, D.R., 2007. Metal contamination budget at the river basin scale: an original Flux-Flow Analysis (F2A) for the Seine River. Hydrology and Earth System Sciences Discussions 11, 1771-1781.

Lorgeoux, C., Moilleron, R., Gasperi, J., et al., 2016. Temporal trends of persistent organic pollutants in dated sediment cores: chemical fingerprinting of the anthropogenic impacts in the Seine River basin, Paris. The Science of the Total Environment 541, 1355-1363. https://doi.org/10.1016/j.scitotenv.2015.09.147.

Lucas, F., Thérial, C., Goncalves, A., Servais, P., Rocher, V., Mouchel, J.M., 2014. Variation of raw wastewater microbiological quality in dry and wet weather conditions. Environmental Science and Pollution Research 21, 5318-5328.

Malle, K.G., 1990. The pollution of the Rhine River with heavy metals. In: Heling, D., et al. (Eds.), Sediments and Environmental Geochemistry, pp. 279-290.

Marescaux, A., 2018. Carbon Cycling across the Human-Impacted Seine River Basin: From the Modelling of Carbon Dioxide Outgassing to the Assessment of Greenhouse Gas Emissions. Thèse de Doctorat, Ecole Doctorale 398 - Géosciences, ressources naturelles et environnement. Sorbonne Université, 253pp.

Marmonier, P., Archambaud, G., Belaidi, N., Bougon, N., Breil, P., Chauvet, E., Claret, C., Cornut, J., Datry, T., Dole-Olivier, M., Dumont, B., Flipo, N., Foulquier, A., Gérino, G.A.M., Julien, F.C., Martin Maazouzi, D., Mermillod-Blondin, F., Montuelle, B., Namour, P., Navel, S., Ombredane, D., Pelte, T., Piscart, C., Pusch, M., Stroffek, S., Robertson, A., Sanchez-Pérez, J., Sauvage, S., Taleb, A., Wantzen, M., Vervier, P., 2012. The role of organisms in hyporheic processes: gaps in current knowledge, needs for future research and applications. International Journal of Limnology 48, 253-266.

Martin, M.P., Wattenbach, M., Smith, P., Meersmans, J., Jolivet, C., Boulonne, L., Arrouays, D., 2011. Spatial distribution of soil organic carbon stocks in France. Biogeosciences 8, 1053-1065.

Marsily (de), G., Ledoux, E., Levassor, A., Poitrinal, D., Salem, A., 1978. Modelling of large multilayered aquifer systems: theory and applications. Journal of Hydrology 36, 1-34.

Massei, N., Laignel, B., Deloffre, J., Mesquita, J., Motelay, A., Lafite, R., Durand, A., 2010. Long-term hydrological changes of the Seine River flow (France) and their relation to the North Atlantic Oscillation over the period 1950-2008. International Journal of Climatology 30, 2146-2154.

Ménesguen, A., Desmit, 5.2., Dulière, V., Lacroix, G., Thouvenin, B., Thieu, V., Dussauze, M., 2018. How to avoid eutrophication in coastal seas? A new approach to derive river-specific combined nitrate and phosphate maximum concentrations. The Science of the Total Environment 628-629, 400-414.

Meybeck, M., de Marsily, G., Fustec, E., 1998. La Seine Dans Son Bassin. Fonctionnement Écologique D'un Système Fluvial. Elsevier, 749 pp.

Meybeck, M., Lestel, L., Bonté, P., Moilleron, R., Colin, J.L., Rousselot, O., Hervé, D., de Pontevès, C., Grosbois, C., Thévenot, D.R., 2007. 
Historical perspective of heavy metals contamination $(\mathrm{Cd}, \mathrm{Cr}, \mathrm{Cu}$, $\mathrm{Hg}, \mathrm{Pb}, \mathrm{Zn}$ ) in the Seine River basin (France) following a DPSIR approach (1950-2005). The Science of the Total Environment 375, 204-231.

Meybeck, M., 2013. Heavy metal contamination in rivers across the globe: an indicator of complex interactions between societies and catchments. Understanding Freshwater Quality Problems in a Changing World. International Association of Hydrological Science 361, 3-16.

Meybeck, M., Lestel, L., 2017. A western European River at the Anthropocene. In: Kelly, J.M., et al. (Eds.), Rivers of the Anthropocene, pp. 84-100.

Meybeck, M., Lestel, L., Winklhöfer, K., Vigano, L., Evrard, O., Bonté, P., 2017. Un exemple de trajectoire environnementale: la contamination méttallique de la Seine, la Spree, la Senne et le Lambro (1950-2010). In: Lestel, L., Carré, C. (Eds.), Les Rivières Urbaines et Leur Pollution, Quae, Paris, pp. 229-242.

Meybeck, M., Lestel, L., Carré, C., Bouleau, G., Garnier, J., Mouchel, J.M., 2018. Trajectories of river chemical quality issues over the longue durée: the Seine river (1900s-2010). Environmental Science and Pollution Research 25, 23468. https: / / doi.org/10.1007/ s11356-016-7124-0.

Mignolet, C., Schott, C., Benoit, M., 2007. Spatial dynamics of farming practices in the Seine basin: methods for agronomic approaches on a regional scale. The Science of the Total Environment 375, 13-32.

Mons, C., Dumètre, A., Gosselin, S., Galliot, C., Moulin, L., 2009. Monitoring of Cryptosporidium and Giardia river contamination in Paris area. Water Research 43, 211-217.

Mouchel, J.M., Boët, P., Hubert, G., Guerrini, M.C., 1998. Un bassin et des hommes: une histoire tourmentée. In: Meybeck, M., de Marsily, G., Fustec, E. (Eds.), La Seine en son Bassin. Elsevier, Paris, pp. 77-125 (Chapter 2).

Müller, G., Förstner, U., 1973. Heavy Metal Accumulation in River Sediments: The Response to Environmental Pollution. Elsevier.

Newcomer, M.E., Hubbard, S.S., Fleckenstein, J.H., Maier, U., Schmidt, C., Thullner, M., Ulrich, C., Flipo, N., Rubin, Y., 2018. Influence of hydrological perturbations and riverbed sediment characteristics on hyporheic zone respiration of $\mathrm{CO}_{2}$ and $\mathrm{N}_{2}$. Journal of Geophysical Research: Biogeosciences 123, 1-21.

Nicola, L., Schott, C., Mignolet, C., 2011. Dynamique de changement des pratiques agricoles dans le bassin versant de l'Orgeval et création de la base de données APOCA (Agricultural Practices of the Orgeval Catchment Area). Annual PIREN Seine report, 49pp.

Passerat, J., Ouattara, K., Mouchel, J.M., Rocher, V., Servais, P., 2011. Impact of an intense combined sewer overflow event on the microbiological water quality of the Seine River. Water Research 45, 893-903.

Passy, P., Gypens, N., Billen, G., Garnier, J., Lancelot, C., Thieu, V., Rousseau, V., Callens, J., 2013. A Model reconstruction of riverine nutrient fluxes and eutrophication in the Belgian Coastal Zone since 1984. Journal of Marine Systems 128, 106-122. https:// doi.org/10.1016/j.jmarsys.2013.05.005.

Passy, P., Le Gendre, R., Garnier, J., Cugier, P., Callens, J., Paris, F., Billen, G., Riou, P., Romero, E., 2016. Eutrophication modelling chain for improved management strategies to prevent algal blooms in the Seine Bight. Marine Ecology Progress Series 543, 107-125. https: / / doi.org/10.3354/meps11533.

Perrier, C., Evanno, G., Belliard, J., Guyomard, R., Bagliniere, J.L., 2010. Natural recolonization of the Seine River by Atlantic salmon (Salmo salar) of multiple origins. Canadian Journal of Fisheries and Aquatic Sciences 67, 1-4.

Prevost, B., Lucas, F.S., Goncalves, A., Richard, F., Moulin, L., Wurtzer, S., 2015. Large scale survey of enteric viruses in river and waste water underlines the health status of the local population. Environment International 79, 383-396.
Pryet, A., Labarthe, B., Saleh, F., Akopian, M., Flipo, N., 2015. Reporting of stream-aquifer flow distribution at the regional scale with a distributed process-based model. Water Resources Management 29, 139-159.

Quintana-Seguí, P., Moigne, P.L., Durand, Y., Martin, E., Habets, F., Baillon, M., Canellas, C., Franchisteguy, L., Morel, S., 2008. Analysis of near-surface atmospheric variables: validation of the SAFRAN analysis over France. Journal of Applied Meteorology and Climatology 47, 92-107.

Raimonet, M., Vilmin, L., Flipo, N., Rocher, V., Laverman, A.M., 2015. Modelling the fate of nitrite in an urbanized river using experimentally obtained nitrifier growth parameters. Water Research 73, 373-387.

Raimonet, M., Thieu, V., Silvestre, M., Oudin, L., Rabouille, C., Vautard, R., Garnier, J., 2018. Coastal eutrophication potential under future climate change: a landward perspective. Frontiers in Marine Science, Section Marine Biogeochemistry 5, 136. https:// doi.org/10.3389/fmars.2018.00136.

Redfield, A.C., Ketchum, B.H., Richards, F.A., 1963. The influence of organisms on the composition of sea-water. In: Hill, M.N. (Ed.), The Sea. John Wiley, New York, pp. 12-37.

Reynolds, C.S., 1984. Phytoplankton periodicity: the interaction of form, function and environmental variability. Freshwater Biology 14, 111-142.

Reynolds, C.S., Descy, J.P., Padisak, J., 1994. Are phytoplankton dynamics in rivers so different from those in shallow lakes? Hydrobiologia 289, 1-7.

Rocher, V., Azimi, S., Bernier, J., Guérin-Rechdaoui, S., Mailler, R., Pichon, S., Gonçalvez, A., Rousselot, O., Mouchel, J.M., Lucas, F., 2017. Qualité bactériologique des eaux en agglomération parisienne. Des eaux usées aux eaux de Seine. Edition Johanet, 94pp.

Rocher, V., Azimi, S., 2017. Evolution de la qualité de la Seine en lien avec les progrès de l'assainissement. Editions Johannet, Paris, 76 pp.

Rockström, J., Falkenmark, M., Allan, T., Folke, C., Gordon, L., Jägerskog, A., Kummu, M., Lannerstad, M., Meybeck, M., Molden, D., Postel, S., Savenije, H.H.G., Svedin, U., Turton, A., Varis, O., 2014. The unfolding water drama in the Anthropocene: towards a resilience-based perspective on water for global sustainability. Ecohydrology 7, 1249-1261.

Romero, E., Garnier, J., Lassaletta, L., Billen, G., Le Gendre, R., Riou, P., Cugier, P., 2013. Large-scale patterns of river inputs in SW Europe: seasonal and interannual variations and potential eutrophication effects at the coastal zone. Biogeochemistry 113, 481-505. https:/ / doi.org/10.1007/s10533-012-9778-0.

Roy, M.L., Le Pichon, C., 2017. Modelling functional fish habitat connectivity in rivers: a case study for prioritizing restoration actions targeting brown trout. Aquatic Conservation: Marine and Freshwater Ecosystems 27, 927-937.

Ruelland, D., Billen, G., Brunstein, D., Garnier, J., 2007. SENEQUE 3: a GIS interface to the RIVERSTRAHLER model of the biogeochemical functioning of river systems. The Science of the Total Environment 375, 257-273.

Saleh, F., Flipo, N., Habets, F., Ducharne, A., Oudin, L., Viennot, P., Ledoux, E., 2011. Modeling the impact of in-stream water level fluctuations on stream-aquifer interactions at the regional scale. Journal of Hydrology 400, 490-500.

Salminen, R., Batista, M.J., Bidovec, M., Demetriades, A., De Vivo, B., De Vos, W., et al., 2005. Geochemical Atlas of Europe, Part 1, Background Information, Methodology and Maps. Geological survey of Finland, ISBN 951-690-921-3.

Sauvegrain, P., 1981. Les micropolluants organiques dans les eaux superficielles continentales : les pesticides organochlorés et autres. Association Française pour l'étude des eaux. Report. 225pp. 
Schanen, O., 1998. Analyse et modélisation de l'impact hydrodynamique et biogéochimique des lacs de gravières sur la nappe alluviale du val de Seine. Ph-D, University Pierre and Marie Curie. 365 pp.

Schott, C., Mignolet, C., Benoît, M., 2004. Modélisation des pratiques phytosanitaires sur le bassin de la Vesle : le cas du désherbage chimique de la vigne et du maïs de 1970 à nos jours. Annual PIRENSeine report.

Sebilo, M., Billen, G., Grably, M., Mariotti, A., 2003. Isotopic composition of nitrate-nitrogen as a marker of riparian and benthic denitrification at the scale of the whole Seine River system. Biogeochemistry 63, 35-51.

Servais, P., Garnier, J., 1993. Contribution of heterotrophic bacterial production to the carbon budget of the River Seine (France). Microbial Ecology 25, 19-33.

Servais, P., Barillier, A., Garnier, J., 1995. Determination of the biodegradable fraction of dissolved and particulate organic carbon. Annales de Limnologie 31, 75-80.

Servais, P., Garcia-Armisen, T., George, I., Billen, G., 2007a. Fecal bacteria in the rivers of the Seine drainage network: source, fate and modeling. The Science of the Total Environment 375, $152-167$.

Servais, P., Billen, G., Goncalvez, A., Garcia-Armisen, T., 2007b. Modelling microbiological water quality in the Seine river drainage network: past, present and future situations. Hydrology and Earth System Sciences 11, 1581-1592.

Sferratore, A., Garnier, J., Billen, G., Conley, D., Pinault, S., 2006. Silica diffuse and point sources in the Seine watershed. Environmental Science and Technology 40, 6630-6635.

Strahler, A.H., 1957. Quantitative analysis of whatershed geomophology. Transactions - American Geophysical Union 38, 913-920.

Streeter, H.W., Phelps, E.B., 1925. A Study of the Pollution and Natural Purification of the Ohio River. III. Factors Concerned in the Phenomena of Oxidation and Reaeration. Public Health Bulletin no. 146, Reprinted by U.S. Department of Health, Education and Welfare, Public Health Service. B001BP4GZI, 1958. http://dspace. udel.edu:8080/dspace/bitstream/handle/19716/1590/C\% 26EE148.pdf? sequence $=2$.

Tales, E., Berrebi, R., 2007. Controls of local young-of-the-year fish species richness in flood plain water bodies: potential effects of habitat heterogeneity, productivity and colonisation-extinction events. Ecology of Freshwater Fish 16, 144-154.

Tamtam, F., Mercier, F., Le Bot, B., et al., 2008. Occurrence and fate of antibiotics in the Seine River in various hydrological conditions. The Science of the Total Environment 393, 84-95. https:// doi.org/10.1016/j.scitotenv.2007.12.009.

Teil, M.J., Tlili, K., Blanchard, M., et al., 2012. Occurrence of polybrominated diphenyl ethers, polychlorinated biphenyls, and phthalates in freshwater fish from the Orge River (Ile-de France). Archives of Environmental Contamination and Toxicology 63, 101-113. https: / / doi.org/10.1007/s00244-011-9746-z.

Testard, P., 1990. Eléments d'écologie du Lamellibranche invasif Dreissena polymorpha Pallas. Etude de la dispersion des larves en région parisienne et de leur fixation. State Dissertation. University Paris VI, Paris.

Testard, P., 1992. L'envahissement des milieux aquatiques par la Dreissène. Inconvénients, risques pour les réseaux de distribution.
Évolution de la qualité de l'eau dans les réseaux de distribution. Technique Sciences Méthodes L'eau 7-8, 369-373.

Thévenot, D., Moilleron, R., Lestel, L., Gromaire, M.C., Rocher, V., Cambier, P., Bonté, P., Colin, J.L., de Pontevès, C., Meybeck, M., 2007. Critical budget of metal sources and pathways in the Seine river basin (1994-2003) for $\mathrm{Cd}, \mathrm{Cr}, \mathrm{Cu}, \mathrm{Hg}, \mathrm{Ni}, \mathrm{Pb}$ and $\mathrm{Zn}$. The Science of the Total Environment 375, 180-203.

Thieu, V., Billen, G., Garnier, J., 2009. Nutrient transfer in three contrasting NW European watersheds: the Seine, Somme, and Scheldt Rivers. A comparative application of the Seneque/Riverstrahler model. Water Research 43, 1740-1754.

Thouvenot, M., Billen, G., Garnier, J., 2007. Modelling nutrient exchange at the sediment - water interface of River Systems. Journal of Hydrology 341, 55-78.

Thouvenot-Korppoo, M., Billen, G., Garnier, J., 2009. Modelling benthic denitrification processes over a whole drainage network. Journal of Hydrology 379, 239-250.

Tlili, K., Labadie, P., Alliot, F., et al., 2012. Influence of hydrological parameters on organohalogenated micropollutant (polybrominated diphenyl ethers and polychlorinated biphenyls) behaviour in the seine (France). Archives of Environmental Contamination and Toxicology 62, 570-578. https://doi.org/10.1007/s00244-011-9734-3.

UIPP, 2010. Union des Industries de la Protection des Plantes. Rapport d'activité. UIPP, 2010/2011, 32 pp. http:/ / www.uipp.org/content/ download/71/273/.../UIPP_RA_2011_V10.pdf.

Vannote, R.L., Minshall, G.W., Cummins, K.W., Sedell, J.R., Cushing, C.E., 1980. The river continuum concept. Canadian Journal of Fisheries and Aquatic Sciences 37, 130-137.

Vidal, J.-P., Martin, E., Franchistéguy, L., Habets, F., Soubeyroux, J.M., Blanchard, M., Baillon, M., 2010. Multilevel and multiscale drought reanalysis over France with the Safran-Isba-Modcou hydrometeorological suite. Hydrology and Earth System Sciences $14,459-478$

Vilmin, L., Flipo, N., de Fouquet, C., Poulin, M., 2015a. Pluri-annual sediment budget in a navigated river system: the Seine River (France). The Science of the Total Environment 502, 48-59.

Vilmin, L., Aissa-Grouz, N., Garnier, J., Billen, G., Mouchel, J.M., Poulin, M., Flipo, N., 2015b. Impact of hydro-sedimentary processes on the dynamics of soluble reactive phosphorus in the Seine River. Biogeochemistry 122, 229-251.

Vilmin, L., Flipo, N., Escoffier, N., Rocher, V., Groleau, A., 2016. Carbon fate in a large temperate human-impacted river system: focus on benthic dynamics. Global Biogeochemical Cycles 30, 1086-1104.

Vilmin, L., Flipo, N., Escoffier, N., Groleau, A., 2018. Estimation of the water quality of a large urbanized river as defined by the European WFD: what is the optimal sampling frequency? Environmental Science and Pollution Research 25, 23485. https://doi.org/10.1007/ s11356-016-7109-z.

Vought, L.B.M., Dahl, J., Pedersen, C.L., Lacoursière, J.O., 1994. Nutrient retention in riparian ecotones. Ambio 23, 342-347.

Ward, J.V., Stanford, J.A., 1983. The serial discontinuity concept of lotic ecosystems. In: Fontaine, T.D., Bartell, S.M. (Eds.), Dynamics of Lotic Ecosystems. Ann Arbor Science Publishers, Ann Arbor, MI, pp. $29-42$.

Zwolsman, J.J.G., van Eck, G.T.M., 1999. Geochemistry of major elements and trace metals in suspended matter of the Scheldt estuary, southwest Netherlands. Marine Chemistry 66, 91-111. 